The Quality of Our Nation's Waters

\title{
Water Quality in the Upper Floridan Aquifer and Overlying Surficial Aquifers, Southeastern United States, 1993-2010
}

National Water-Quality Assessment Program

Circular 1355

U.S. Department of the Interior U.S. Geological Survey 
Cover. Wekiwa Spring, Wekiwa Springs State Park, Orange County, Florida.

Photographs in this report are by Alan M. Cressler, U.S. Geological Survey, unless otherwise indicated. 
The Quality of Our Nation's Waters

\section{Water Quality in the Upper Floridan Aquifer and Overlying Surficial Aquifers, Southeastern United States, 1993-2010}

By Marian P. Berndt, Brian G. Katz, James A. Kingsbury, and Christy A. Crandall

National Water-Quality Assessment Program

Circular 1355 


\title{
U.S. Department of the Interior SALLY JEWELL, Secretary
}

\section{U.S. Geological Survey Suzette M. Kimball, Acting Director}

\author{
U.S. Geological Survey, Reston, Virginia: 2014
}

For more information on the USGS — the Federal source for science about the Earth, its natural and living resources, natural hazards, and the environment-visit http://www.usgs.gov or call 1-888-ASK-USGS.

For an overview of USGS information products, including maps, imagery, and publications, visit $h$ ttp://www.usgs.gov/pubprod

To order this and other USGS information products, visit http://store.usgs.gov

Any use of trade, firm, or product names is for descriptive purposes only and does not imply endorsement by the U.S. Government.

Although this information product, for the most part, is in the public domain, it also may contain copyrighted materials as noted in the text. Permission to reproduce copyrighted items must be secured from the copyright owner.

Suggested citation:

Berndt, M.P., Katz, B.G., Kingsbury, J.A., and Crandall, C.A., 2014, The quality of our Nation's waters-Water quality in the Upper Floridan aquifer and overlying surficial aquifers, southeastern United States, 1993-2010: U.S. Geological Survey Circular 1355, 72 p., http://dx.doi.org/10.3133/cir1355.

\section{Library of Congress Cataloging-in-Publication Data}

Berndt, Marian P.

The quality of our nation's waters---water quality in the upper Floridan aquifer and overlying surficial aquifers, Southeastern United States, 1993--2010 / by Marian P. Berndt, Brian G. Katz, James A. Kingsbury, and Christy A. Crandall, National Water-Quality Assessment Program.

pages cm. -- (Circular, ISSN 1067-084X; 1355)

Includes bibliographical references.

ISBN 978-1-4113-3753-4

1. Water quality--Southern States. 2. Groundwater--Southern States--Quality. 3. Drinking water--Contamination-Southern States. 4. Floridan Aquifer. I. Katz, Brian G. II. Kingsbury, James A. III. Crandall, Christy A. IV. Geological Survey (U.S.) V. Title. VI. Series: U.S. Geological Survey circular ; 1355.

TD223.5.B47 2014

363.739'420975--dc23

2014012827

ISSN 1067-084X (print) ISSN 2330-5703 (online) ISBN 978-1-4113-3753-4 


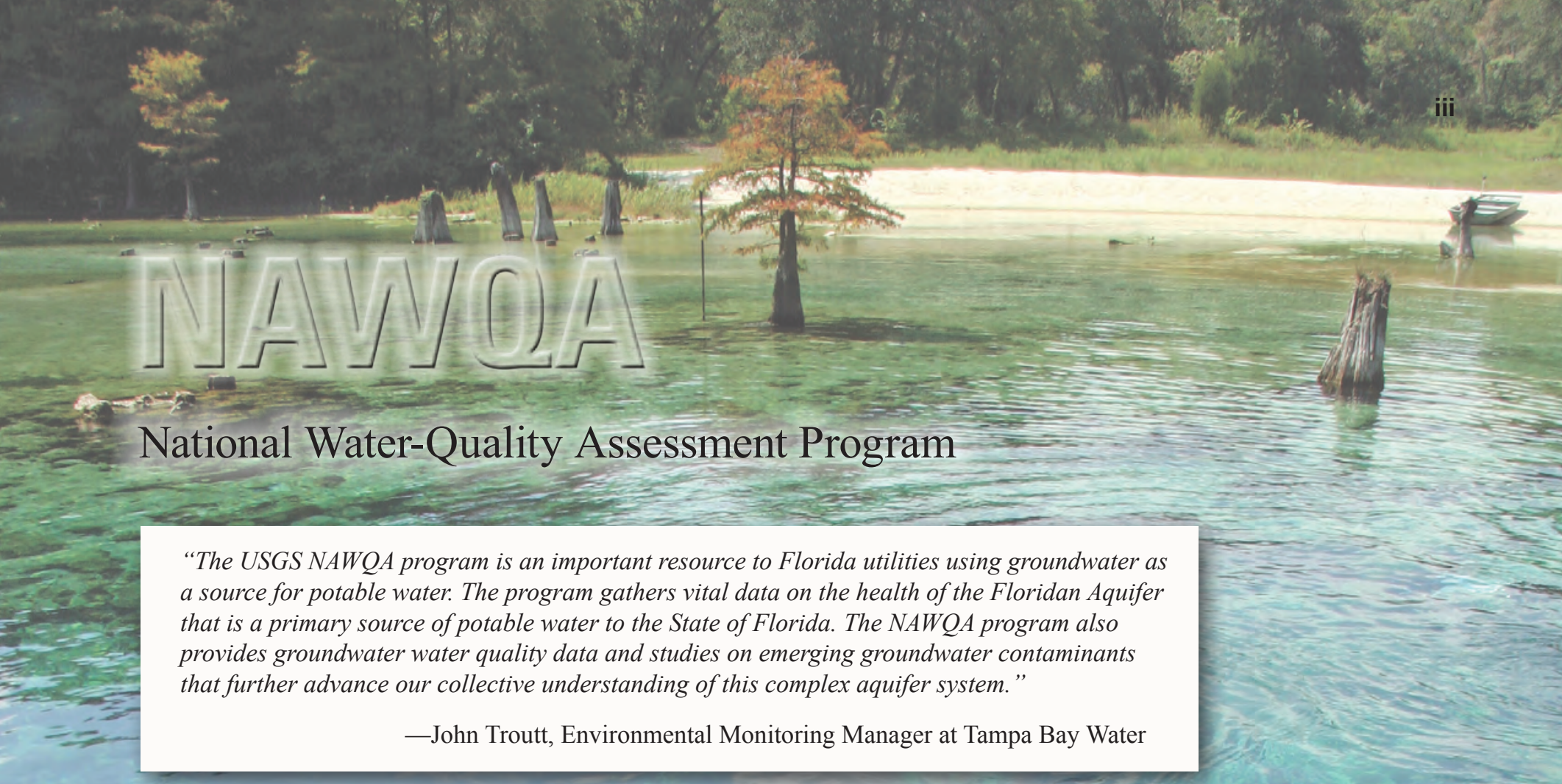

"Monitoring water quality is necessary to gauge the effectiveness of management practices that impact water quality. The USGS NAWQA studies allow us to be informed of water quality issues in other States and adjust our water quality monitoring needs accordingly. The NAWQA data within our State provides useful water-quality information that helps us to better understand our complex aquifer systems."

-Richard Hicks, Florida Department of Environmental Protection, Ground Water Management Section 


\section{Foreword}

The United States has made major investments in assessing, managing, regulating, and conserving natural resources, such as water and a variety of ecosystems. Sustaining the quality of the Nation's water resources and the health of our diverse ecosystems depends on the availability of sound water-resources data and information to develop effective, science-based policies. Effective management of water resources also brings more certainty and efficiency to important economic sectors. Taken together, these actions lead to immediate and long-term economic, social, and environmental benefits that make a difference to the lives of millions of people (http://water.usgs.gov/nawqa/applications/).

Two decades ago, Congress established the U.S. Geological Survey's National Water-Quality Assessment (NAWQA) Program to meet this need. Since then, NAWQA has served as a primary source of nationally consistent information on the quality of the Nation's streams and groundwater, on ways in which water quality changes over time, and on the natural features and human activities affecting the quality of streams and groundwater. Objective and reliable data, systematic scientific studies, and models are used to characterize where, when, and why the Nation's water quality is degraded — and what can be done to improve and protect the water for human and ecosystem needs. This information is critical to our future because the Nation faces an increasingly complex and growing need for clean water to support people, economic growth, and healthy ecosystems. For example, NAWQA findings for public-supply wells, which provide water to about 105 million people, showed that 22 percent of source-water samples contained at least one contaminant at levels of potential health concern. Similarly, 23 percent of samples from domestic (or privately owned) wells, which supply untreated water to an additional 43 million people, also had contaminant levels of potential concern.

This report is one of a collection of publications that describe water-quality conditions in selected Principal Aquifers of the United States (http://water.usgs.gov/nawqa/studies/praq/. The collection is part of the series "The Quality of Our Nation's Waters," which describes major findings of the NAWQA Program on water-quality issues of regional and national concern and which provides science-based information for assessing and managing the quality of our groundwater resources. Other reports in this series focus on occurrence and distribution of nutrients, pesticides, and volatile organic compounds in streams and groundwater, the effects of contaminants and streamflow alteration on the condition of aquatic communities in streams, and the quality of untreated water from private domestic and public-supply wells. Each report builds toward a more comprehensive understanding of the quality of regional and national water resources (http://water.usgs.gov/nawqa/

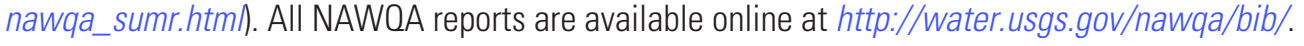

The information in this series primarily is intended for those interested or involved in resource management and protection, conservation, regulation, and policymaking at regional and national levels. In addition, the information should be of interest to those at a local level who wish to know more about the general quality of streams and groundwater in areas near where they live and how that quality compares with other areas across the Nation. We hope this publication will provide you with insights and information to meet your needs and will foster increased citizen awareness and involvement in the protection and restoration of our Nation's waters.

Jerad Bales

Acting Associate Director for Water

U.S. Geological Survey 


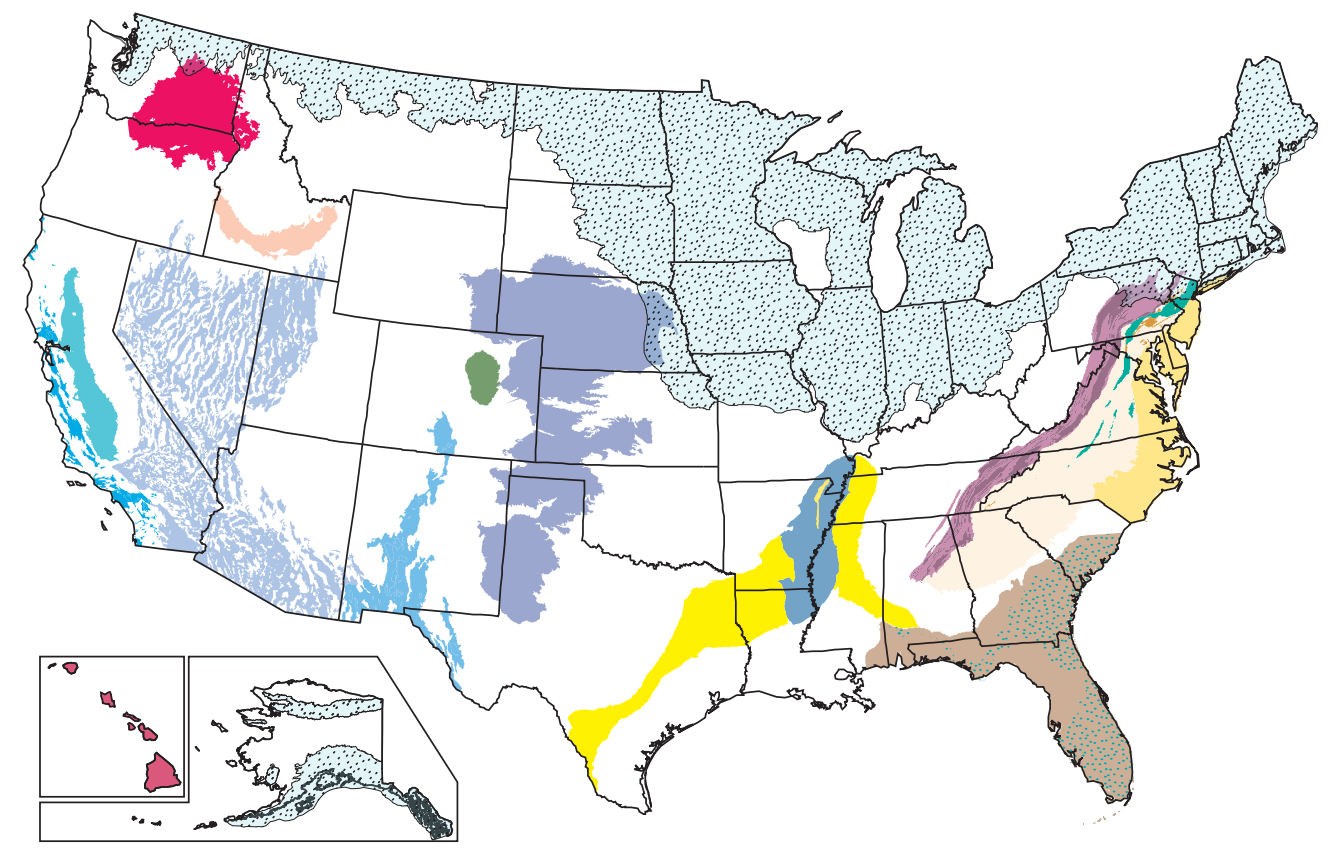

Principal Aquifers and Water-Quality Summary Reports

National summary of groundwater quality in Principal Aquifers-Circular 1360

High Plains aquifer system-Circular 1337

Glacial aquifer system-Circular 1352

Northern Atlantic Coastal Plain surficial aquifer system-Circular 1353

Piedmont, Blue Ridge, and Valley and Ridge aquifers-Circular 1354

Piedmont and Blue Ridge carbonate-rock aquifers

Piedmont and Blue Ridge crystalline-rock aquifers

Valley and Ridge siliciclasticrock aquifers

Valley and Ridge carbonaterock aquifers

Early Mesozoic basin aquifers

Upper Floridan aquifer and overlying surficial aquifers-Circular 1355
Mississippi embayment-Texas coastal uplands aquifer system - Circular 1356

Mississippi River Valley alluvial aquifer

Denver Basin aquifer system - Circular 1357

Southwest Principal Aquifers-Circular 1358

California Coastal Basin aquifers

Central Valley aquifer system

Basin and Range basin-fill aquifers

Rio Grande aquifer system

Western Volcanics-Circular 1359

Hawaiian volcanic-rock aquifers

Snake River Plain basin-fill and basaltic-rock aquifers

Columbia Plateau basin-fill and basaltic-rock aquifers 


\section{Contents}

Chapter 1: Overview of Major Findings and Implications ....................................................1

Chapter 2: NAWQA Approach to Assessing Groundwater Quality .....................................7

Chapter 3: Environmental and Hydrogeologic Setting...................................................15

Chapter 4: Natural Processes and Human Activities That Affect Groundwater Quality .....................................................................................25

Chapter 5: Quality of the Groundwater Resource Used for Drinking ...............................29

Chapter 6: Understanding Where and Why Key Contaminants Occur

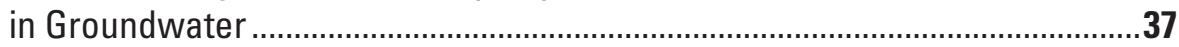

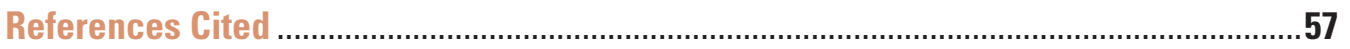

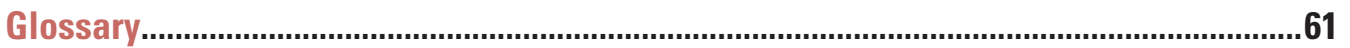

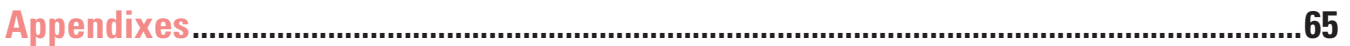




\section{Introduction to This Report}

This report contains the major findings of a regional assessment of water quality in the Upper Floridan aquifer of the Floridan aquifer system and overlying surficial aquifers in the Southeastern United States. It is one of a series of reports by the U.S. Geological Survey (USGS) National Water-Quality Assessment (NAWQA) Program that present major findings for Principal Aquifers, other aquifers, and major river basins across the Nation. In these reports, water quality is discussed in terms of local, State, regional, and national issues. Conditions in these aquifers are compared to conditions found elsewhere and to selected national benchmarks, such as those for drinking-water quality.

This report is intended for individuals working with water-resource issues in local, State, or Federal agencies, universities, public interest groups, or the private sector. The information will be useful in addressing current issues, such as drinking-water quality, source-water protection, and monitoring and sampling strategies. This report also will be useful for individuals who wish to know more about the quality of groundwater in areas near where they live and how that quality of water compares to the quality of water in other areas across the region and the Nation.

Water-quality conditions in the Upper Floridan aquifer of the Floridan aquifer system and overlying surficial aquifers summarized in this report are discussed in greater detail in other reports listed in the references. Detailed technical information, data and analyses, sample collection and analytical methodology, models, graphs, and maps that support the findings presented in this report in addition to reports in this series from other Principal Aquifers can be accessed from the national NAWQA Web site (http://water.usgs.gov/nawqa/). 
Companion studies of these aquifers are discussed in the following reports.

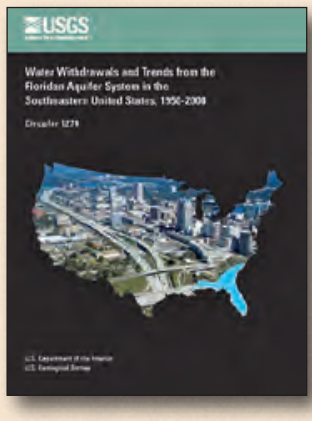

Water withdrawals and trends from the Floridan aquifer system in the Southeastern United States, 1950-2000

U.S. Geological Survey Circular 1278

By Richard L. Marella and Marian P. Berndt

(Also available at $h$ ttp://pubs.usgs.gov/circ/2005/1278/

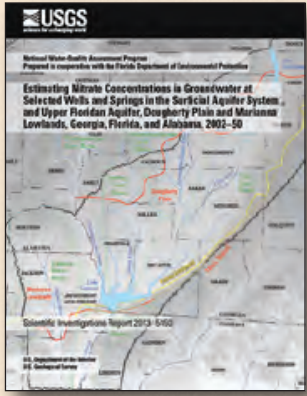

Estimating nitrate concentrations in groundwater at selected wells and springs in the surficial aquifer system and Upper Floridan aquifer, Dougherty Plain and Marianna Lowlands, Georgia, Florida, and Alabama, 2002-50

U.S. Geological Survey Scientific Investigations Report 2013-5150

By Christy A. Crandall, Brian G. Katz, and Marian P. Berndt

(Also available at http://pubs.usgs.gov/sir/2013/5150/

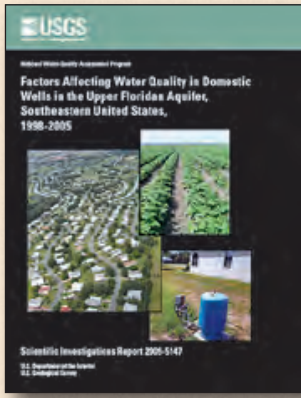

Factors affecting water quality in domestic wells in the Upper Floridan aquifer, Southeastern United States, 1998-2005

U.S. Geological Survey Scientific Investigations Report 2009-5147

By Marian P. Berndt and Christy A. Crandall

(Also available at http://pubs.usgs.gov/sir/2009/5147/ 


\section{Chapter 1: Overview of Major Findings and Implications}

$\mathrm{T}$

The Floridan aquifer system supplies drinking water to about 10 million people in the southeastern United States. Withdrawals of water from this highly productive carbonate aquifer system have increased by more than 500 percent since 1950 , as population, tourism, and agricultural production in the region have increased. Groundwater from the Floridan aquifer system is important to the economies of the States that overlie it - as a source of water for agriculture and as the source of large, clear-water springs that are recreational and tourist destinations.

The U.S. Geological Survey (USGS) assessment of water-quality conditions of the Upper Floridan and surficial aquifers for the period 1993-2010 provides a regional assessment of water quality in these important aquifers. This assessment describes where and why specific groundwater-quality conditions occur in different parts of the region and how contaminants - from both geologic and human sources-move into and through the groundwater system. A better understanding of the factors that affect water quality supports effective waterresources management for human and ecological health and for the sustainability of this critical resource as the population and the need for water increase.
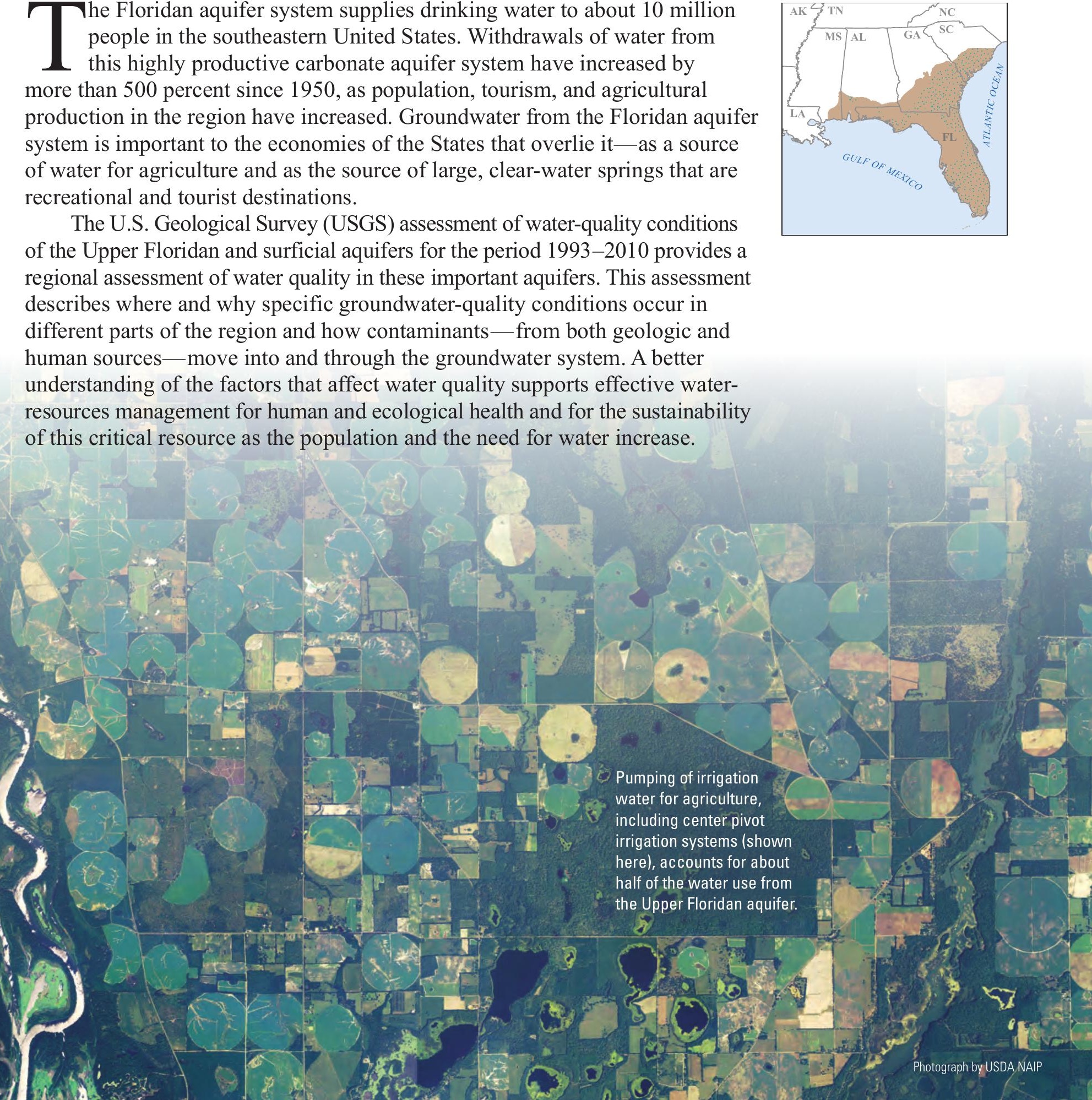


\section{Overview of Major Findings and Implications for the Upper}

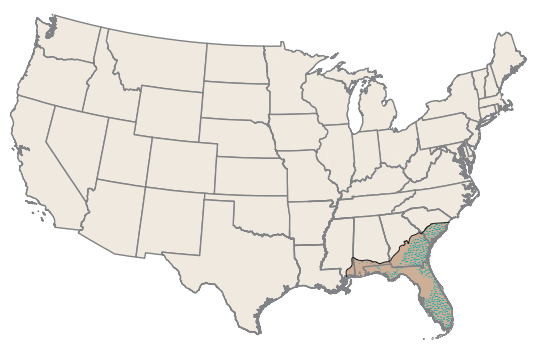

About 10 million people rely on groundwater from the Upper Floridan and surficial aquifers for drinking water. The Upper Floridan aquifer also is of primary importance to the region as a source of water for irrigation and as a source of crystal clear water that discharges to springs and streams providing recreational and tourist destinations and unique aquatic habitats. The reliance of the region on the Upper Floridan aquifer for drinking water and for the tourism and agricultural economies highlights the importance of long-term management to sustain the availability and quality of these resources.

\section{The quality of groundwater in the Upper Floridan aquifer} is among the best in the Nation

Fewer than 1 in 20 water samples collected from drinking-water wells in the Upper Floridan aquifer contained a constituent at a concentration that exceeded a human-health benchmark. Among all constituents measured, radon exceeded its human-health benchmark (proposed alternative Maximum Contaminant Level of 4,000 picocuries per liter) most frequently. See page 29.

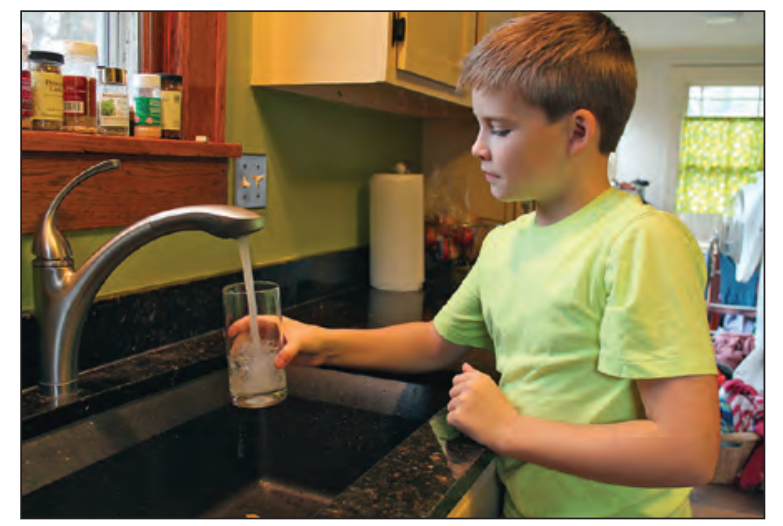

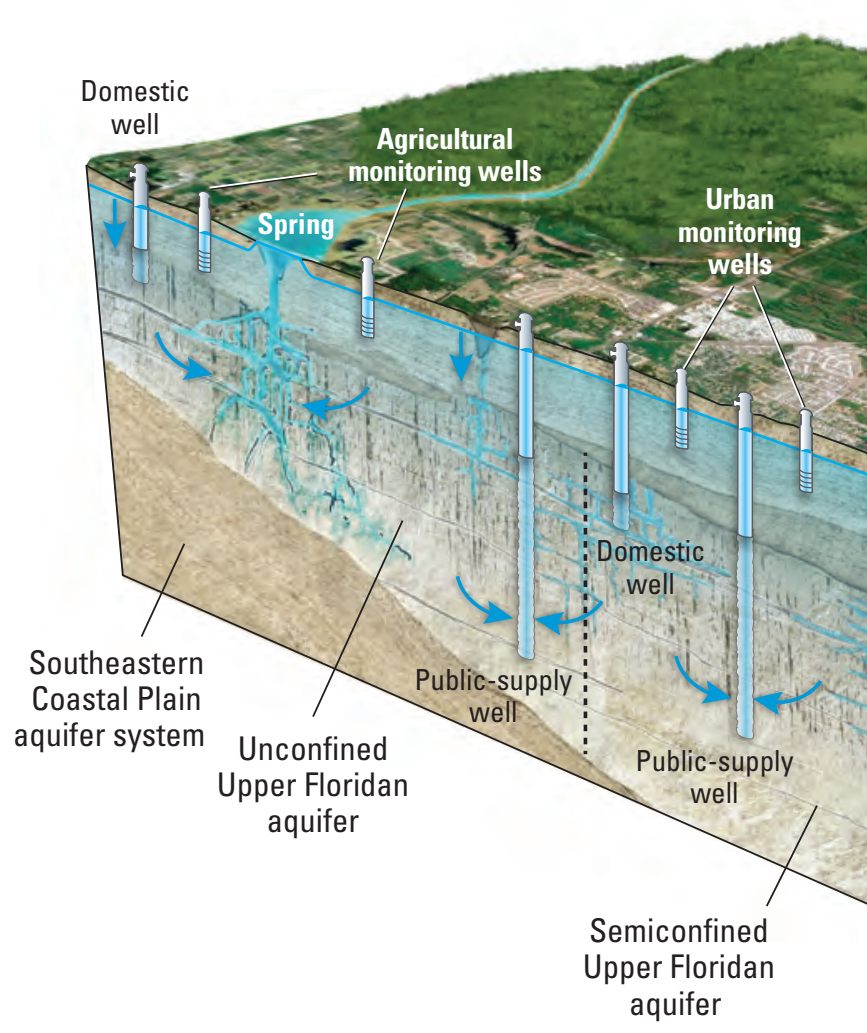

\section{Nitrate concentrations commonly exceed the criterion for water discharging from springs}

Somewhat surprisingly, nitrate concentrations in the Upper Floridan aquifer in many areas have remained relatively low, despite widespread sources of nitrogen. Of the 252 samples from the Upper Floridan aquifer, only one sample had a nitrate concentration greater than the Maximum Contaminant Level of 10 milligrams per liter $(\mathrm{mg} / \mathrm{L})$ as nitrogen. Nearly half of the samples, however, had nitrate concentrations greater than the recently adopted criterion of $0.35 \mathrm{mg} / \mathrm{L}$. Although these concentrations are not a concern for human health, even small increases in groundwater nitrate concentrations might have adverse effects on the water quality and aquatic species that rely on spring flows for habitat. See page 43 .

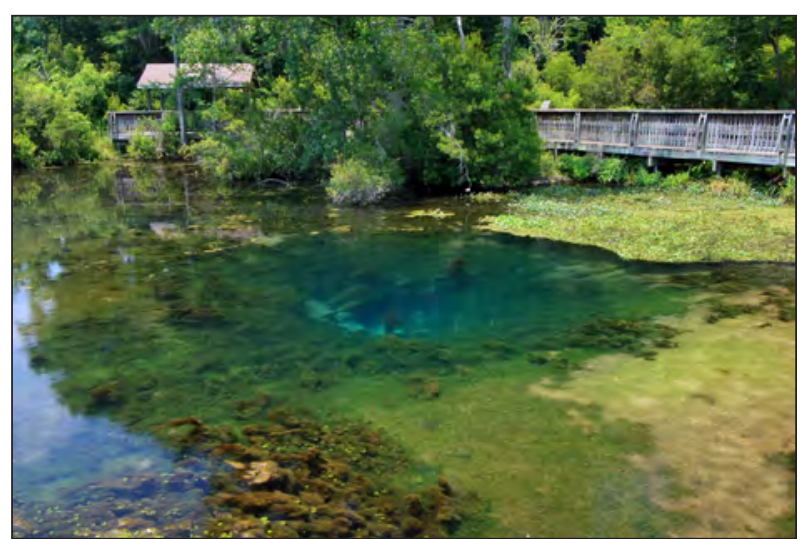




\section{Floridan Aquifer and Overlying Surficial Aquifers}

\section{The absence of an upper confining layer and the presence of karst features increase the vulnerability}

of parts of the Upper Floridan aquifer to contamination from human activities

Karst features, such as sinkholes and large conduits, have developed in those areas where the Upper Floridan aquifer is unconfined and rain that infiltrates the soil and recharges the aquifer can dissolve away the carbonate rock. Karst features allow contaminants, such as pesticides, to move rapidly from the land surface into the aquifer. These features are common where the Upper Floridan aquifer is unconfined in southwestern Georgia and north-central Florida - areas where agricultural activities are concentrated. See pages 20-21, 39, and 44.
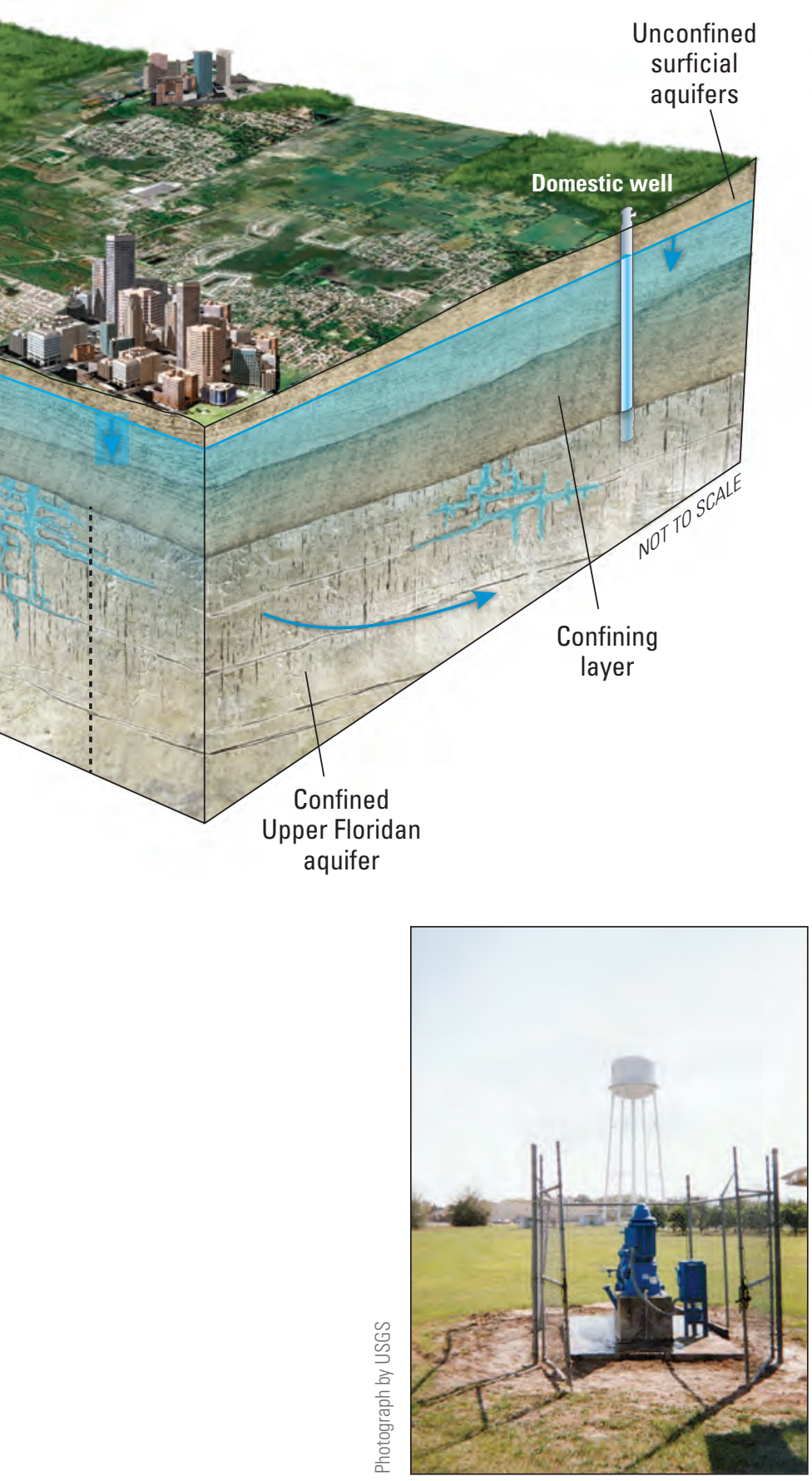
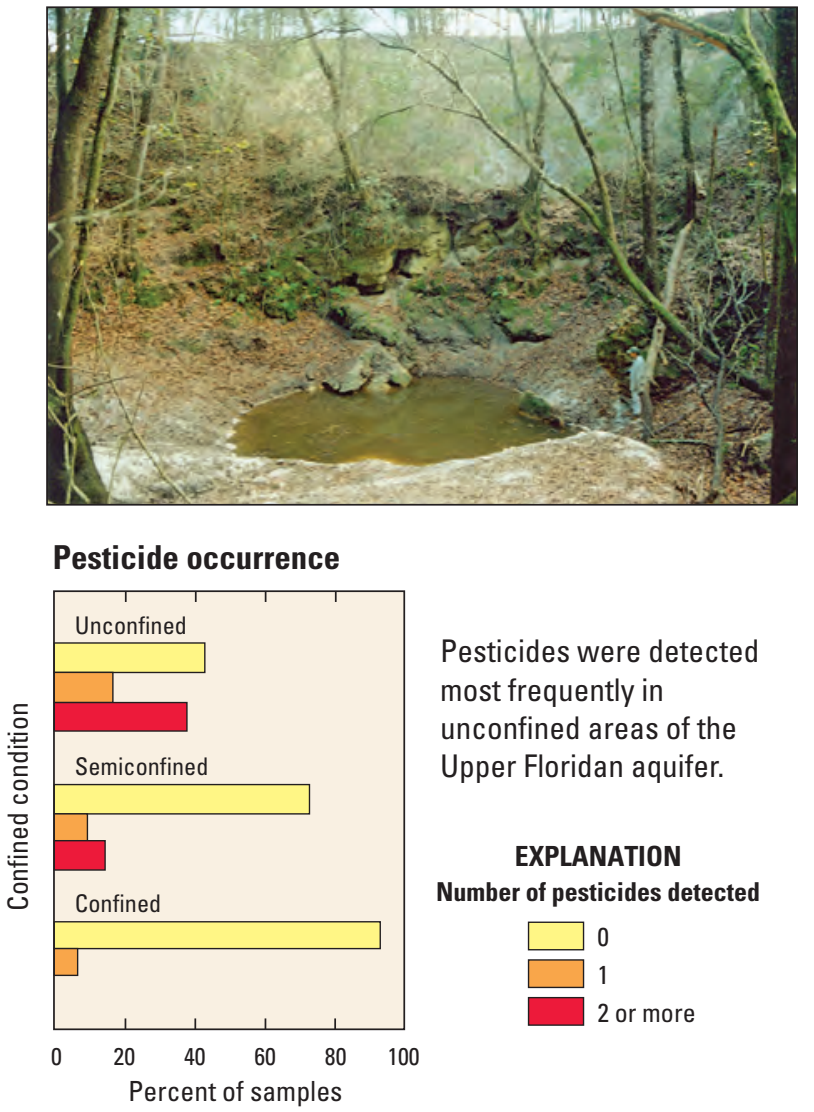

\section{Alteration of groundwater flow can change geochemical conditions and increase groundwater vulnerability to contamination}

The pumping of public-supply wells in the Upper Floridan aquifer can move water that contains dissolved oxygen from the surficial aquifer into the Upper Floridan aquifer. The infusion of oxygen during pumping into areas where the Upper Floridan aquifer does not contain oxygen can cause arsenic to be released into the groundwater. In addition, this shallow water can bring with it elevated concentrations of nitrate or other contaminants from urban and agricultural sources at the land surface. Understanding how the aquifer geochemistry changes as a result of large-volume pumping is vital to the sustainability of this important resource. See page 38-39. 


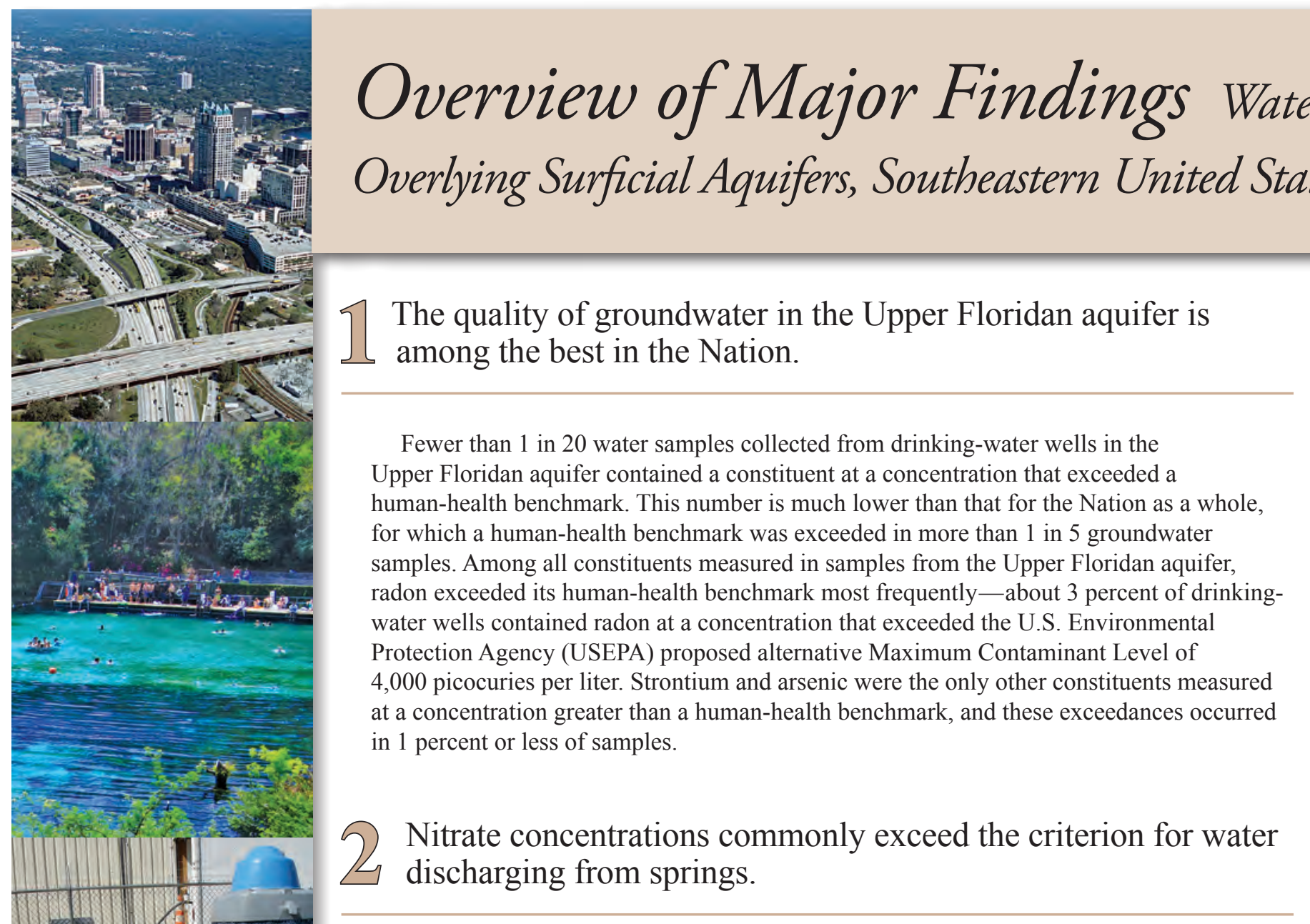

Somewhat surprisingly, nitrate concentrations in the Upper Floridan aquifer in many areas have remained relatively low, despite widespread sources of nitrogen. Of the 252 groundwater samples collected from the Upper Floridan aquifer, only one sample had a nitrate concentration greater than the Maximum Contaminant Level of 10 milligrams per liter $(\mathrm{mg} / \mathrm{L})$ as nitrogen. Nearly half of the samples, however, had nitrate concentrations greater than the recently adopted criterion of $0.35 \mathrm{mg} / \mathrm{L}$ for springs in Florida. Although these concentrations are not a concern for human health, even small increases in nitrate concentrations might have adverse effects on the groundwater quality. Much of the groundwater in the Upper Floridan aquifer discharges as "crystal-clear" spring flow that supports a variety of aquatic plants and animals throughout the State of Florida. In addition, many large springs are recreational destinations that contribute substantially to the economies of the surrounding areas. Over the past several decades small increases in nitrate concentrations have degraded groundwater quality, and many spring runs have suffered from an increase in nuisance aquatic vegetation, reduced clarity, and harmful algal blooms, which can impair the recreational use of springs. 


\section{Quality Issues for the Upper Floridan Aquifer and}

\section{The absence of an upper confining layer and the presence of karst features increase the vulnerability of parts of the Upper Floridan aquifer to contamination from human activities.}

Karst features, such as sinkholes and large conduits, have developed in areas where the Upper Floridan aquifer is unconfined and where rain and soil water can dissolve away the carbonate rock. These karst features play a particularly important role in controlling the vulnerability of groundwater to contamination because they allow contaminants to move rapidly from the land surface into the aquifer. Karst features are common in the Upper Floridan aquifer in southwestern Georgia and north-central Florida. Activities associated with agriculture in these areas are sources of many contaminants, including nitrate and pesticides. In these areas, nitrate concentrations greater than $1 \mathrm{mg} / \mathrm{L}$ as nitrogen were measured in more than half of the samples collected compared to about 10 percent of samples collected in other areas. Similarly, one or more pesticides were detected in more than half of the samples in these areas compared to about 20 percent of samples in other areas, although pesticide concentrations were low (near their detection levels) throughout the study area.

A critical aspect of protecting the Upper Floridan aquifer as a source of drinking water is the consideration of karst features in the transport of contaminants from land surface. Continued public outreach and education can increase awareness of the importance and vulnerability of karst water resources.

\section{Alteration of groundwater flow can change geochemical conditions and increase groundwater vulnerability to contamination.}

Alteration of groundwater flow and geochemistry, either by high-volume pumping or aquifer storage and recovery projects, can have unintended consequences for water quality. In some areas, high-volume pumping from the Upper Floridan aquifer for public water supply has increased the downward movement of water from the surficial aquifers into the Upper Floridan aquifer. This shallow water can bring with it elevated concentrations of nitrate and other contaminants from sources at the land surface. Also, as oxic (contains oxygen) water from surficial aquifers mixes with water in the underlying Upper Floridan aquifer, which typically contains little or no dissolved oxygen, the resulting change in the geochemistry in the Upper Floridan aquifer can cause minerals to dissolve and release contaminants, such as arsenic, into the groundwater. Aquifer storage and recovery projects, which inject oxic surface water into the aquifer during wet periods and withdraw it for use during dry periods, also change the aquifer geochemistry and can mobilize arsenic.

As the demand for water grows in areas overlying the Upper Floridan aquifer, changes in water quality may occur as more water is pumped from the Upper Floridan aquifer and more aquifer storage and recovery projects are undertaken. Understanding how the aquifer geochemistry changes as a result of these withdrawals is vital to the sustainability of this important resource.

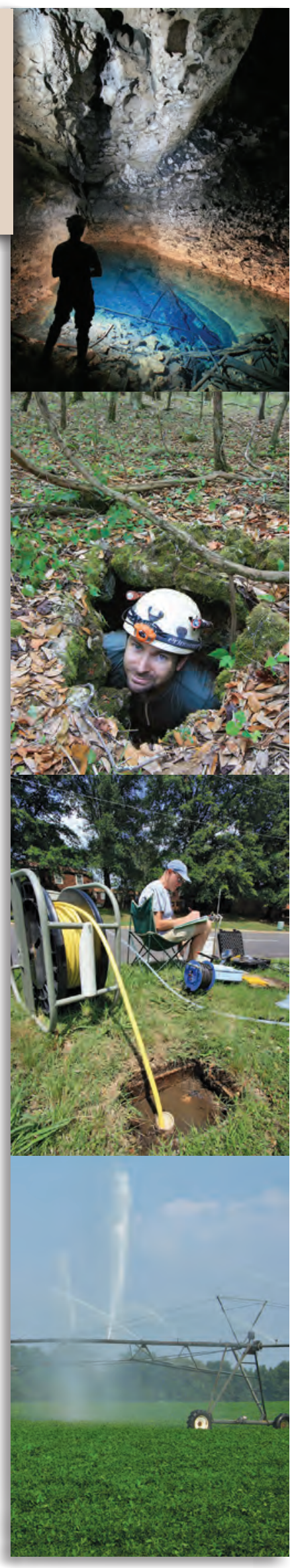




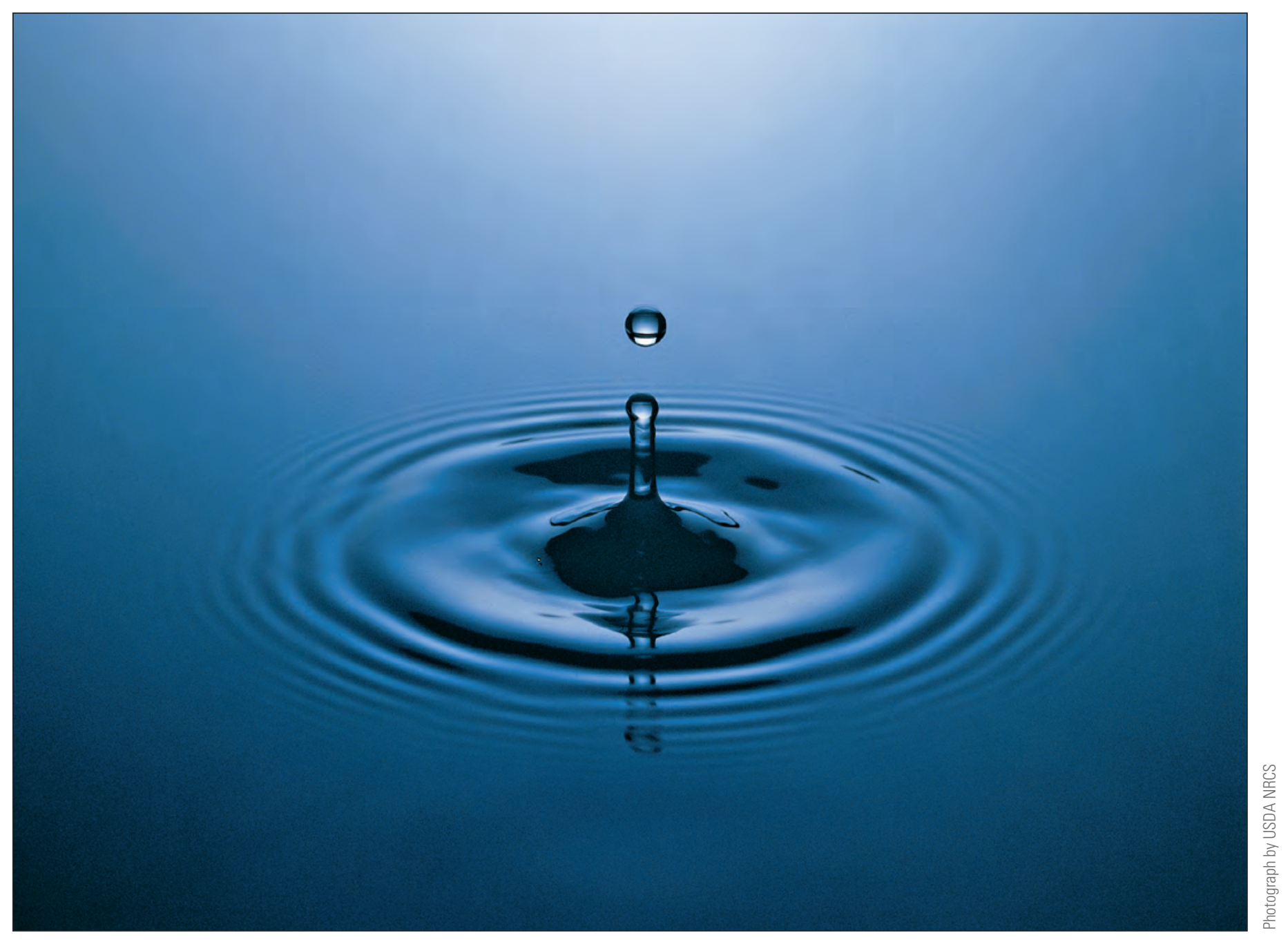




\section{Assessing the Water Quality in the Upper Floridan and Surficial Aquifers}

How does one go about characterizing the groundwater over an area as large as that covered by the Upper Floridan aquifer, let alone the whole United States? The approach taken by the USGS is to use different types of groundwater studies to gain a better understanding of how and why water quality varies. These groundwater studies are the building blocks of the NAWQA water-quality assessments of Principal Aquifers. Many studies were conducted in each Principal Aquifer, each with a different focus on information needs about groundwater quality and the natural and human-related factors that influence the aquifer (table 2-1; appendix 1).

Groundwater studies were designed to answer the following questions: How does land use affect groundwater quality? How does water quality change as it moves through the aquifer? What is the quality of the drinking-water resource? Groundwater studies designed to broadly assess water-quality conditions in aquifers used as a source of drinking water focused on sampling existing water-supply wells (these studies are called major aquifer studies). Agricultural and urban land-use studies designed to characterize and explain the quality of recently recharged groundwater (generally less than 10 years old) ${ }^{(1)}$ in these land-use settings focused on sampling mostly shallow monitoring (nonpumping) wells that were installed as part of the NAWQA Program. Other studies focused on public water supplies or groundwater quality along individual flow paths. ${ }^{(2,3)}$

Almost 400 wells were sampled to characterize the water quality of the Upper Floridan and surficial aquifers.

This Principal Aquifer assessment brings together and interprets results from all of the NAWQA groundwater studies in the Upper Floridan and surficial aquifers. Throughout this assessment, the results are grouped to characterize groundwater used as a drinking-water resource and to characterize the quality of groundwater that has recently recharged in urban and agricultural land-use settings.

Table 2-1. Summary of studies and types of wells sampled in the surficial and Upper Floridan aquifers from 1993 to 2010.

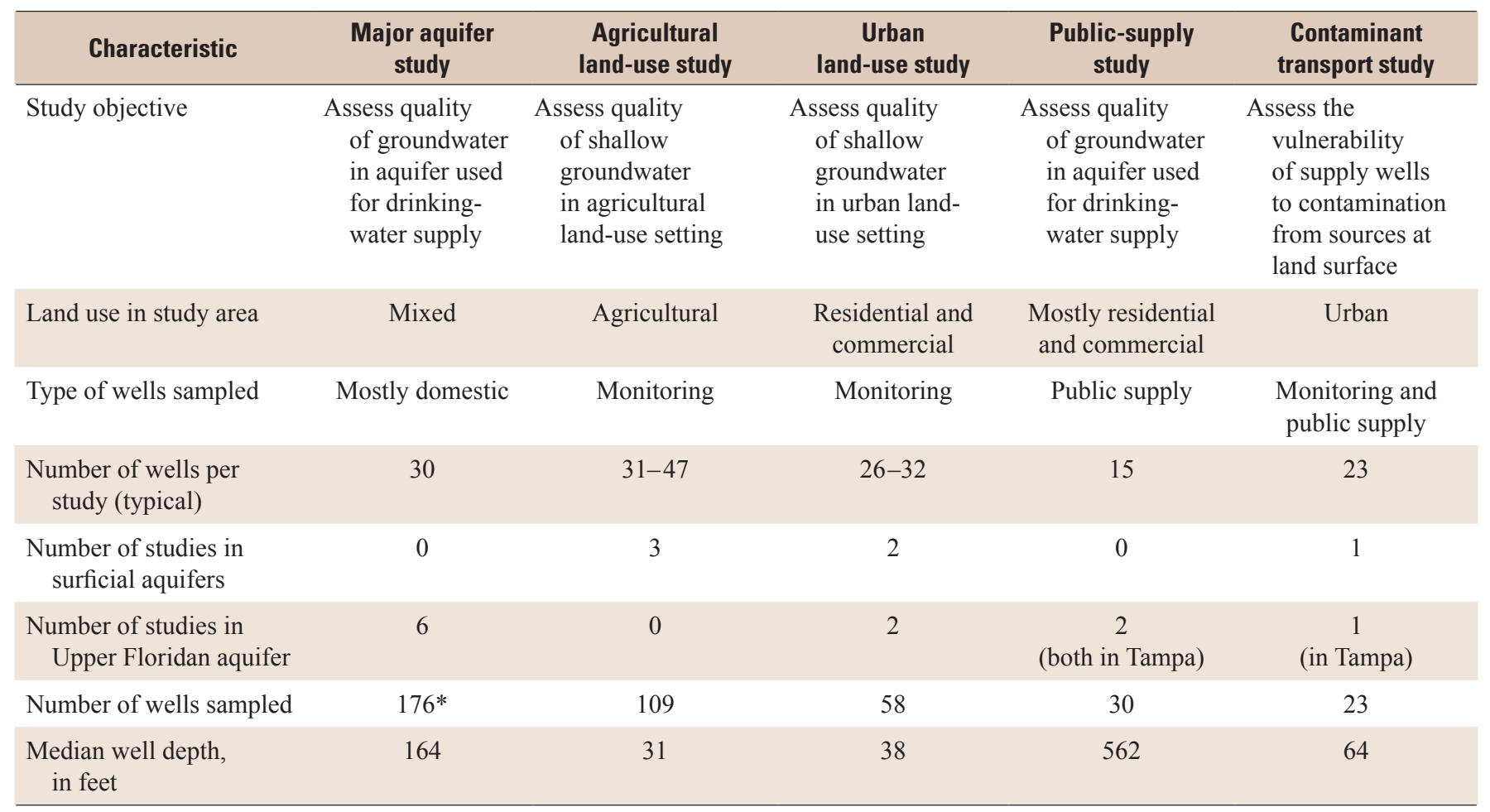

"Includes 22 springs. 
Land-use studies allow us to evaluate how our activities and the chemicals we use affect groundwater quality, and the results can provide an early warning for potential contamination of drinking-water resources. To assess the quality of recently recharged groundwater, 167 wells in urban or agricultural areas were sampled one time each. Most of these wells were shallow monitoring wells installed by the USGS in the surficial aquifers (fig. 2-1) - about 100 of these wells were in agricultural areas (table 2-1). The primary agricultural setting studied was row crops, such as cotton, soybeans, and corn. Row crops in this region require irrigation, and pesticides typically are applied to these crops - two factors that can affect the quality of the underlying groundwater. About 60 of the shallow wells were in urban land-use settings similar to those where many people work and live - single- and multi-family residential and commercial developments, mostly in the suburbs of Ocala and Tampa, Fla. High-volume pumping for public supply and nonpoint-source contamination from urban land-use settings can affect the quality of the underlying groundwater. The wells from which samples were collected for the agricultural and urban land-use studies range from 12 to 250 feet (ft) deep and tap groundwater near the water table. The water quality of shallow groundwater is an indication of how the chemicals we use in day-to-day life - pesticides, solvents, gasoline - might someday affect the quality of the drinking-water resource.

To assess the quality of groundwater used as a drinkingwater resource, one sample was analyzed from each of about 180 randomly selected existing water-supply wells in the Upper Floridan aquifer (see sidebar, NAWQA assessments use a wide range of geochemical data and site information, p. 13, and appendix 1). About 85 percent of the wells sampled were drinking-water wells. These wells were distributed across the study area, and nearly all of them were domestic (private) wells (fig. 2-1). The remaining 15 percent of wells included some irrigation and aquaculture wells and other private wells that were not used as a source of drinking water. The wells sampled ranged in depth from very shallow ( $38 \mathrm{ft}$ ) to quite deep ( $800 \mathrm{ft}$ ), but three-fourths of the wells were less than about $250 \mathrm{ft}$ deep (table 2-1). Public-supply and monitoring wells in the Tampa, Fla., area were sampled to characterize the transport of contaminants to the Upper Floridan aquifer and to assess the quality of water used for public supply.

\section{Wells sampled in surficial aquifers}

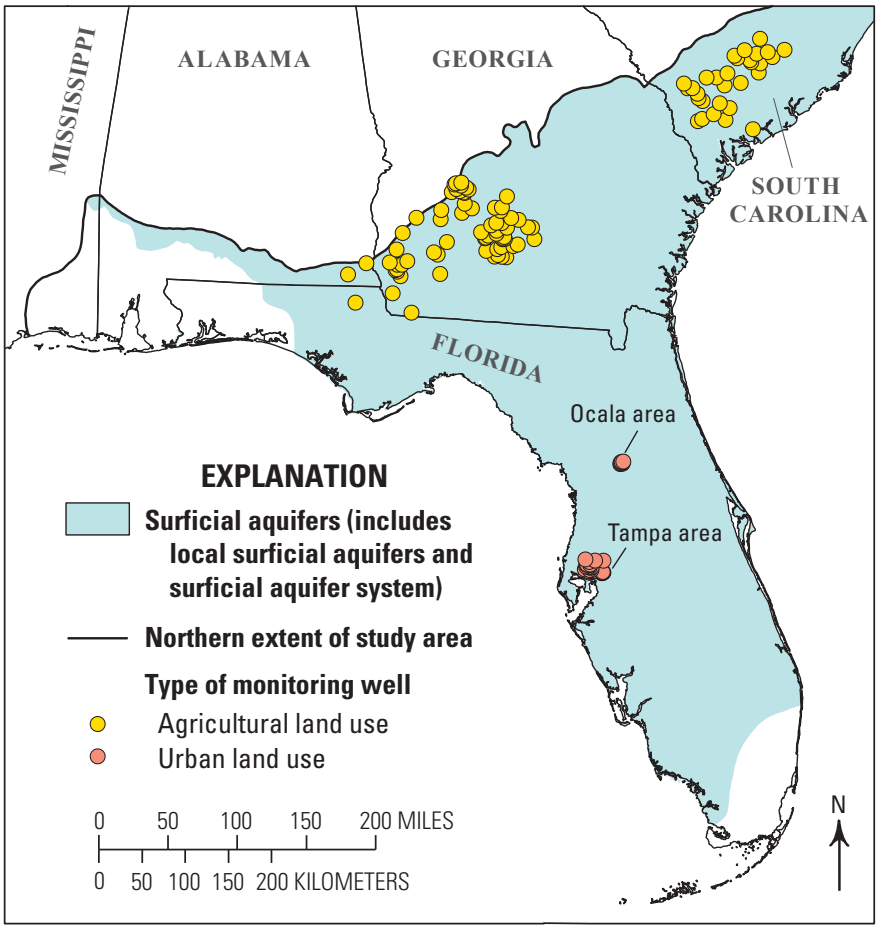

\section{Wells sampled in the Upper Floridan aquifer}

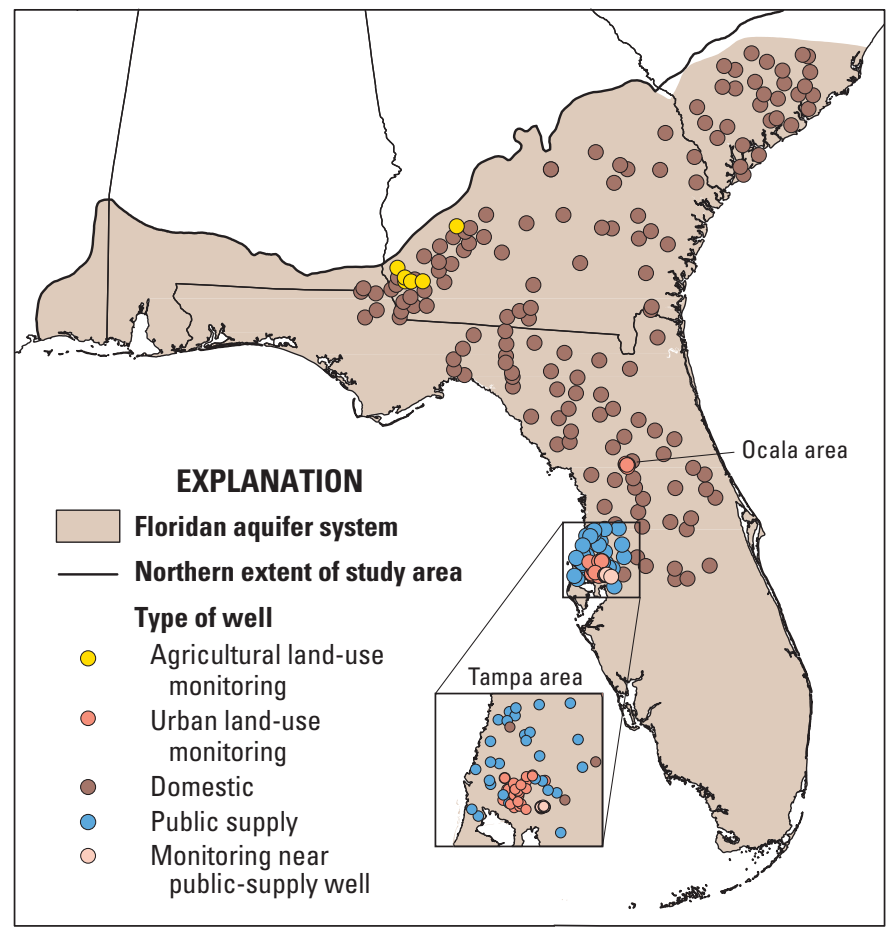

Figure 2-1. About 130 shallow monitoring wells tapping surficial aquifers were sampled from 1993 to 2010 . About 250 wells tapping the Upper Floridan aquifer were sampled during this same time period. Wells tapping the Upper Floridan aquifer were deeper than the surficial wells and included wells used for drinking-water supply_domestic and public-supply wells—in addition to some monitoring wells in urban and agricultural areas. 


\section{Aquifer (aq.ui.fer)—ăk'wə-fər}

An underground layer of saturated permeable materials (rock, gravel, sand, or silt) that will yield a useful quantity of water to a well.

The unsaturated zone is the area below the land surface and above an aquifer. In addition to soil, rocks, and air, the unsaturated zone contains water from the land surface (such as rain) that is slowly moving downward to the water table of the aquifer.

An unconfined aquifer is bounded at its top by the water table, below which water fills all the pore spaces in the rock. Water from the land surface can move down into an unconfined aquifer.

A confining layer is a layer of material (often clay) through which water does not easily flow, creating a boundary between aquifers.

A confined aquifer is bounded at its top by a confining layer. Water enters or "recharges" confined aquifers where the confining layer is not present. Where the confining layer is not continuous or is breached (for example, by a well), flow between the unconfined and confined aquifer can occur.

The pressure within a confined aquifer can be greater than that in the overlying unconfined aquifer if the source of the water in the confined aquifer is at a higher elevation than the unconfined aquifer. In that case, water in a well in a confined aquifer will rise to a higher level than that in the overlying unconfined aquifer.

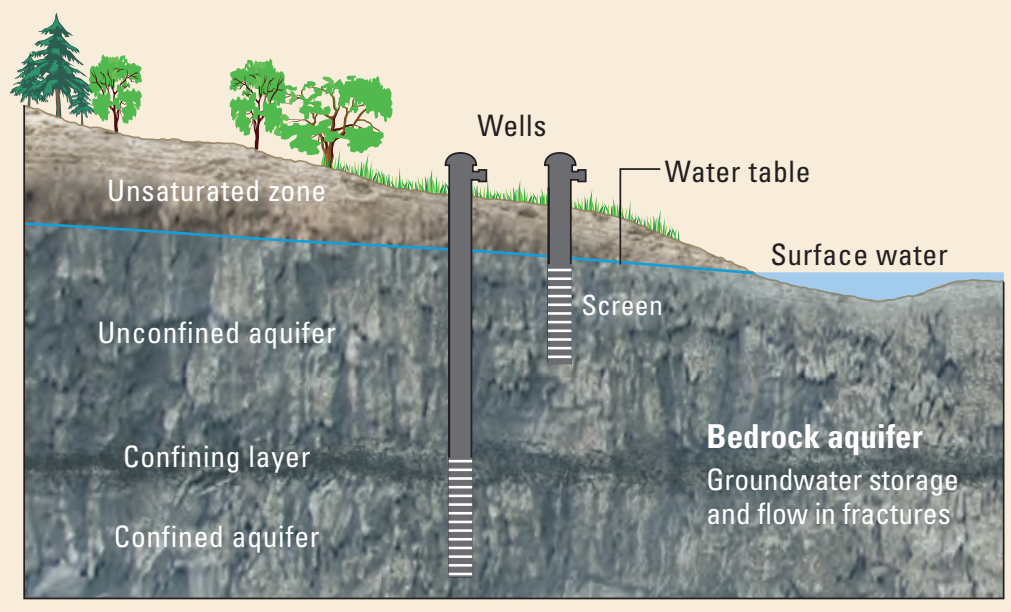

Carbonate aquifer Groundwater storage and flow in solution cavities or fractures

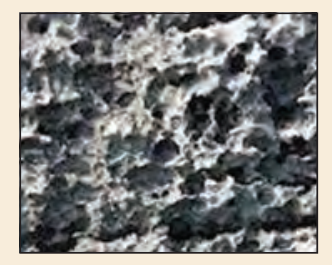

\section{Anatomy of a well}

A well is simply a hole in the ground (well bore or borehole) from which water can be removed. The well bore is lined with a well casing, such as a pipe, to prevent the well bore from collapsing. The casing, along with a sealant (called grout), also prevents water from flowing into the well from the land surface or from parts of the aquifer where the water quality may be less desirable. The casing can be open at the bottom or perforated at a specific depth with a screen, to allow water to flow into the well where it can be pumped to the surface. Coarse sand or gravel (called sand pack or gravel pack) can be placed around the well screen to help improve the flow of water into the well. Some wells are cased only near the land surface, allowing water to flow into the well from nearly the entire length of the well bore.

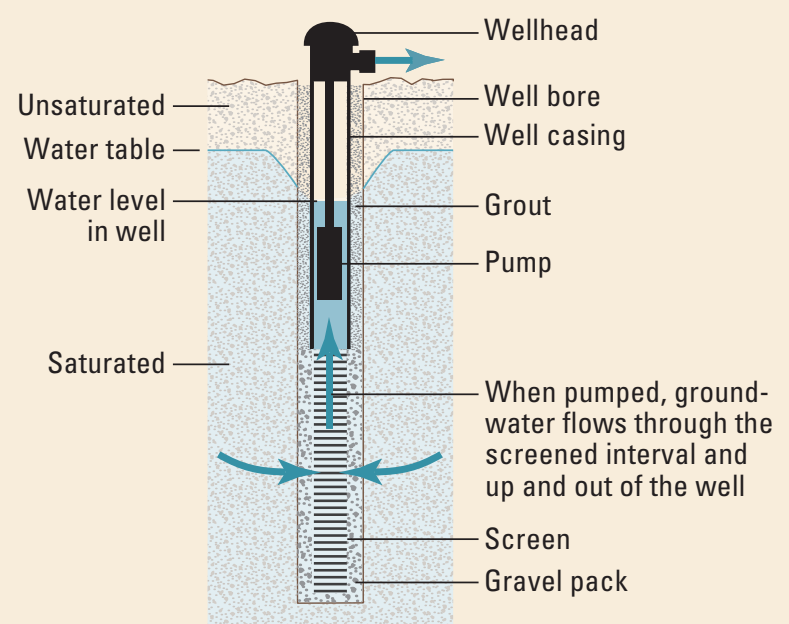




\section{Understanding study results}

\section{Important aspects of the NAWOA Principal Aquifer assessments:}

- Water samples were collected at the wellhead (see sidebar, Anatomy of a well, p. 10) prior to any treatment. They represent the quality of the groundwater resource but not necessarily the quality of tap water.

- The focus of the assessments is the condition of the total resource, including groundwater in a wide range of hydrologic and land-use settings across the Nation, rather than conditions at specific sites with known water-quality concerns.

- The assessments are guided by a nationally consistent study design, and all assessments use the same methods of sampling and analysis. Findings apply to water quality of a particular aquifer but also contribute to the larger picture of how and why water quality varies regionally and nationally. This consistent approach helps to determine if a water-quality issue is isolated or widespread. (See http://water.usgs. gov/nawqa/about.htm/for more information.)

- The assessments focus on aquifers used for water supply or on shallow groundwater that underlies an area with a particular type of land use. Because the NAWOA groundwater study areas do not cover the full spatial extent of the targeted Principal Aquifer, the findings might not represent the effects of the full range of geology, climate, and land use present.

- Analytical methods used by USGS chemists for assessments of water quality in Principal Aquifers are designed to measure constituents at as low a concentration as possible. As a result, constituents frequently are detected at concentrations far below human-health benchmarks for drinking water (see sidebar, Human-health benchmarks and other guidelines used in this assessment, p. 32). Low-level detections allow scientists to identify and evaluate emerging issues and to track contaminant levels over time.

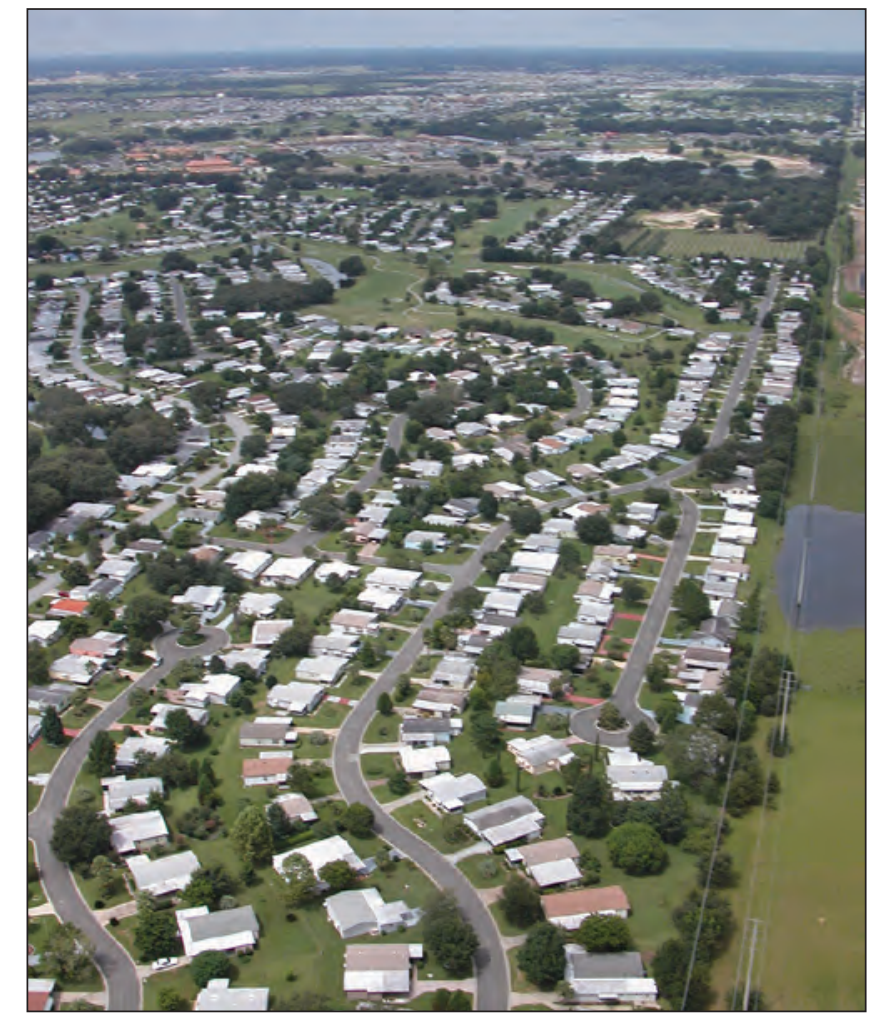

Samples of shallow groundwater were collected from the surficial and Upper Floridan aquifers underlying the cities of 0 cala and Tampa, Florida. The quality of water indicates how chemicals that we use in our daily lives affect groundwater. 


\section{The types of wells sampled and how well type can affect the quality of the water collected}

Many of the groundwater samples analyzed for this water-quality assessment were collected from shallow monitoring wells. Monitoring wells are not pumped regularly - they are used for measuring water levels or occasionally collecting water samples, but they are not used for drinking water, irrigation, or other purposes. Monitoring wells sampled in the NAWOA groundwater studies were installed expressly for the purpose of monitoring groundwater quality. Because monitoring wells typically tap shallow groundwater that has recently recharged the aquifer and that is close to the land surface where chemicals are applied, the water pumped is more likely to contain manmade contaminants than water pumped from deeper wells.

Groundwater samples also were collected from two types of wells that supply drinking water: domestic (private) wells and public-supply wells. Both well construction and land-use setting can affect the water quality of the samples collected. Domestic wells typically are shallower than public-supply wells, so they pump water that is nearer to sources of manmade contaminants, such as fertilizers and pesticides, at the land surface. Domestic wells commonly are in rural areas and thus are more likely than public-supply wells to be vulnerable to contamination from agricultural chemicals. Public-supply wells pump water from deeper in the aquifer and commonly are in suburban and urban areas, so they are more likely than domestic wells to be vulnerable to contamination from chemicals associated with urban activities. Public-supply wells have larger pumps and longer screened intervals than do domestic wells and are pumped for longer periods of time. As a result, public-supply wells pump much larger volumes of water than do domestic wells and so have much larger capture zones; therefore, public-supply wells are more vulnerable than are domestic wells to manmade contamination from distant sources. If the amount of water pumped is large enough, it can change the direction and speed of groundwater flow, which can, in turn, affect the geochemistry of the groundwater. Routine testing of water from domestic wells is not required, and so homeowners are responsible for testing, maintenance, or treatment of the water from their domestic wells. Water from public-supply wells is required to be tested by the well operator on a routine basis to help assure that the water provided to consumers meets Federal and State water-quality standards.

Finally, some groundwater samples were collected from wells that supply water for purposes other than drinking, such as irrigation and aquaculture. These wells can have pumping rates similar to or greater than those of public-supply wells; they might be pumped every day or only during spring and summer. Depending on their depth, location, and pumping rate, these supply wells might be more or less vulnerable than drinking-water wells to contamination associated with agriculture or urban activities.
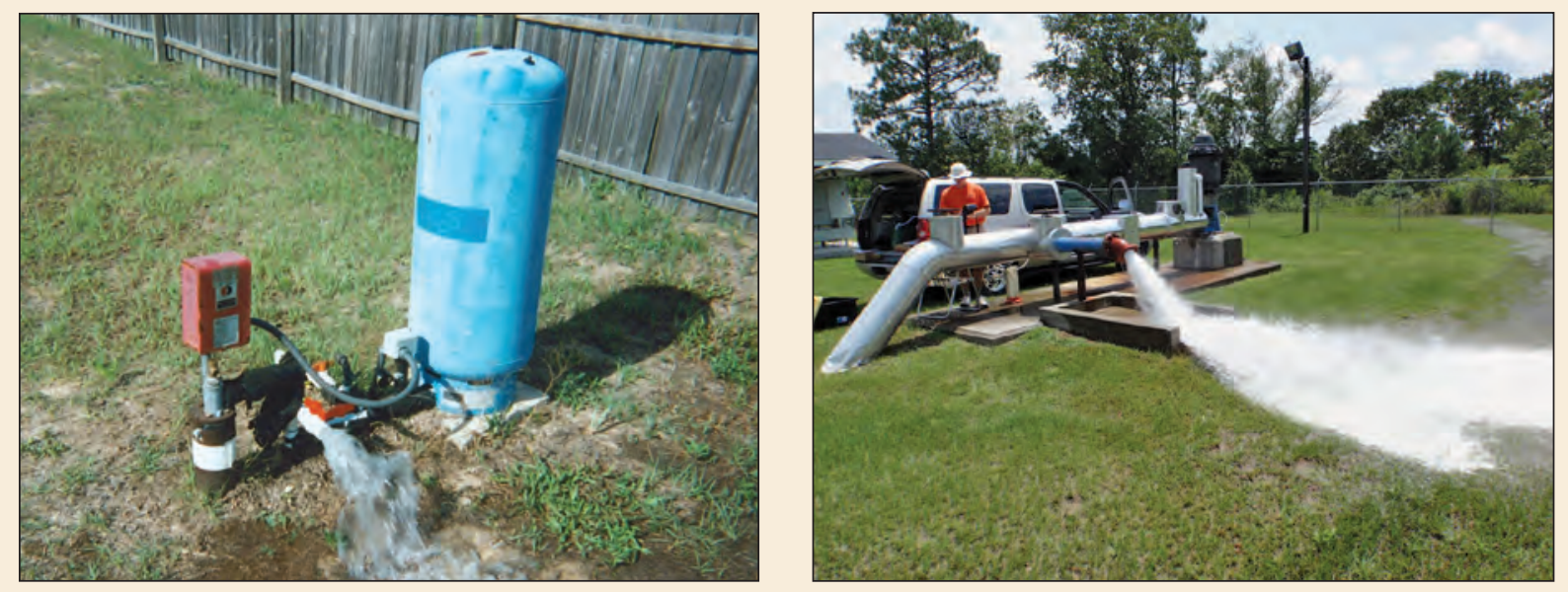

(Left) Domestic and (right) public-supply wells were the primary type of water-supply wells sampled. 


\section{NAWQA assessments use a wide range of geochemical data and site information}

\begin{tabular}{|c|c|}
\hline \multicolumn{2}{|c|}{ Constituents measured in samples from most wells } \\
\hline Constituent group & Examples \\
\hline Water-quality properties & $\begin{array}{l}\mathrm{pH} \text {, specific conductance, dissolved } \\
\text { oxygen, temperature }\end{array}$ \\
\hline Major ions (filtered) & $\begin{array}{l}\text { Bromide, calcium, chloride, } \\
\text { magnesium, sodium, sulfate }\end{array}$ \\
\hline Trace elements (filtered) & $\begin{array}{l}\text { Arsenic, boron, iron, manganese, } \\
\text { selenium, uranium }\end{array}$ \\
\hline Nutrients (filtered) & Ammonia, nitrate, phosphorus \\
\hline Pesticides (filtered) & Herbicides, insecticides, fungicides \\
\hline $\begin{array}{l}\text { Volatile organic } \\
\text { compounds }\end{array}$ & $\begin{array}{l}\text { Solvents, gasoline hydrocarbons, } \\
\text { refrigerants, trihalomethanes, } \\
\text { fumigants }\end{array}$ \\
\hline Organic carbon (filtered) & \\
\hline \multicolumn{2}{|c|}{ Additional constituents measured in samples from some wells } \\
\hline Constituent group & Examples \\
\hline Radionuclides & Radon \\
\hline Groundwater age tracers & Tritium, chlorofluorocarbons \\
\hline Stable isotopes & Oxygen-18, hydrogen-2 \\
\hline Microorganisms & Escherichia coli and total coliforms \\
\hline \multicolumn{2}{|c|}{ Additional site information } \\
\hline $\begin{array}{l}\text { Use of well } \\
\text { Well depth } \\
\text { Depth to water } \\
\text { Well-construction data } \\
\text { Principal Aquifer }\end{array}$ & $\begin{array}{l}\text { Land-surface elevation at well } \\
\text { Land use within a 500-meter } \\
(1,640 \text {-foot) radius buffer } \\
\text { Estimates of nutrient inputs } \\
\text { Estimates of pesticide use }\end{array}$ \\
\hline
\end{tabular}
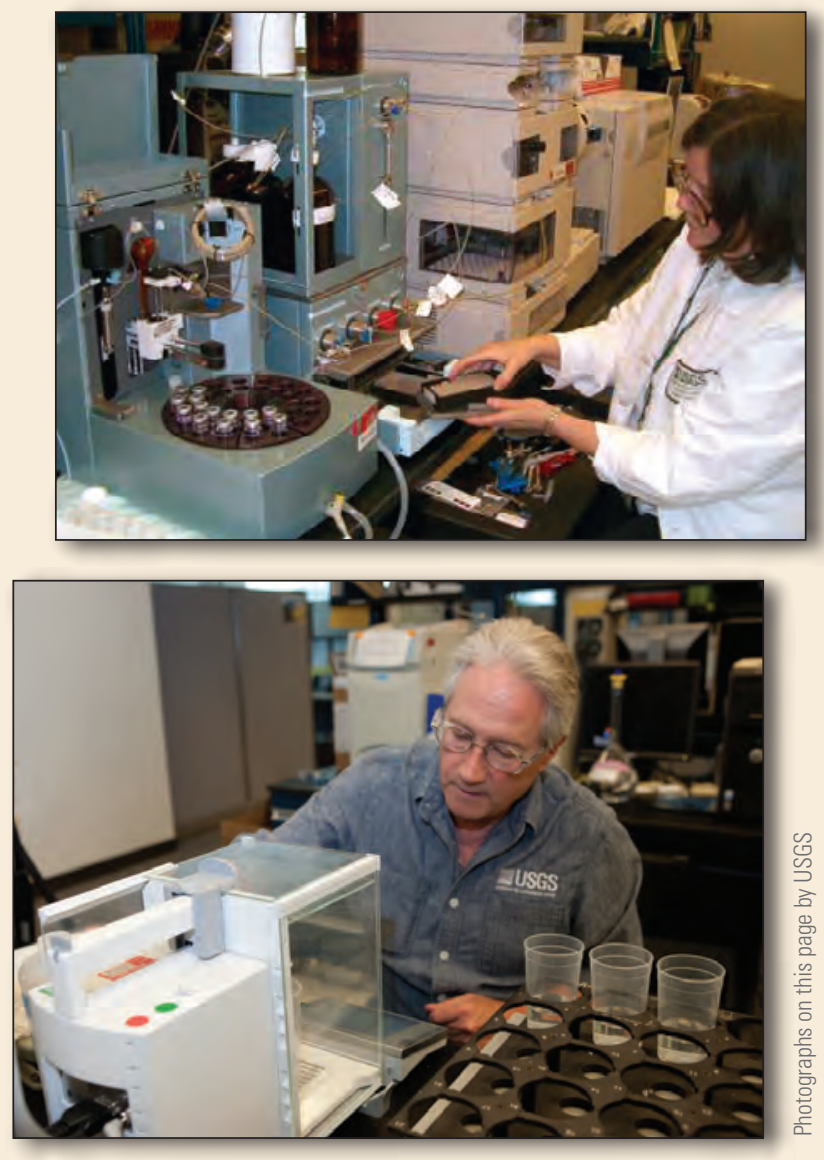

Chemists at the USGS National Water Quality Laboratory analyze groundwater samples using an array of sophisticated techniques.

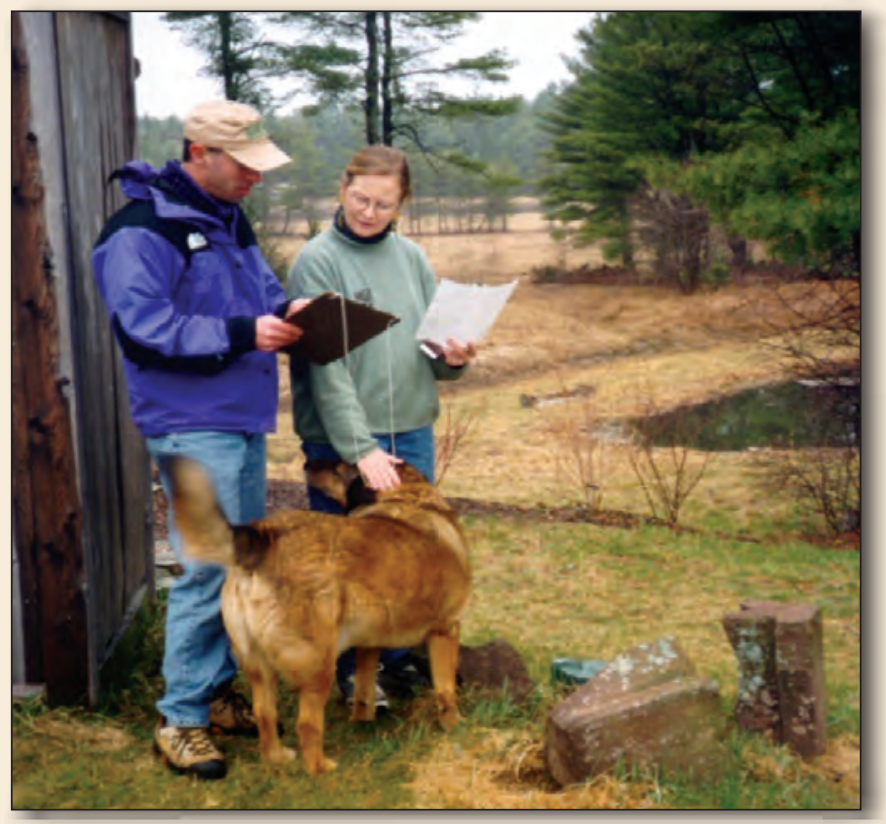

Additional information (often called "ancillary information") about the well and surrounding environment complements the chemical data measured. This additional information often is key to making sense of the chemical data. For example, the information might be used to determine that shallow groundwater is more (or less) vulnerable to contamination than deep groundwater, that domestic wells are more (or less) vulnerable to contamination than publicsupply wells, or that urban land use is associated with different types of groundwater contamination than is agricultural land use. Chemical data without accompanying ancillary data are much less useful for understanding factors that affect groundwater quality. 


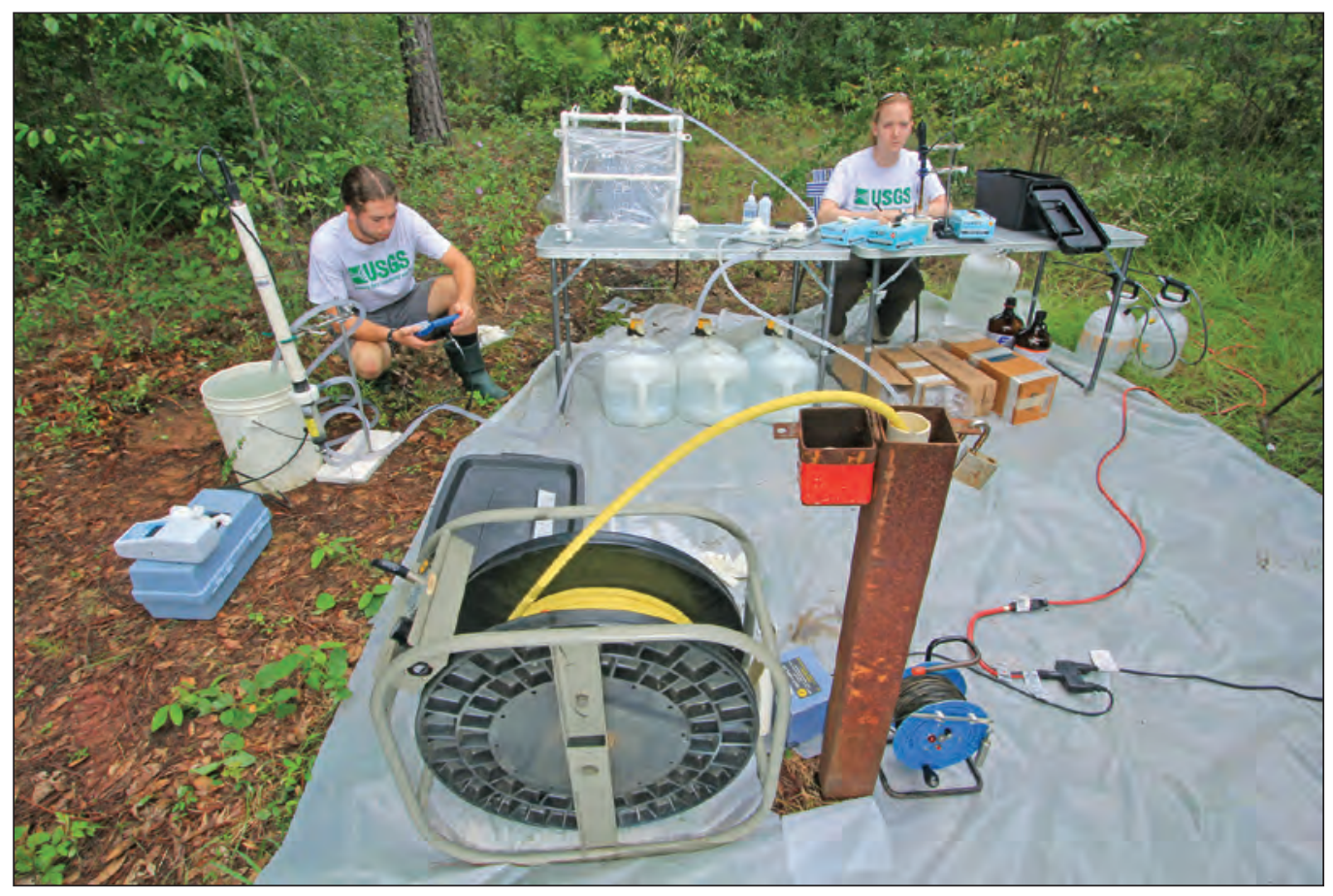

Monitoring wells installed in agricultural and urban areas were sampled to characterize shallow groundwater quality underlying these land uses.

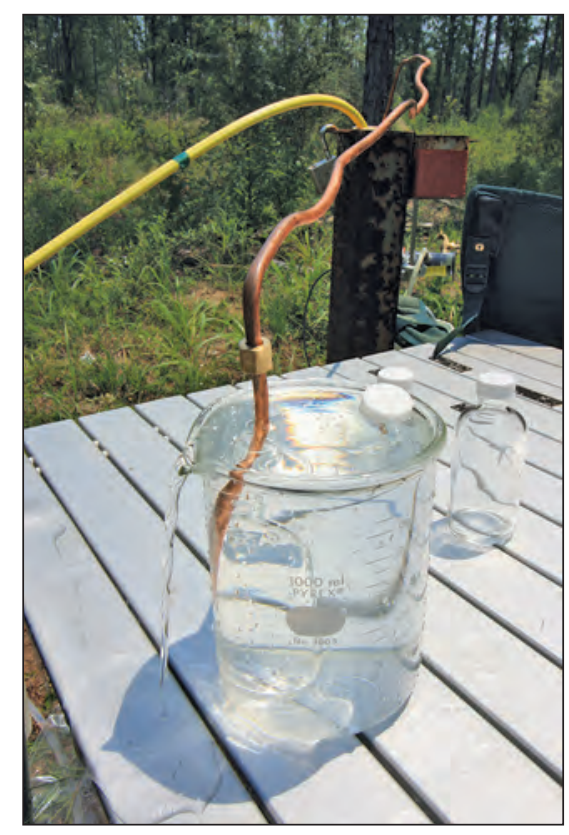




\section{Chapter 3: Environmental and Hydrogeologic Setting}

7 he clear inland springs that issue from the thick carbonate rocks of the Floridan aquifer system appeal to residents and tourists alike, and the temperate to tropical climate, abundant rainfall, and plentiful groundwater make the area a top producer of oranges, tomatoes, and other crops. All of these factors - geology, population growth, climate, and agriculture - affect flow and the quality of groundwater in the Upper Floridan aquifer and overlying surficial aquifers.

Orlando, Florida, is one of several large cities that overlies the Floridan aquifer system and relies on the aquifer for drinking water. The Floridan aquifer system is the source of drinking-water supply to approximately 10 million people, most of them in Florida, Georgia, and South Carolina. Over 4 billion gallons are withdrawn from this aquifer system each day for irrigation, drinking water, and industrial uses.
This chapter summarizes background information for the Upper Floridan aquifer and overlying surficial aquifers and provides the context for understanding findings about water quality in these Principal Aquifers.

The chapter covers the environmental and hydrogeologic setting, including population, land use, and water use.

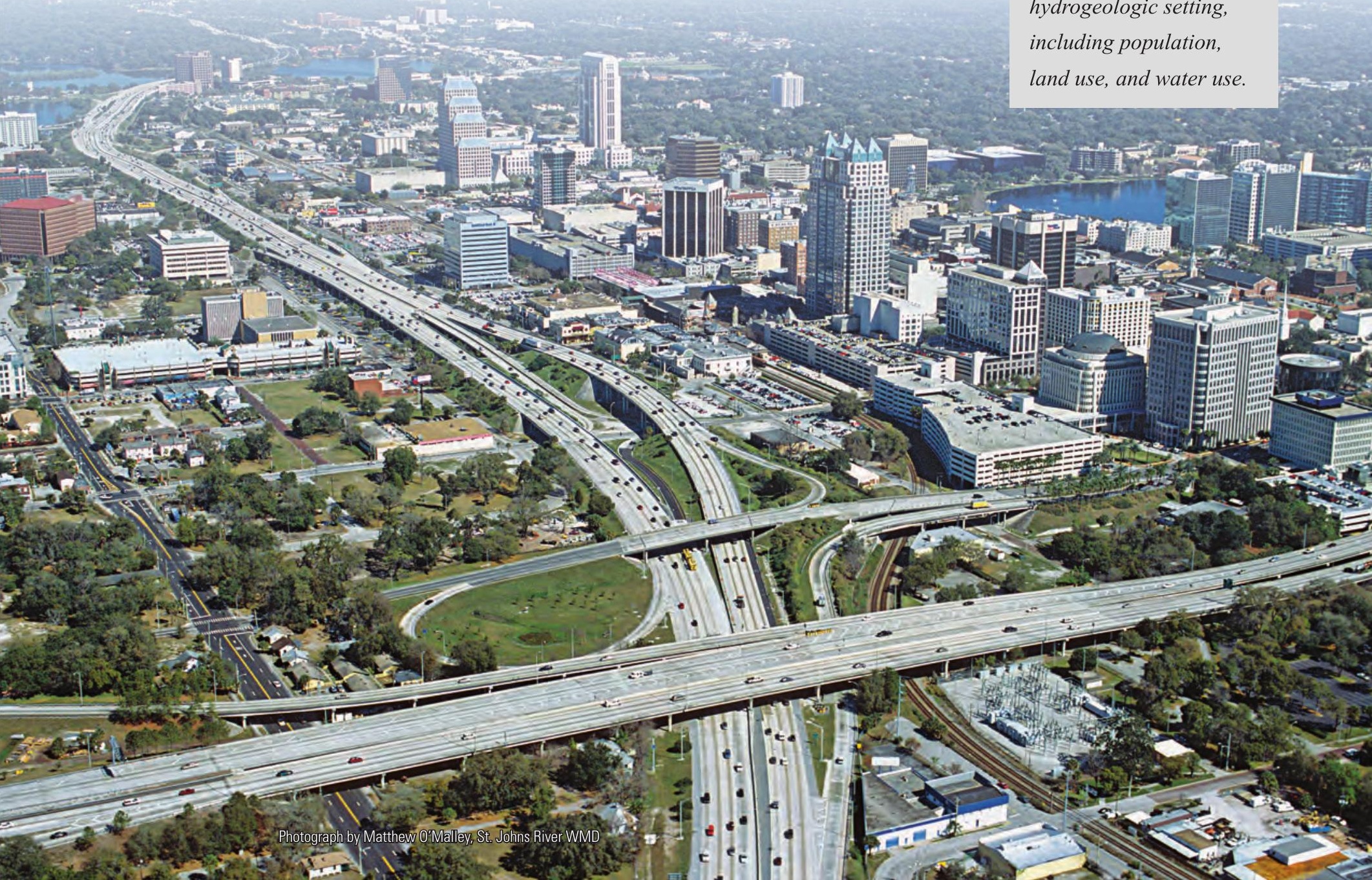




\section{Environmental Setting and Climate}

The Floridan aquifer system underlies a vast areaabout 100,000 square miles $\left(\mathrm{mi}^{2}\right)$ - that includes all of Florida and parts of Alabama, Georgia, Mississippi, and South Carolina (fig. 3-1). Low, gently rolling terrain in the northwestern areas transitions to flat topography near the coasts - the highest point in Florida is a mere $345 \mathrm{ft}$ in elevation. The climate is temperate in the north but subtropical in most of Florida and tropical in south Florida. The area receives substantial rainfall - the long-term average ranges from about 45 inches per year (in/yr) in southeastern Georgia to about $68 \mathrm{in} / \mathrm{yr}$ in southern Alabama, ${ }^{(4)}$ and in some areas rainfall is more than $100 \mathrm{in} / \mathrm{yr}$. The driest areas are in southeast Georgia, and the wettest are in southeast Florida, the western panhandle of Florida, and south Alabama. The wettest times of the year are late winter or early spring and the summer - there is a 50 percent chance of rain on any summer day. Torrential rain is a common occurrence, particularly along the coasts - tropical disturbances or hurricanes can bring rainfall in excess of 3 inches and, in extreme cases, 24-hour amounts of 10 inches or more. The timing and amount of rainfall are key factors that control the amount of water that recharges the aquifers and the rate at which groundwater moves through the aquifers.

\section{The Upper Floridan aquifer is one of the most productive aquifers in the world with 33 springs in Florida alone that each discharge more than 64 million gallons per day.}

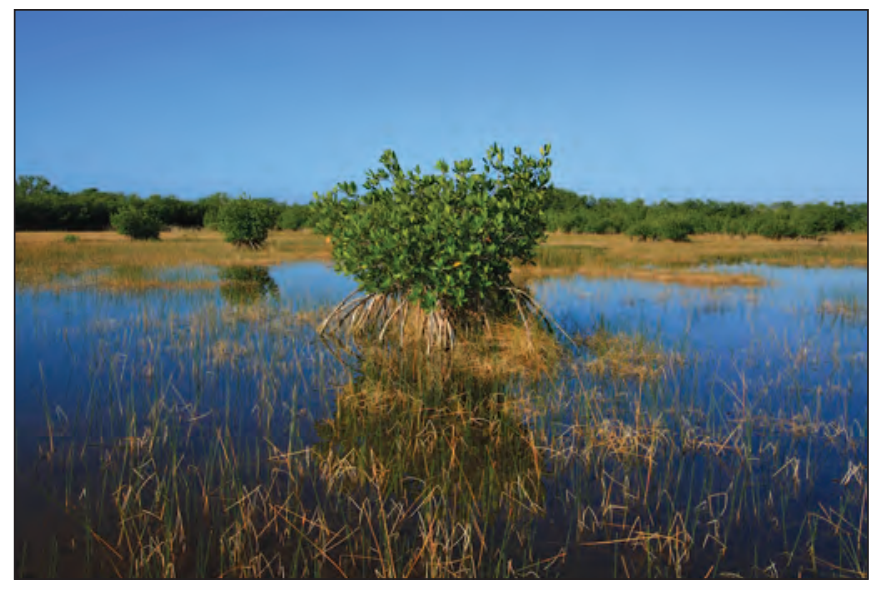

\section{Aquifers overlying the Floridan aquifer system}

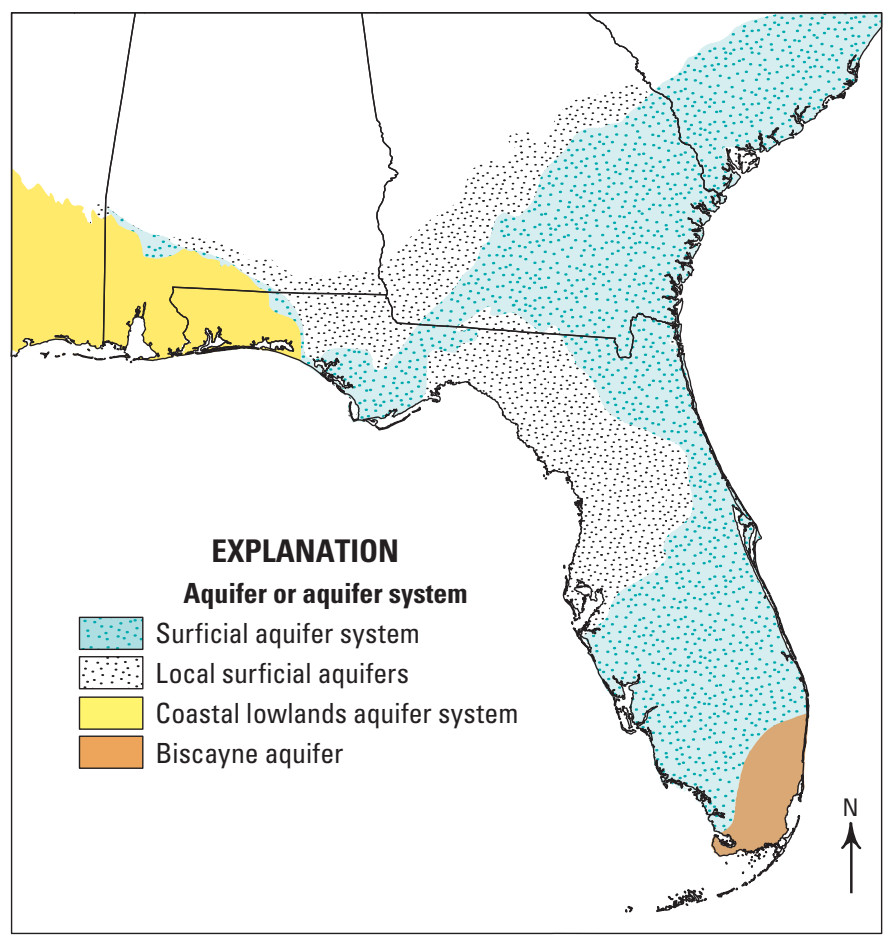

Figure 3-1. Four surficial aquifers or aquifer systems overlie the Floridan aquifer system. Water-quality data for the surficial aquifer system and local surficial aquifers-referred to in this report as "surficial aquifers" - are included in this assessment.

The land overlying the Upper Floridan aquifer is flat and most of it is managed forest, agricultural, or wetlands, as shown here at the Ten Thousand Islands National Wildlife Refuge, Collier County, Florida, (left) and a peanut field in Miller County, Georgia (right). 


\section{Hydrogeologic Setting}

The Floridan aquifer system, one of the most productive aquifers in the world, is composed of a thick sequence of carbonate rocks (limestone and dolomite), which lends the aquifer system many of its unique hydrogeologic characteristics. The limestone and dolomite that make up the Floridan aquifer system can dissolve when they come into contact with acidic rainwater or soil water - the landforms and associated hydrology that form when these rocks dissolve is called "karst" (see sidebar, Karst, p. 20). Karst features that form in the aquifer can allow large amounts of water to move to springs or wells. For example, in Florida alone, there are 33 springs each with flow greater than about 64 million gallons per day (Mgal/d) ${ }^{(5)}$ The Floridan aquifer system is overlain across most of its extent by the surficial aquifer system or by local surficial aquifers (fig. 3-1). In many areas, the Floridan aquifer system is separated from an overlying surficial aquifer by a confining layer, but in some areas the two aquifer systems are in contact (figs. 3-2, 3-3). ${ }^{(6)}$ The Southeastern Coastal Plain aquifer system underlies the Floridan aquifer system, and these aquifers are connected in southern Georgia. ${ }^{(6)}$

The Floridan aquifer system consists of as much as $1,500 \mathrm{ft}$ of carbonate rock-limestone and dolomite. ${ }^{(7)}$ The system is divided into two aquifers - the Upper Floridan aquifer and the Lower Floridan aquifer. The Upper Floridan aquifer is highly permeable and is the primary source of drinking water throughout its extent-in most areas the Upper Floridan aquifer yields water supplies sufficient for most purposes, and there is no need to drill into the Lower Floridan aquifer, which is deeply buried and contains poor-quality water in many areas. This report focuses only on the Upper Floridan aquifer.

The surficial aquifer system and local surficial aquifers consist mostly of beds of unconsolidated sand, shelly sand, and shell and, in some areas, limestone. ${ }^{(6)}$ These aquifers range in thickness from just tens of feet in parts of westcentral and north-central Florida to more than $300 \mathrm{ft}$ along the southeastern Georgia coast and eastern Florida coast. In this report, the term "surficial aquifers" is used to refer to the surficial aquifer system and the local surficial aquifers together (fig. 3-1). The surficial aquifers are unconfined. Most of the water that infiltrates the surficial aquifers moves quickly along short flow paths to discharge as base flow to streams, but some water moves downward into the Floridan aquifer system. ${ }^{(6)}$ The presence of contaminants in surficial aquifers is of concern to local water users, but also to those who use the Upper Floridan aquifer for drinking water.

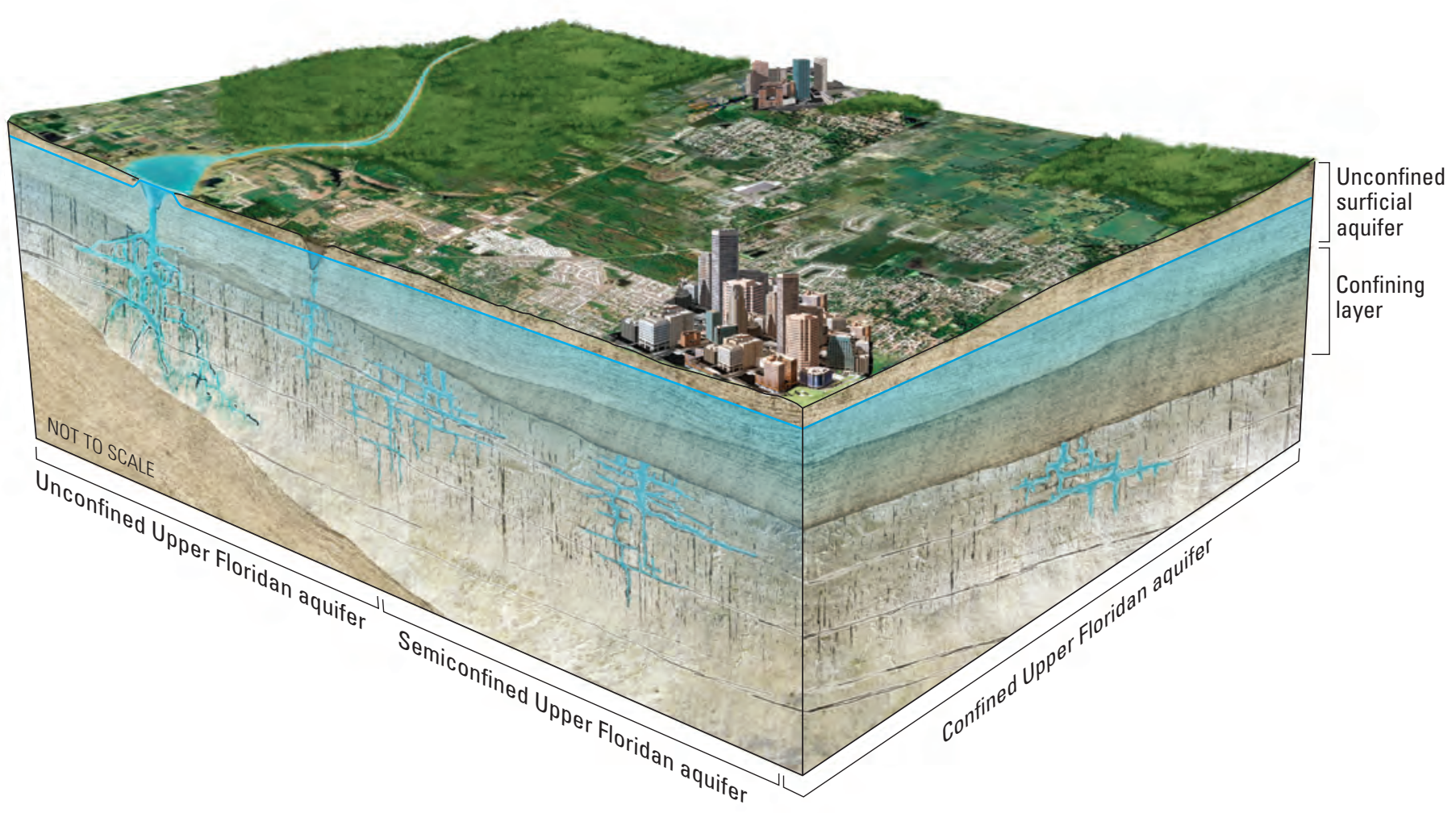

Figure 3-2. Unconfined surficial aquifers overlie the Upper Floridan aquifer. A confining layer of sand, clay, marl, limestone, and dolomite separates these aquifers in many areas. The presence or absence of this confining layer is a key factor that controls the vulnerability of the Upper Floridan aquifer to contamination. 


\section{Confined conditions in the Upper Floridan aquifer}

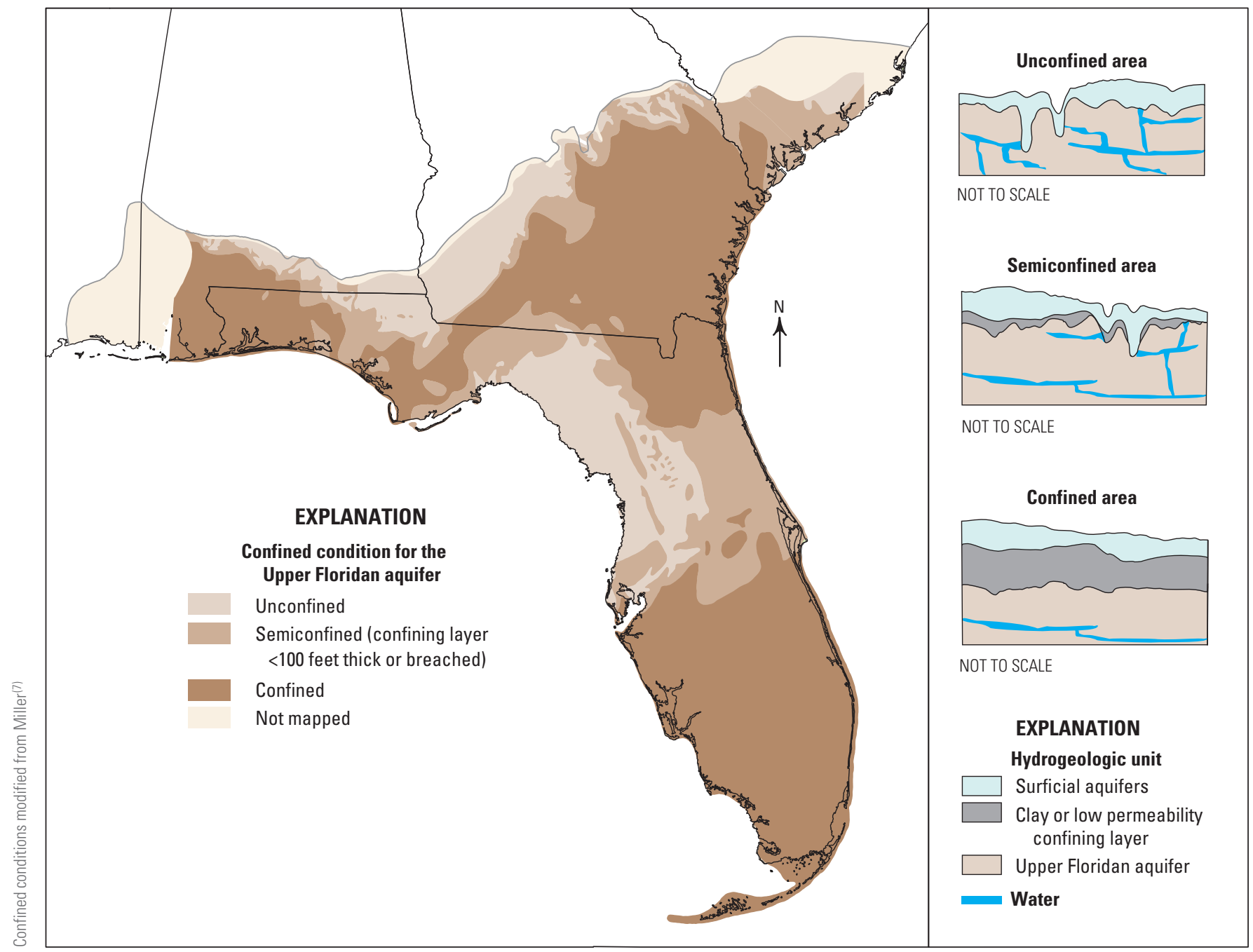

Figure 3-3. The major hydrogeologic feature that affects groundwater flow and quality in the Upper Floridan aquifer is the thickness of the overlying confining layer. Where present, this layer controls the amount of recharge and contaminants that can enter the aquifer.

In most areas, a confining layer composed of sand, clay, marl, limestone, and dolomite of low permeability separates the surficial aquifers from the underlying Floridan aquifer system (figs. 3-2, 3-3). This confining layer ranges in thickness from several feet in parts of southwestern Georgia and west-central and north-central Florida to more than $100 \mathrm{ft}$ in southeastern Georgia, northeastern Florida, and southern Florida. The thickness of the confining layer controls where and how much recharge to the underlying Upper Floridan aquifer occurs. ${ }^{(4)}$ The Upper Floridan aquifer is characterized as being unconfined where the confining layer is absent, semiconfined where the confining layer is less than $100 \mathrm{ft}$ thick or breached, and confined where the confining layer is $100 \mathrm{ft}$ or more thick or continuous ${ }^{(7)}$ (fig. 3-3).

Most of the recharge to the Upper Floridan aquifer is concentrated in areas where the aquifer is unconfined or semiconfined. In some areas, sinkholes in streambeds create a direct hydraulic connection between the stream and the aquifer, capturing much or all of the streamflow and diverting it down into the aquifer. The areas of highest recharge (10 to $25 \mathrm{in} / \mathrm{yr}$ ) are in west-central, northern, and western Florida, and in southwestern Georgia. ${ }^{(4,8)}$ The least amount of recharge (1 in/yr or less) occurs in northeastern Florida and southeastern Georgia (fig. 3-4), where the confining layer is more than $100 \mathrm{ft}$ thick.

Karst features form in unconfined areas of the Upper Floridan aquifer, where the aquifer rocks are exposed or are covered by only a thin layer of sand or soil. Karst also forms in some semiconfined areas, where sinkholes breach the confining layer and allow precipitation to move downward into the aquifer. As a result, karstic parts of the Upper Floridan aquifer are found most commonly in west-central and northcentral Florida, west Florida, and southwest Georgia. 
Estimated predevelopment recharge and discharge

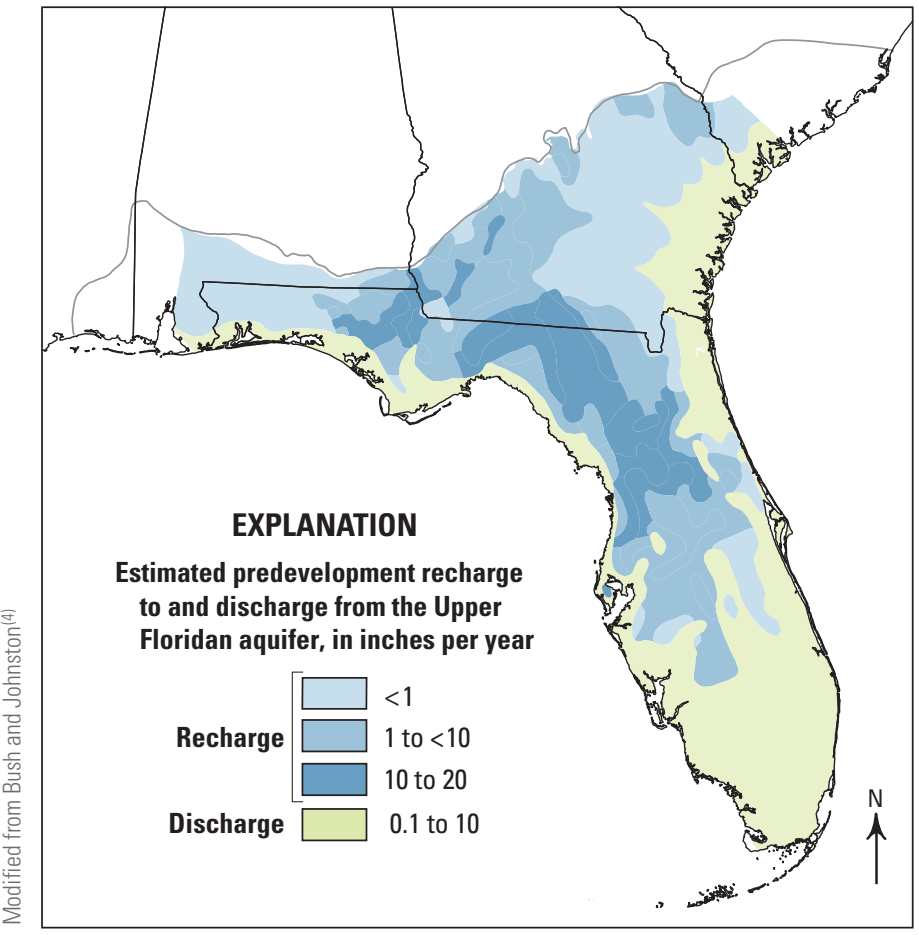

Figure 3-4. The Upper Floridan aquifer receives recharge primarily where the confining layer is less than 100 feet thick. The recharge averages more than 4 inches per year, with some areas receiving more than 10 inches per year. These large amounts of recharge water replenish the aquifer and provide some dilution of contaminants.

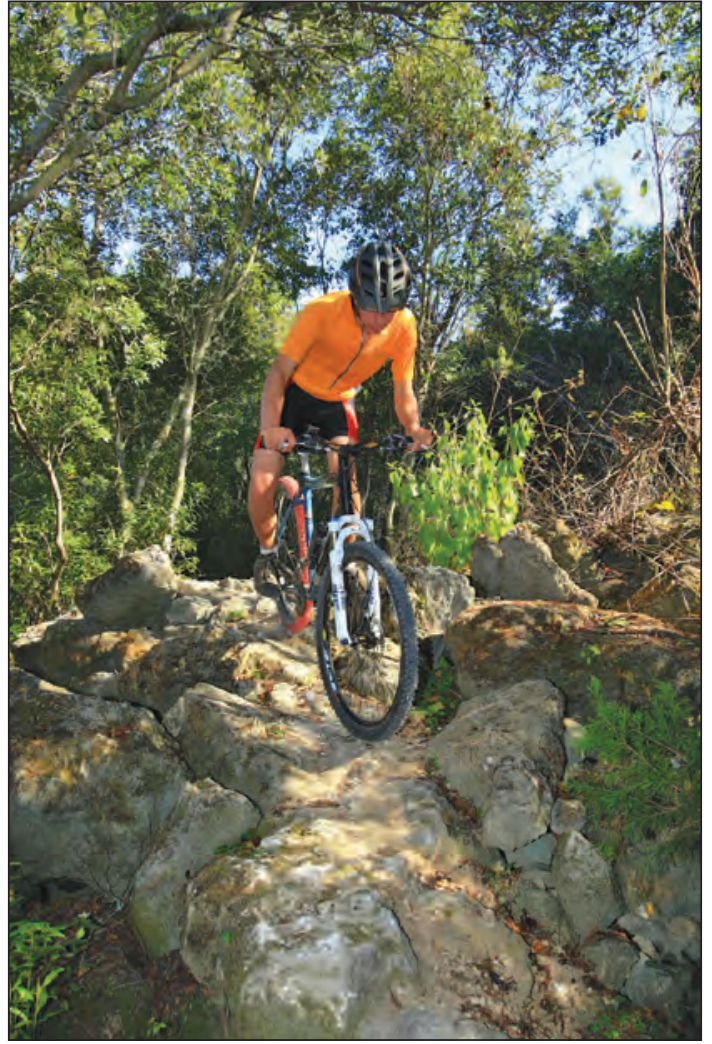

In many areas the limestone of the Upper Floridan aquifer crops out (is exposed) at the land surface, forming rocky ledges such as those shown here along the Cross Florida Greenway.

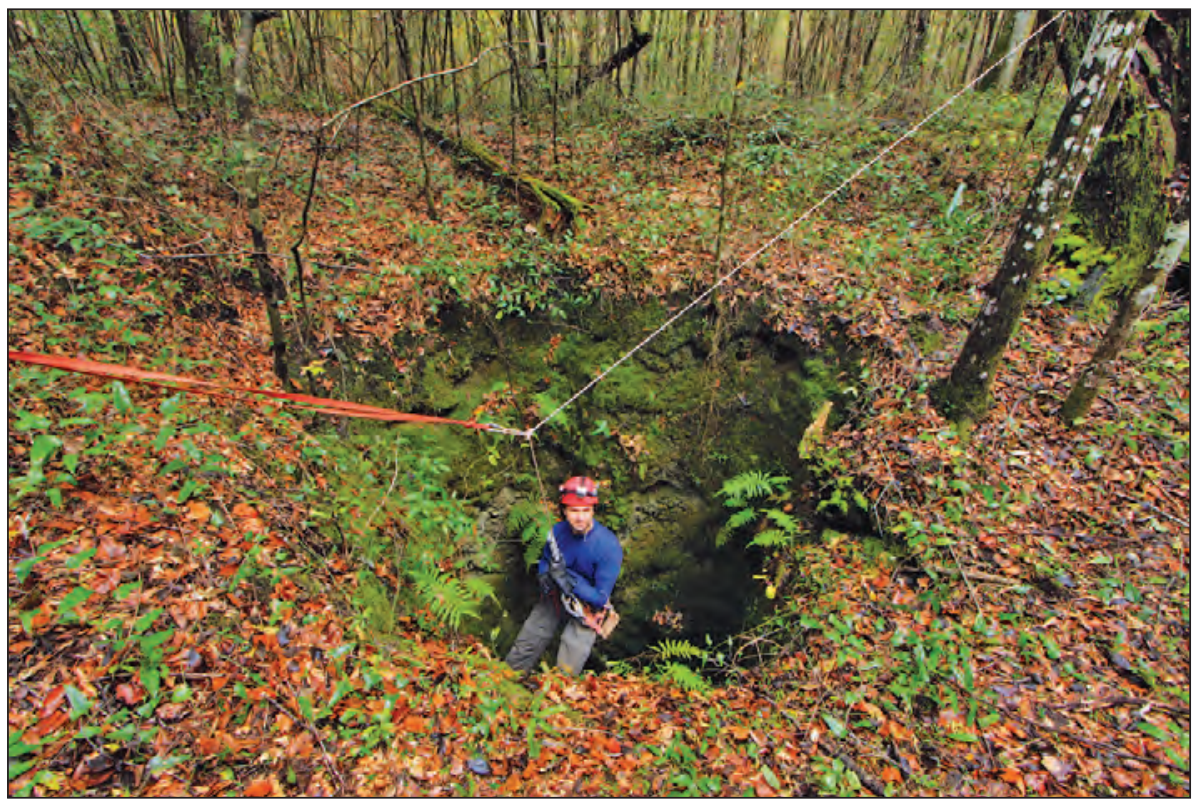

Sinkholes such as this are entryways to the aquifer-water from the land surface can reach the water table with no filtration from overlying soils. 


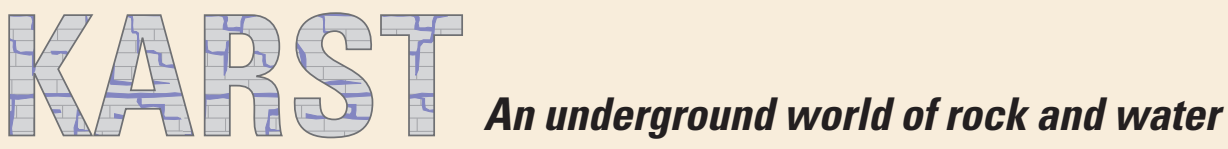

What is karst? Karst describes the distinctive landforms and hydrology that are created when rocks dissolve away. Two common types of rocks - limestone and dolomite - dissolve when they interact with rain or soil water, which are weakly acidic. The dissolution of the rocks creates a network of interconnected openings in the rock (called conduits) that allow large amounts of water to move rapidly into and through the aquifer.

Why is karst important? Karst aquifers provide water for both people and animals. The large underground openings and oxygenated groundwater in karst aquifers provide habitat for rare aquatic species, many of which have yet to be formally identified. Karst aquifers are highly productive, sustainable sources of groundwater, but are vulnerable to contamination. Because of the unique hydrogeologic characteristics of karst conduits, unconventional approaches are required to understand how water and contaminants move through these systems.

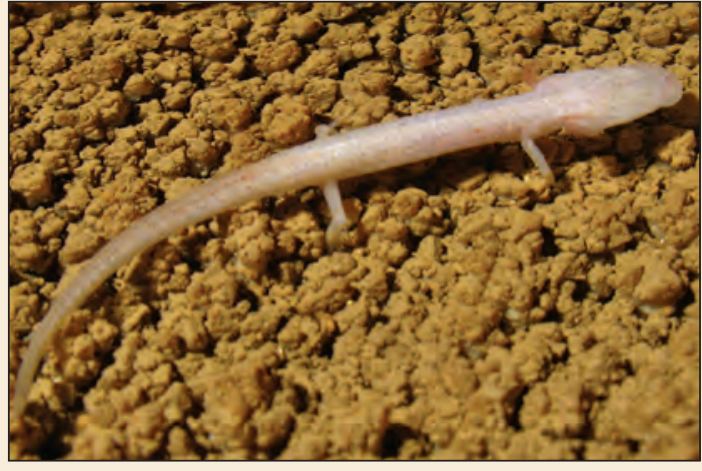

The Georgia Blind Salamander is a protected species in Georgia and Florida that only lives in cave waters of the Floridan aquifer.

How does karst form? The process of creating karst, or karstification, starts when water $\left(\mathrm{H}_{2} \mathrm{O}\right)$ in rainfall interacts with carbon dioxide $\left(\mathrm{CO}_{2}\right)$ in the atmosphere to create carbonic acid $\left(\mathrm{H}_{2} \mathrm{CO}_{3}\right)$, a weak acid. (The naturally occurring presence of carbonic acid in rainwater is why rain has a $\mathrm{pH}$ of less than 7 .) When carbonate rockslimestone and dolomite-interact with an acid, a little bit of the rock dissolves, releasing calcium ions and $\mathrm{CO}_{2}$.

Initially, water flows through small cracks in the rocks. As the rock along the walls of a crack dissolve, the crack becomes wider-over time, what were originally small fractures or tiny spaces gradually enlarge into openings called conduits.

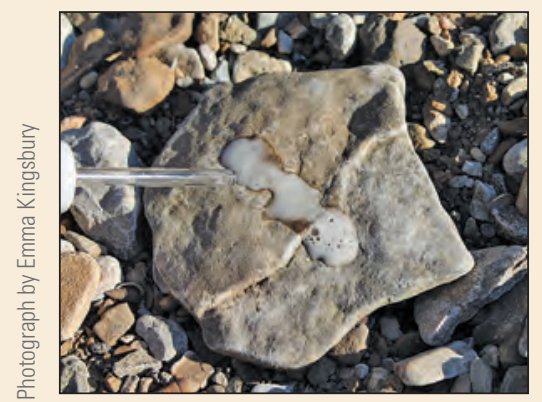

A carbonate rock fizzes when dilute hydrochloric acid dissolves it.
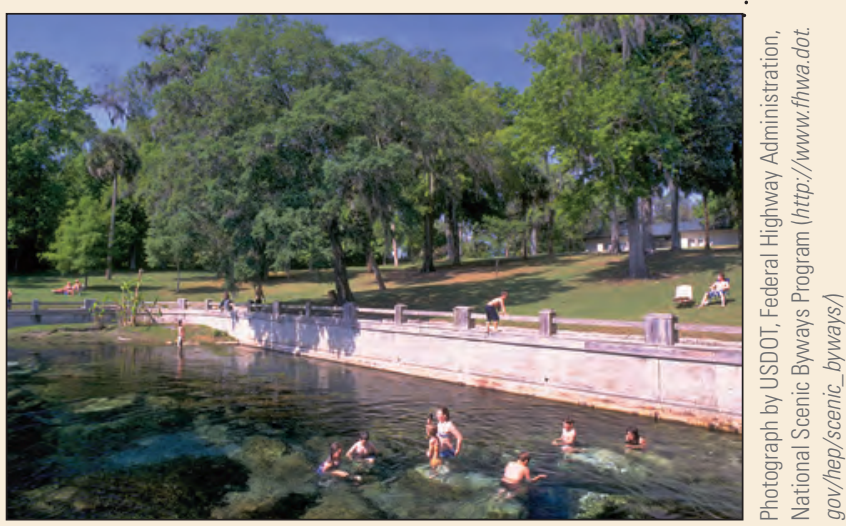

Large amounts of groundwater discharge at crystal-clear springs that are used for recreation and provide habitat for aquatic plants and animals. 


\section{Land Use and Population}

About one-third of the land overlying the Floridan aquifer system is forest land used for the production of paper products and lumber (fig. 3-5). Wetlands cover about 25 percent and agricultural land covers about 20 percent of the land area, followed by 7 percent urban, 4 percent water, and 10 percent other land uses (T.L. Arnold, U.S. Geological Survey, written commun., 2006). Field crops (including cotton, peanuts, corn, soybeans, and wheat) are grown in the central part of the study area, citrus crops are grown in the southern part, and vegetables are grown throughout the study area. Dairy and poultry farms are present in central parts of the study area. In southwestern Georgia and throughout Florida, agriculture and agriculture-related activities play a major role in the economy. ${ }^{(9,10)}$

The population in areas overlying the Floridan aquifer system increased from less than 10 million people in 1970 to more than 22 million people in 2005. The highly populated areas that rely on the Floridan aquifer system are located in northern and coastal parts of Florida and coastal Georgia, and include the cities of Savannah, Ga., and Jacksonville, Orlando, Tampa, St. Petersburg, Clearwater, Tallahassee, and Lakeland, Fla. (fig. 3-6).

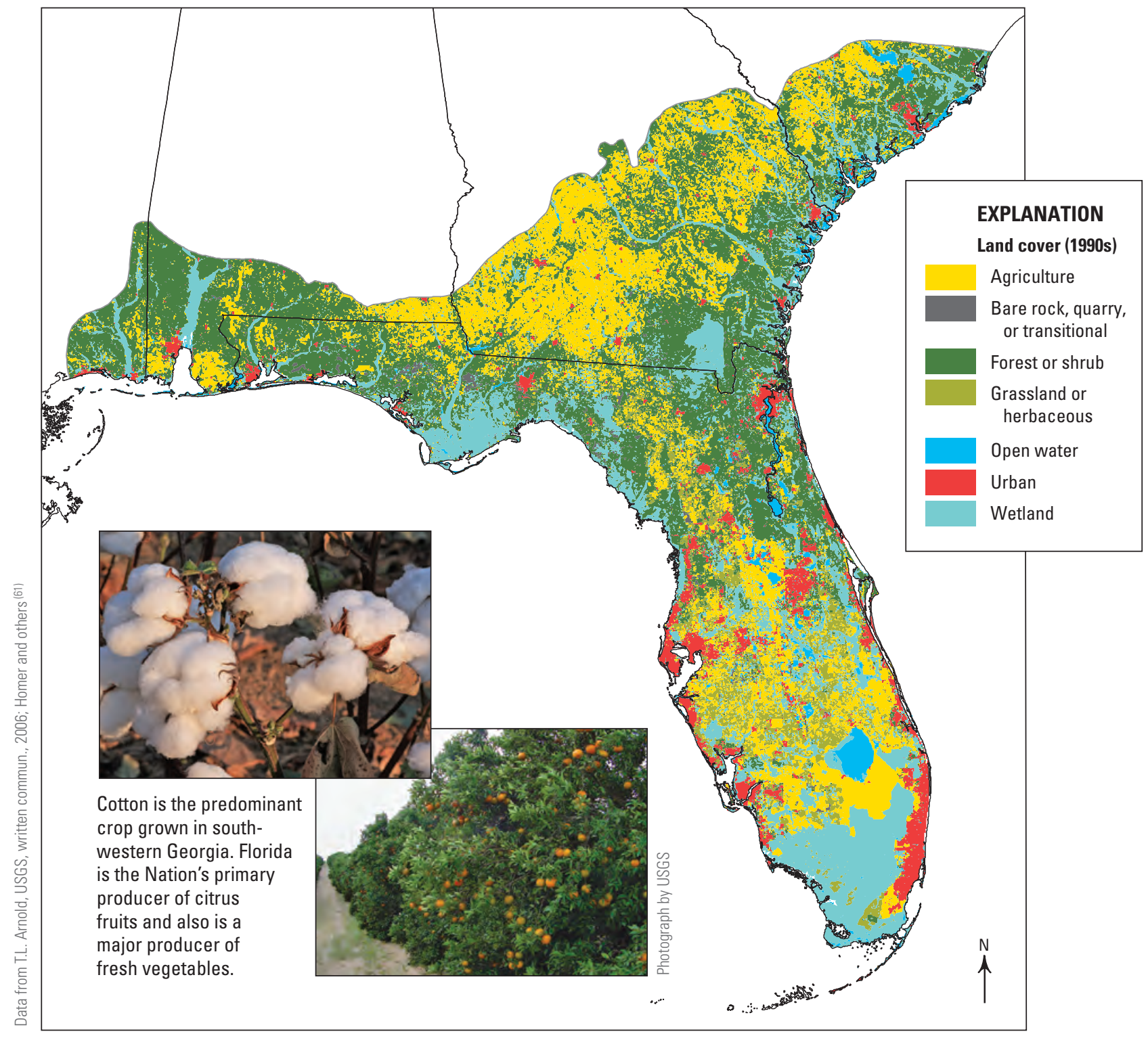

Figure 3-5. The predominant land covers overlying the Upper Floridan aquifer include forests, wetlands, and the combination of agricultural and urban areas. Agricultural land use is concentrated in southwest Georgia and central Florida. 


\section{Water Use}

Surficial aquifers are used primarily for domestic or private household water supply or in areas where the Floridan aquifer system is nonpotable or too deep to be used economically. ${ }^{(11)}$ Total groundwater withdrawals from the surficial aquifers in Florida in 2005 were $532 \mathrm{Mgal} / \mathrm{d}$; ${ }^{(1)}$ water use estimates for the surficial aquifers are not available for Georgia and South Carolina. Withdrawals from surficial aquifers in most of the counties in Florida were less than $20 \mathrm{Mgal} / \mathrm{d}$. Groundwater withdrawals from surficial aquifers greater than $50 \mathrm{Mgal} / \mathrm{d}$ occurred only in southern Florida. In these areas, the underlying Floridan aquifer system is not used for drinking water (public supply and domestic uses), and the surficial aquifers are the primary source of drinking water.

Nearly 10 million people relied on the Floridan aquifer system for their drinking-water supplies in 2000; of these, about 1.6 million people obtained their drinking water from domestic wells. ${ }^{(12)}$ Most of the groundwater withdrawn from the Floridan aquifer system for drinking water is from the Upper Floridan aquifer. The largest withdrawals are in central Florida and along the coast in Georgia and South Carolina (fig. 3-6). This important aquifer system also supports agriculture, industry, and tourism.

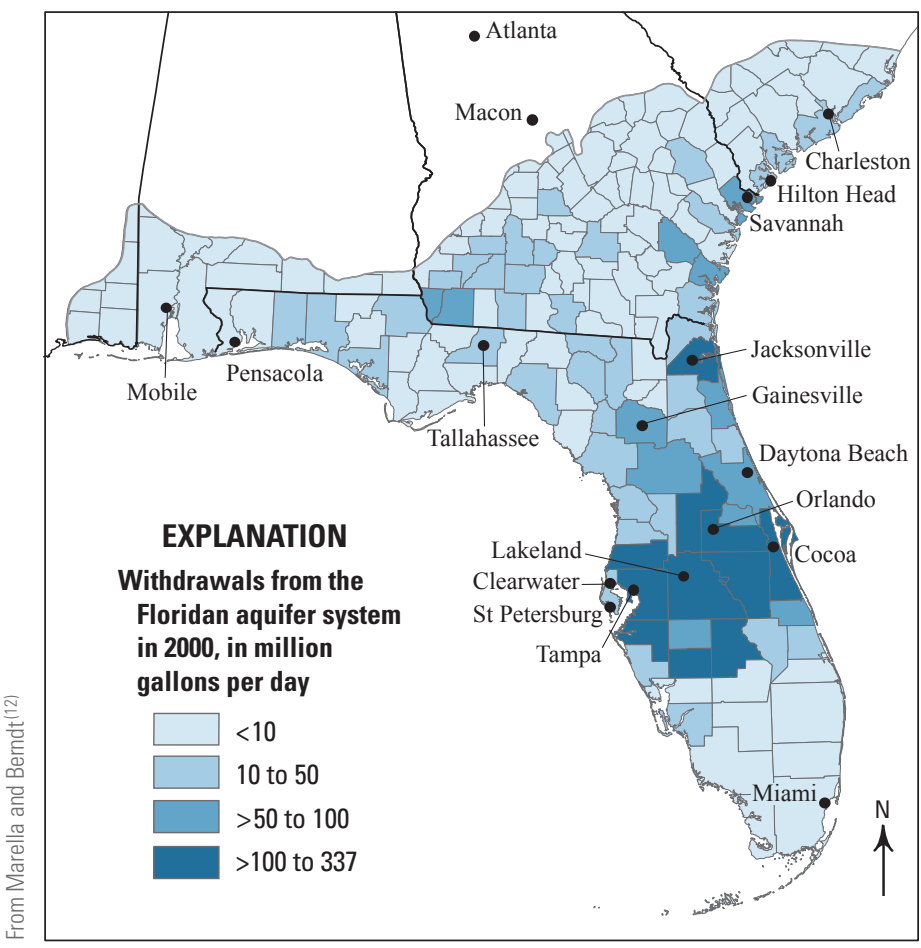

Figure 3-6. The Floridan aquifer system is the source of drinking-water supply for about 10 million people, including the cities of Savannah, Georgia, and Jacksonville, Orlando, Tampa, St. Petersburg, Clearwater, Tallahassee, and Lakeland, Florida. Withdrawals are highest in central Florida where withdrawals for both drinking water and irrigation are greatest.
About 90 percent of the water withdrawn from the Floridan aquifer system is obtained from the Upper Floridan aquifer, which contains potable water in most areas. Localized contamination of the Upper Floridan aquifer, however, has forced water suppliers in some areas to obtain water from the Lower Floridan aquifer. In central and northeastern Florida, water from the Lower Floridan aquifer is potable, but in most other areas the water does not meet drinking-water standards because of high chloride concentrations. ${ }^{(13)}$ In some areas, desalination of brackish groundwater and surface water is a supplemental source of water supply, providing as much as $515 \mathrm{Mgal} / \mathrm{d} .^{(14)}$

Use of the Floridan aquifer system has increased substantially since the mid-1900s - withdrawals of water increased from $630 \mathrm{Mgal} / \mathrm{d}$ in 1950 to $4,020 \mathrm{Mgal} / \mathrm{d}$ in $2000^{(12)}$ (fig. 3-7). Withdrawals for irrigation account for nearly half of that increase - from $90 \mathrm{Mgal} / \mathrm{d}$ in 1950 to $1,950 \mathrm{Mgal} / \mathrm{d}$ in 2000 . Withdrawals for public supply increased from $85 \mathrm{Mgal} / \mathrm{d}$ in 1950 to $1,330 \mathrm{Mgal} / \mathrm{d}$ in 2000 . Nearly 60 percent of that increase occurred from 1980 to 2000, during which the population served by public supply increased from 4.5 million to 8.2 million people. Domestic withdrawals increased from $45 \mathrm{Mgal} / \mathrm{d}$ in $1950^{(4)}$ to $166 \mathrm{Mgal} / \mathrm{d}$ in 2000 .

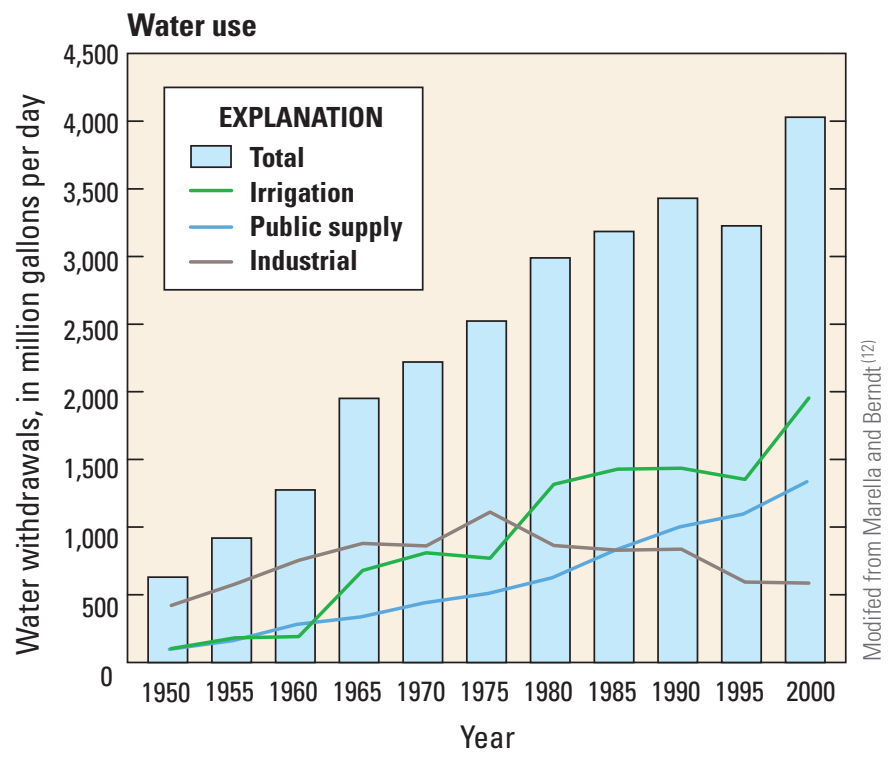

Figure 3-7. Water withdrawals from the Floridan aquifer system increased more than 500 percent from 1950 to 2000, largely as a result of increases in irrigation and public-supply withdrawals. Irrigation is most extensive in Florida and southwestern Georgia. 
In Georgia, agriculture is most extensive in the southwestern part of the State, and irrigation has increased with the introduction of center pivot systems in the 1970s. ${ }^{(15)}$ In 2004, irrigation was used on almost 40 percent of the cropland in the study area in Georgia, which has greatly increased crop productivity and helped agriculture play a major role in the regional economy. ${ }^{(9)}$ Crop types planted in the study area have changed from a mostly corn and peanut rotation in the 1970s to mostly cotton and peanuts. ${ }^{(15)}$

Large quantities of groundwater withdrawals from the Floridan aquifer system have caused extensive waterlevel drawdowns and saltwater intrusion in several areas.
Near Jacksonville, Fla., and Savannah, Ga., water levels have declined at an average rate of up to $0.5 \mathrm{ft}$ per year since $1950,{ }^{(16)}$ and well fields have been relocated farther inland or have been supplemented with surface water. ${ }^{(17)}$

Along the coasts of Georgia and South Carolina, high chloride concentrations in groundwater are attributed to intrusion of seawater caused by large groundwater withdrawals in the Savannah and Hilton Head Island, S.C., areas. ${ }^{(16)}$ Other areas have limited withdrawals because of elevated chloride concentrations or the potential for saltwater intrusion, including the central east and west coasts of Florida ${ }^{(13,16)}$ and the coast of Georgia. ${ }^{(18)}$

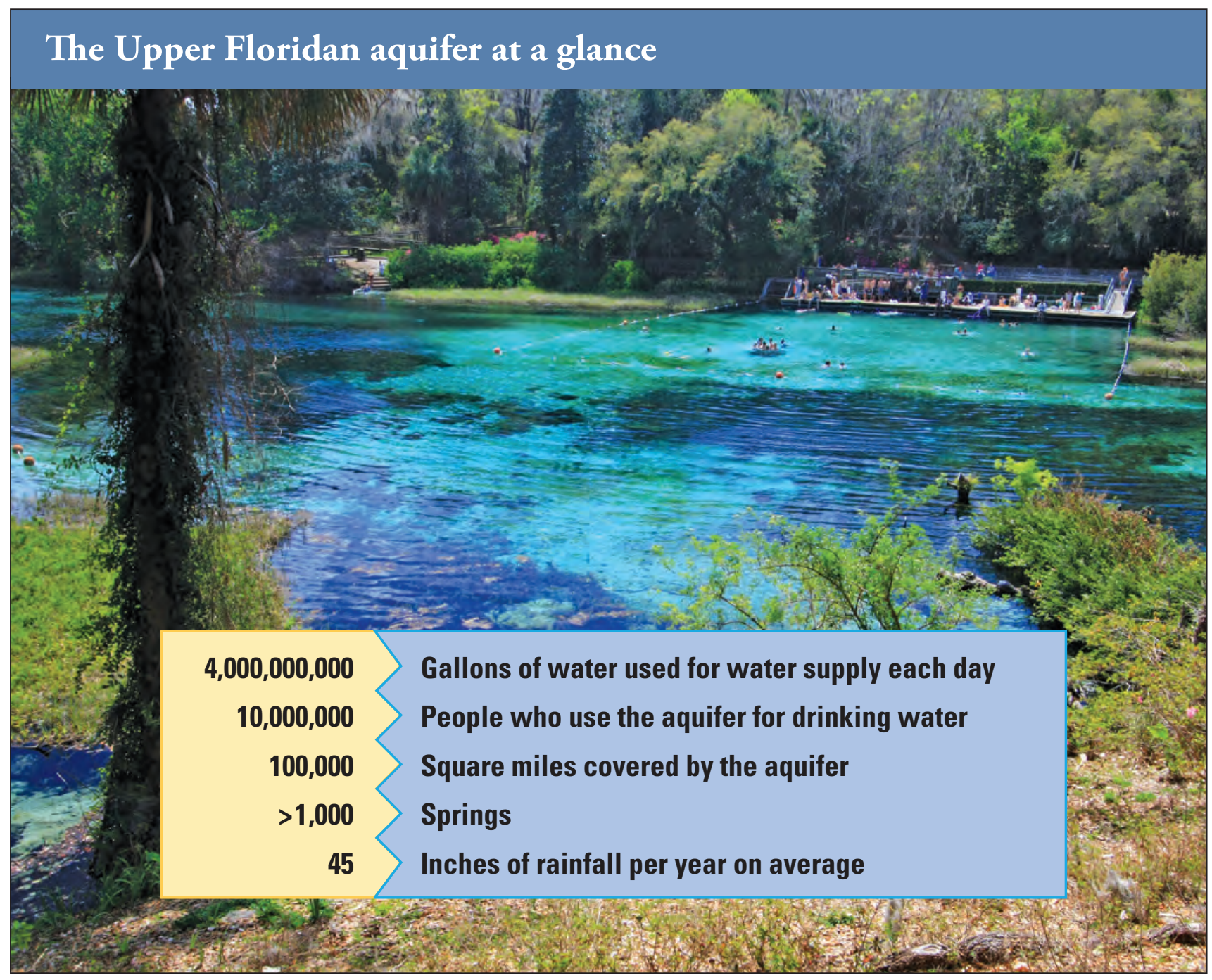




\section{Chapter 4: Natural Processes and Human Activities That Affect Groundwater Quality}

$\mathrm{T}$

The absence or presence of a confining layer controls the susceptibility of the Upper Floridan aquifer to contamination. Where there is no confining layer, water moves through the overlying surficial aquifers directly into the Upper Floridan aquifer. Where a confining layer separates the surficial aquifers from the Upper Floridan aquifer, the confining layer protects the groundwater in the Upper Floridan aquifer from sources of contamination at the land surface. High-volume pumping for public water supply and agricultural uses can cause water from the surficial and Upper Floridan aquifers to mix, changing the geochemical conditions and affecting contaminant concentrations.

This chapter summarizes and explains the hydrologic and geochemical processes and human activities that affect the movement and quality of groundwater in the Upper Floridan aquifer and overlying surficial aquifers.

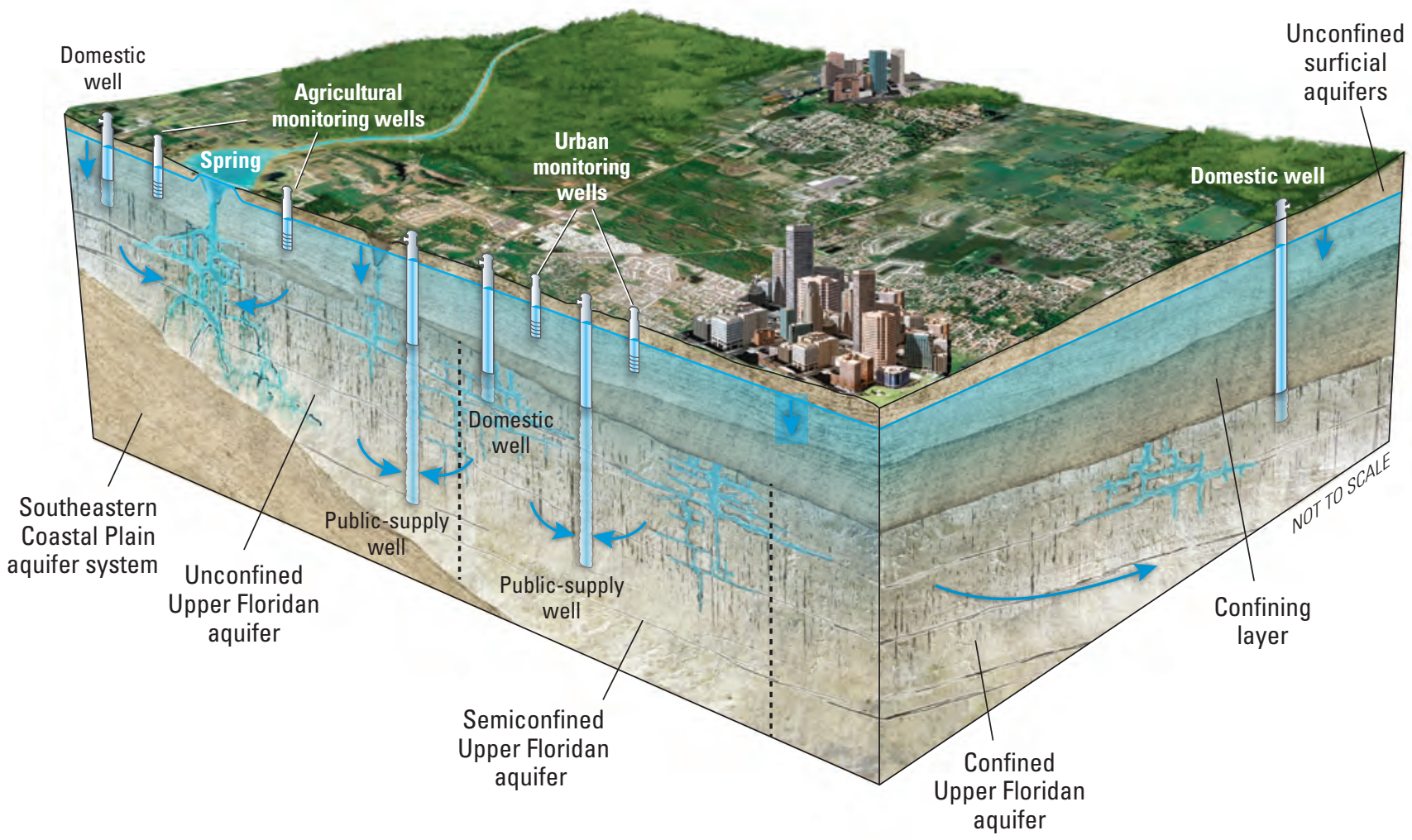

Idealized geologic diagram showing the confining layer that separates the Upper Floridan and surficial aquifers and plays an important role in determining water quality in the Upper Floridan aquifer. 


\section{Karst Features Provide Pathways for Rapid Movement of Water and Contaminants}

In parts of the Upper Floridan aquifer that are unconfined or semiconfined (fig. 3-3), surface water recharges the aquifer through karst features, such as sinkholes and disappearing streams. The groundwater flows through conduits and caves that have formed within the carbonate rocks of the aquifer and discharges to wells, springs, and streams. Flow through conduits is similar to water flowing through a pipe, and large amounts of water can move through the aquifer very quickly - in weeks, days, or even hours. Such flow characteristics are unique to karst aquifers and have fundamental implications for water quality. Water that recharges the aquifer through sinkholes or swallow holes in streambeds enters the aquifer directly, without the filtration by soils that normally would remove some of the bacteria and other contaminants in surface runoff. Once in the aquifer, there is little potential for contaminants in groundwater that moves through conduits to be removed by sorption (adhesion) to rocks, because the volume of water is large relative to the rock surfaces that the water contacts. Rapid groundwater flow through the aquifer allows little time for contaminants to break down or for bacteria to die off — as a result contaminants can be transported quickly to wells or springs. In addition, the hydrology of karst is such that standard approaches for characterizing groundwater flow and contaminant transport commonly cannot be applied. For example, the exact location and dimensions of conduits are largely unknown, so prediction of where and when contaminated water will discharge from the aquifer is problematic.

\section{Unconfined Aquifers Are Vulnerable to Contamination From Human Activities}

Groundwater typically is young in unconfined aquifers with shallow depths to water, such as the surficial aquifers that overlie the Upper Floridan aquifer. That is, the water has recharged the aquifer within the past 60 years, potentially transporting chemicals such as fertilizers and pesticides with it. The Upper Floridan aquifer also is vulnerable to contamination from these chemicals because, where unconfined, the aquifer is hydrologically connected to the surficial aquifers. In some areas, the Upper Floridan aquifer is directly connected to the land surface by sinkholes and disappearing streams. Urban and agricultural runoff, application of treated sewage to spray fields, manure applications to cropland, and septic tanks all are sources of nitrate and organic chemicals at the land surface. ${ }^{(19,20)}$

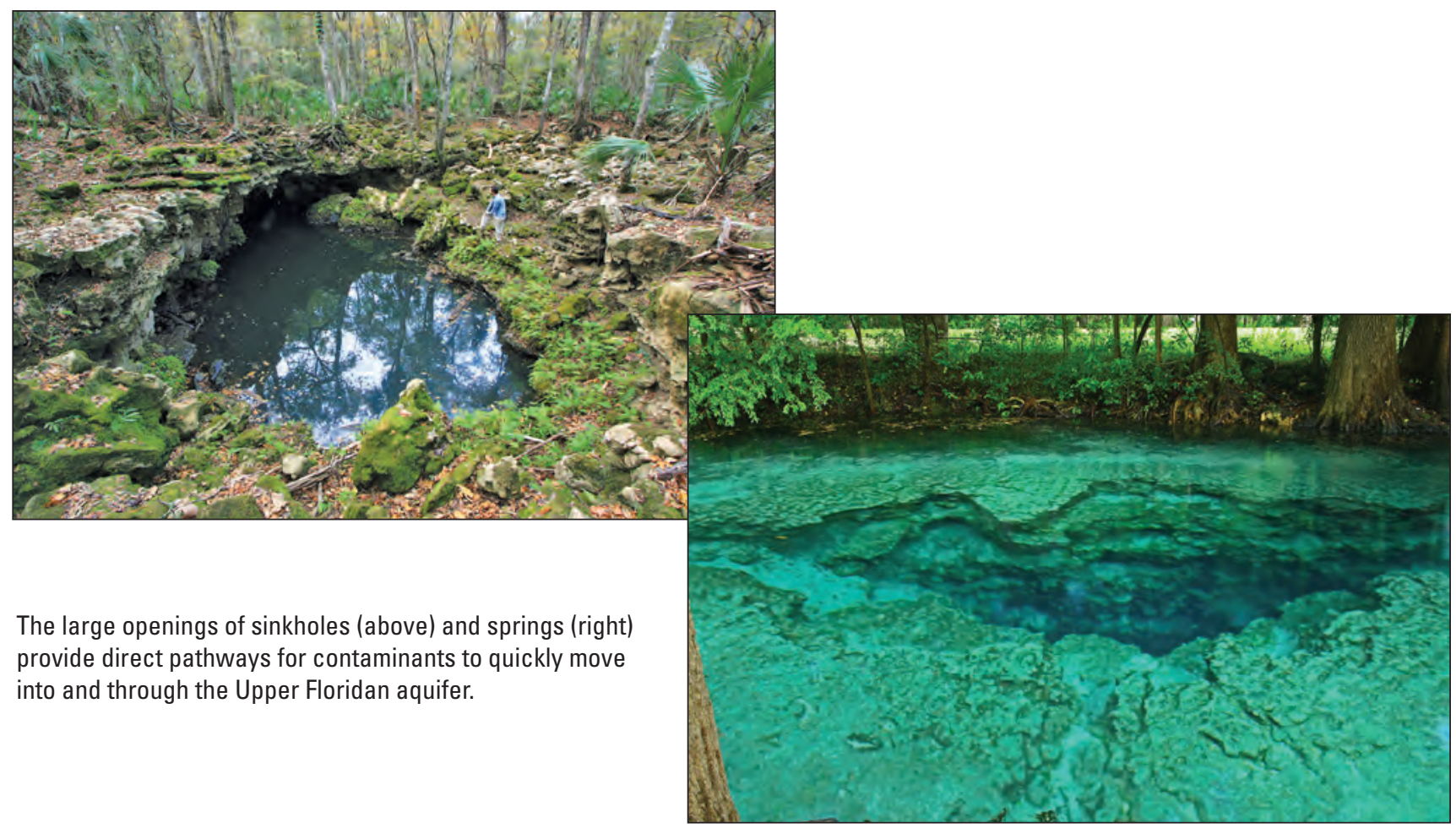




\section{The Presence or Absence of Oxygen in Groundwater Affects the Occurrence of Some Contaminants}

The amount of oxygen in groundwater determines the redox condition of the water, which affects groundwater quality (see sidebar, How do redox reactions work? p. 28). Most groundwater in the surficial aquifers and unconfined parts of the Upper Floridan aquifer is oxic (dissolved-oxygen concentration at least $0.5 \mathrm{mg} / \mathrm{L}$ ) (fig. 4-1). In oxic groundwater, nitrate is stable and is the primary form of nitrogen. In contrast, where a confining layer is present, recharge rates commonly are slow - as a result groundwater becomes anoxic (dissolved-oxygen concentration $<0.5 \mathrm{mg} / \mathrm{L}$ ) as the dissolved oxygen gradually is consumed by microbial activity in the aquifer. Most groundwater in semiconfined and confined areas of the Upper Floridan aquifer is anoxic. In anoxic groundwater, nitrate can be converted to harmless nitrogen gas through denitrification. The presence or absence of dissolved oxygen also is an important control on the solubility of arsenic-bearing minerals in the Upper Floridan aquifer. Some of these minerals are unstable under oxic conditions and can dissolve, releasing arsenic into the groundwater, whereas other arsenic-bearing minerals are unstable under anoxic conditions.
Redox conditions in surficial aquifers

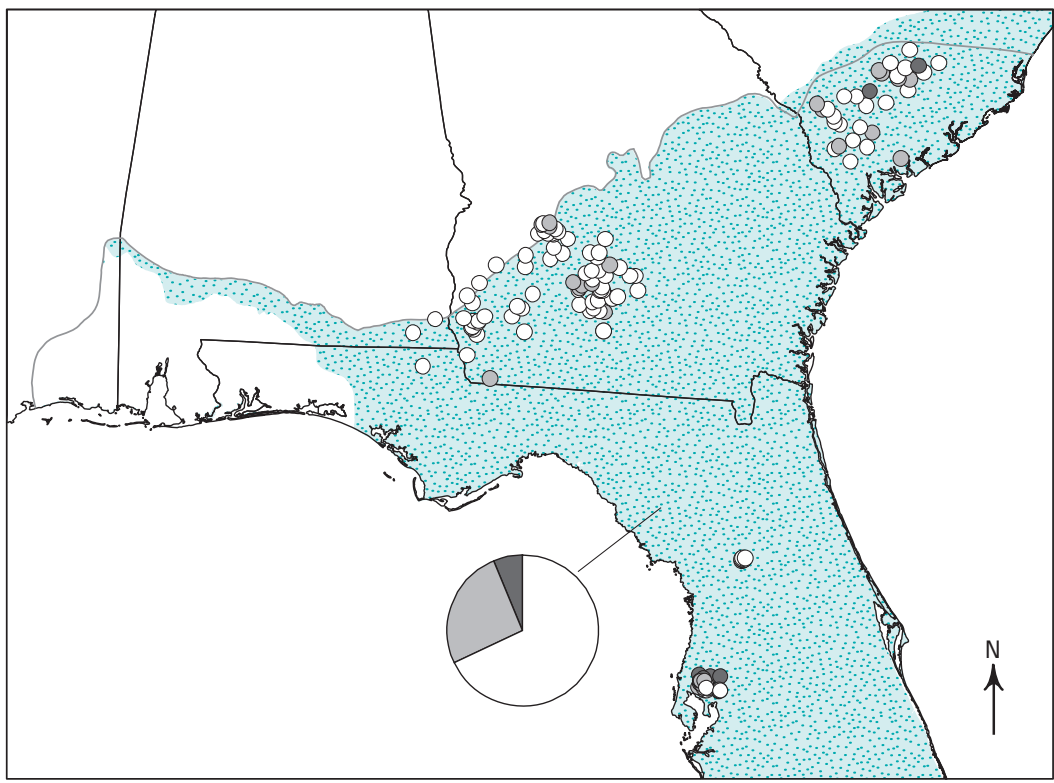

Redox conditions in the Upper Floridan aquifer

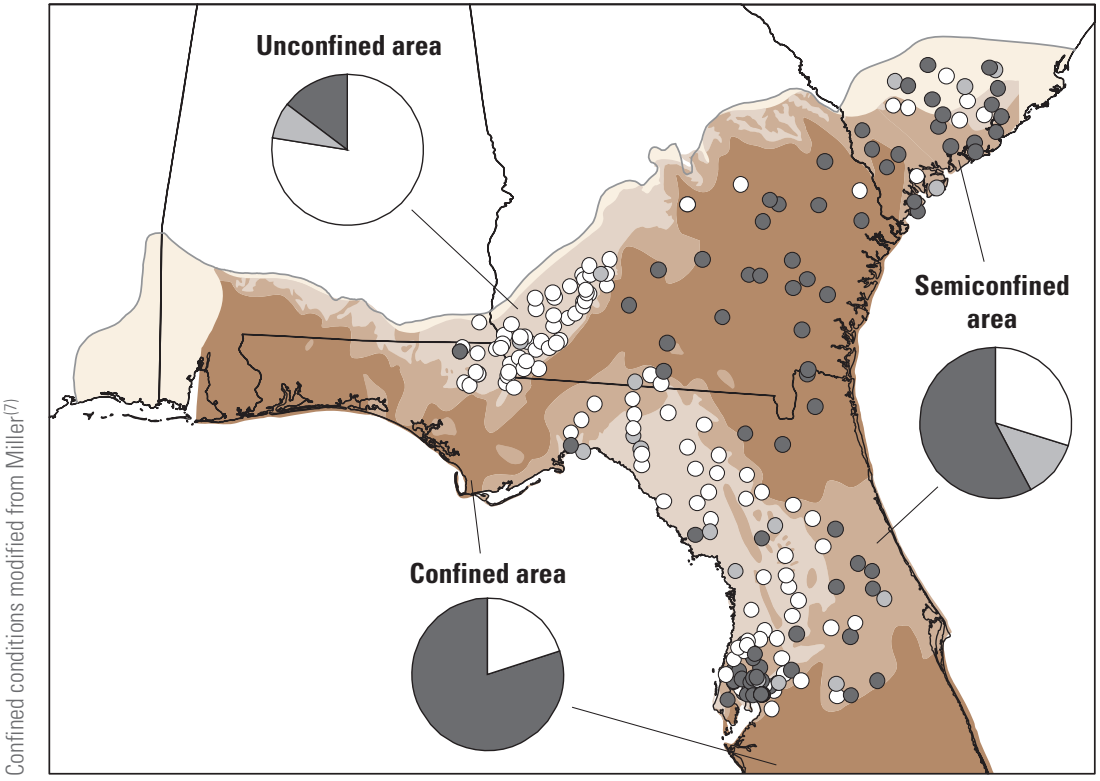

Figure 4-1. The redox condition (oxic or anoxic) of the groundwater controls the concentrations of some contaminants, mainly nitrate and arsenic. Groundwater in the surficial aquifers and unconfined parts of the Upper Floridan aquifer mostly is oxic (containing at least $0.5 \mathrm{mg} / \mathrm{L}$ dissolved oxygen) and in confined parts of the Upper Floridan aquifer mostly is anoxic (containing less than $0.5 \mathrm{mg} / \mathrm{L}$ dissolved oxygen).

\section{EXPLANATION}

Surficial aquifers (includes local surficial aquifers and surficial aquifer system)

Confined condition for Upper Floridan aquifer

Unconfined

Semiconfined (confining layer $<100$ feet thick or breached) Confined Not mapped

Redox condition

Oxic

Mixed

Anoxic 


\section{How do redox reactions work?}

Reduction/oxidation (redox) processes require one chemical species that donates electrons and another chemical species that accepts those electrons. As a chemical species donates electrons it is "oxidized," and as the other species accepts electrons it is "reduced." Redox processes typically are facilitated by microbes (bacteria), which use the energy produced by the processes. In groundwater, organic carbon is the most common electron donor. If dissolved oxygen is present, it is the preferred electron acceptor, because reduction of dissolved oxygen produces more energy than reduction of other chemical species that commonly occur in groundwater. The atmosphere is the source of the dissolved oxygen, so the redox conditions in an aquifer near where recharge occurs usually are oxic (defined here as having a concentration of dissolved oxygen of at least $0.5 \mathrm{mg} / \mathrm{L}$ ).

\begin{tabular}{c|c|c|c|}
\hline Oxic & \multicolumn{3}{c|}{ Anoxic } \\
\hline Oxygen & Nitrate & Manganese Iron Sulfate & Carbon dioxide \\
\hline \multicolumn{4}{|c|}{ Order of consumption of electron acceptors } \\
\hline Oxic & $\begin{array}{c}\text { Mildly } \\
\text { reducing }\end{array}$ & $\begin{array}{c}\text { Strongly } \\
\text { reducing }\end{array}$ & $\begin{array}{c}\text { Very strongly } \\
\text { reducing }\end{array}$ \\
\hline
\end{tabular}

As groundwater moves through the aquifer along a flow path, the dissolved oxygen in the groundwater gradually is consumed by redox processes. Once all of the dissolved oxygen is consumed, other chemical species can accept electrons and become reduced. If nitrate is present, it will become the preferred electron acceptor until it in turn is completely consumed. This pattern continues, with manganese, iron, sulfate, and finally carbon dioxide acting as electron acceptors until they are consumed, in that order. This order of use of electron acceptors has important implications for the preservation, degradation, and even production of contaminants in groundwater. Because redox reactions occur in a sequence, it can take a long time for strongly reducing conditions to develop. For this reason, anoxic groundwater commonly is older than oxic groundwater, and, within the anoxic category, strongly reducing groundwater commonly is older than mildly reducing groundwater.

From a water-quality perspective, denitrification - the reduction of nitrate to nitrogen gas -is one of the most important redox processes that occurs in groundwater. Nitrate is a concern for human health and, where it discharges to surface water, can impair aquatic communities. Conversion of nitrate by denitrification to harmless nitrogen gas, the same gas we breathe in the atmosphere, is the primary way that nitrate is removed from water.

\section{High-Volume Pumping for Water Supply Can Alter Geochemical Conditions and Increase the Vulnerability of Groundwater to Contamination}

High-volume pumping of groundwater for public supply or agricultural use changes the direction and rate of groundwater flow and may transport contaminants from the land surface and overlying surficial aquifers into the Upper Floridan aquifer (fig. 4-2). High-volume pumping also can change the geochemistry of the groundwater near the pumping well. An influx of oxic groundwater from surficial aquifers into anoxic parts of the Upper Floridan aquifer can cause the redox conditions of groundwater near the pumping well to become mixed. This, in turn, can cause some constituents with geologic sources, such as arsenic, to be released from minerals in the aquifer rocks into the groundwater.

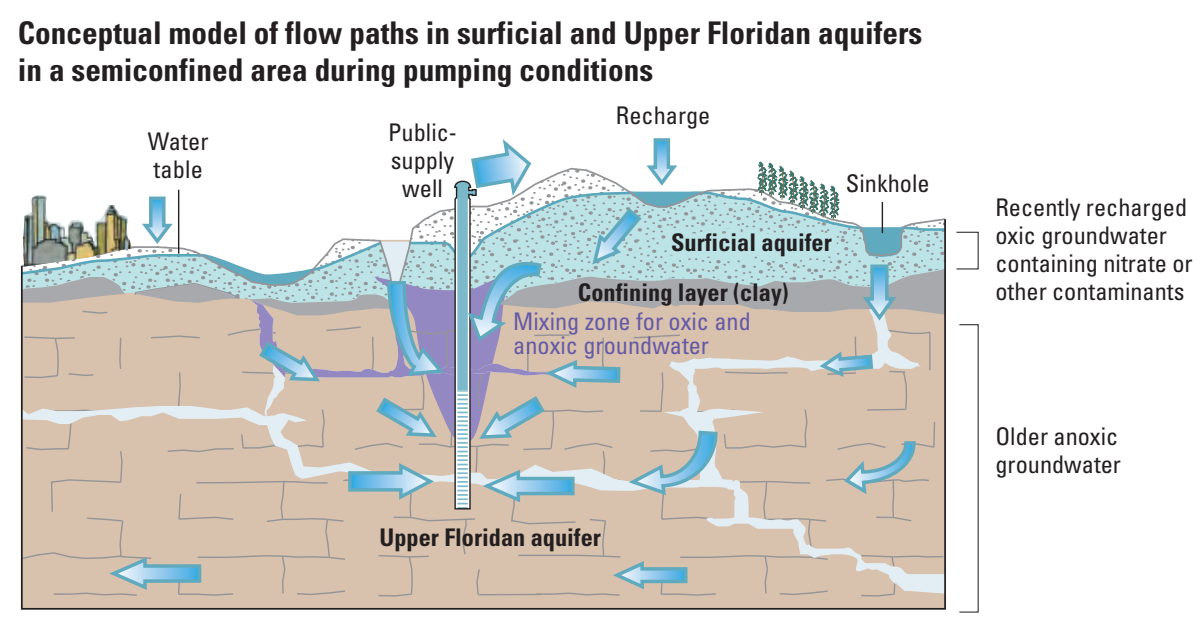

NOT TO SCALE

Figure 4-2. When a public-supply well in a semiconfined part of the Upper Floridan aquifer is pumped, more flow from surficial aquifers reaches the intake to the publicsupply well than would occur where the Upper Floridan aquifer is confined. Because groundwater in the unconfined surficial aquifers has been recharged recently, it is oxic and potentially contains contaminants from land surface. Large withdrawals for publicsupply wells can cause changes in the redox conditions in the Upper Floridan aquifer and also allow contaminants from the surface to move into the public drinking-water supply. 


\section{Chapter 5: Quality of the Groundwater Resource Used for Drinking}

7 he Upper Floridan aquifer is the principal source of drinking water for about 10 million people, and the quality of water in the Floridan aquifer system is among the best in the Nation. Only 4 percent of drinkingwater wells sampled contained a contaminant that exceeded a human-health benchmark. Although few contaminants were detected at concentrations of potential human-health concern in the Upper Floridan aquifer, elevated concentrations of nitrate and the occurrence of pesticides in parts of the surficial aquifers indicate that the underlying Upper Floridan aquifer is vulnerable to contamination where it is recharged by water from the surficial aquifers.
This chapter provides a summary of constituents that were detected at a concentration greater than or near a humanhealth benchmark from drinking-water supply wells tapping the Upper Floridan aquifer and nondrinking-water wells in the overlying surficial aquifer. 


\section{Few Contaminants Were Detected at Concentrations That Exceeded a Human- Health Benchmark}

Two constituents derived from geologic sourcesradon-222 (radon) and strontium - were measured at a concentration greater than their human-health benchmark in 1 percent or more of drinking-water wells in the Upper Floridan aquifer (table 5-1). Radon concentrations in groundwater are determined by the uranium and radium content of the rocks that make up the aquifer materials and the physical characteristics of those aquifer materials. ${ }^{(21)}$ When dissolved in water, radon can degas and be inhaled as the water flows from taps and showerheads. The inhalation of radon increases the risks of lung cancer. ${ }^{(22)}$ There is no U.S. Environmental Protection Agency (USEPA) Maximum Contaminant Level (MCL) for radon, but USEPA has proposed an MCL of 300 picocuries per liter $(\mathrm{pCi} / \mathrm{L})$ and a proposed alternative MCL (AMCL) of 4,000 $\mathrm{pCi} / \mathrm{L}$ for radon. ${ }^{(23)}$ About half of the samples from drinking-water wells contained radon at a concentration greater than the proposed MCL; most of these samples were from wells in central Florida. Only about 3 percent of samples contained radon at a concentration greater than the proposed AMCL.
Strontium was detected in all samples from the Upper Floridan aquifer, but was measured at concentrations that exceeded its human-health benchmark of 4,000 micrograms per liter $(\mu \mathrm{g} / \mathrm{L})$ in just 1 percent of samples. Strontium commonly substitutes for calcium in the minerals that make up the limestones and dolomites of the Upper Floridan aquifer, and as a result strontium was commonly present in groundwater. The primary human-health concern for strontium in drinking water is potential adverse effects on bone development and growth during early childhood.

A number of constituents and properties - "nuisance constituents" - can adversely affect water quality for reasons other than human health. Iron, manganese, hardness, total dissolved solids, and several major ions can cause water to taste bad, smell bad, stain plumbing fixtures, corrode pipes, or have other undesirable effects. The USEPA has issued Secondary Maximum Contaminant Levels (SMCLs) as nonmandatory water-quality criteria for nuisance constituents. Six nuisance constituents were measured at a concentration greater than their SMCL in at least one sample from a drinking-water well in the Upper Floridan aquifer. Of these, iron was the most prevalent, exceeding its SMCL in about 15 percent of drinking-water wells sampled in the Upper Floridan aquifer and in similar percentages of monitoring wells in the Upper Floridan and surficial aquifers (table 5-2).

Table 5-1. Two contaminants from geologic sources, radon and strontium, were measured at concentrations greater than humanhealth benchmarks in 1 percent or more of drinking-water wells sampled in the Upper Floridan aquifer. Three other inorganic constituents were found at concentrations within one-tenth of their human-health benchmarks in 10 percent or more of drinking-water wells.

[MCLs are U.S. Environmental Protection Agency (USEPA) Maximum Contaminant Levels (MCLs) for public water supplies; HBSLs are U.S. Geological Survey Health-Based Screening Levels; <, less than; $\mathrm{pCi} / \mathrm{L}$, picocuries per liter; $\mu \mathrm{g} / \mathrm{L}$, microgram per liter; mg/L, milligram per liter]

\begin{tabular}{|c|c|c|c|c|c|c|c|c|c|c|c|}
\hline \multirow{4}{*}{ Contaminant } & \multirow{3}{*}{\multicolumn{2}{|c|}{$\begin{array}{l}\text { Human-health } \\
\text { benchmark }\end{array}$}} & \multirow{2}{*}{\multicolumn{3}{|c|}{$\begin{array}{l}\text { Upper Floridan aquifer } \\
\text { Drinking-water wells }\end{array}$}} & \multirow{2}{*}{\multicolumn{3}{|c|}{$\begin{array}{c}\text { Upper Floridan aquifer } \\
\text { All wells }\end{array}$}} & \multirow{2}{*}{\multicolumn{3}{|c|}{$\begin{array}{c}\text { Surficial aquifer } \\
\text { All wells }\end{array}$}} \\
\hline & & & & & & & & & & & \\
\hline & & & & Frequency & $\begin{array}{l}\text { Frequency } \\
\text { of concen- }\end{array}$ & & Frequency & Frequency & & Frequency & Frequency \\
\hline & Value & Type & $\begin{array}{l}\text { Number } \\
\text { of wells } \\
\text { sampled }\end{array}$ & $\begin{array}{l}\text { greater } \\
\text { than } \\
\text { benchmark } \\
\text { (percent } \\
\text { of wells) }\end{array}$ & $\begin{array}{c}\text { within } \\
10 \text { percent } \\
\text { of bench- } \\
\text { mark } \\
\text { (percent } \\
\text { of wells) }\end{array}$ & $\begin{array}{l}\text { Number } \\
\text { of wells } \\
\text { sampled }\end{array}$ & $\begin{array}{l}\text { greater } \\
\text { than } \\
\text { benchmark } \\
\text { (percent } \\
\text { of wells) }\end{array}$ & $\begin{array}{c}\text { within } \\
10 \text { percent } \\
\text { of bench- } \\
\text { mark } \\
\text { (percent } \\
\text { of wells) }\end{array}$ & $\begin{array}{l}\text { Number } \\
\text { of wells } \\
\text { sampled }\end{array}$ & $\begin{array}{l}\text { greater } \\
\text { than } \\
\text { benchmark } \\
\text { (percent } \\
\text { of wells) }\end{array}$ & $\begin{array}{l}\text { within } \\
10 \text { percent } \\
\text { of bench- } \\
\text { mark } \\
\text { (percent } \\
\text { of wells) }\end{array}$ \\
\hline \multirow{2}{*}{ Radon } & $4,000 \mathrm{pCi} / \mathrm{L}$ & Proposed & 93 & 3 & 45 & 157 & 3 & 41 & 50 & 8 & 62 \\
\hline & $300 \mathrm{pCi} / \mathrm{L}$ & MCLs & 93 & 55 & 95 & 157 & 46 & 97 & 50 & 56 & 100 \\
\hline Strontium & $4,000 \mu \mathrm{g} / \mathrm{L}$ & HBSL & 162 & 1 & 14 & 208 & 2 & 15 & 85 & 0 & 0 \\
\hline Nitrate & $10 \mathrm{mg} / \mathrm{L}$ & MCL & 161 & 0 & 23 & 249 & $<1$ & 33 & 144 & 16 & 58 \\
\hline Dieldrin & $0.002 \mu \mathrm{g} / \mathrm{L}$ & HBSL & 159 & 0 & 0 & 251 & $<1$ & $<1$ & 138 & 1 & 1 \\
\hline
\end{tabular}


Table 5-2. Iron concentrations were greater than the value recommended by USEPA for the aesthetic quality of water in about 15 percent of drinking-water samples in the Upper Floridan aquifer. Concentrations of chloride, fluoride, iron, manganese, sulfate, and dissolved solids were outside the range of values for aesthetic quality of water in less than 5 percent of the drinking-water samples.

[SMCLs are U.S. Environmental Protection Agency (USEPA) Secondary Maximum Contaminant Levels (SMCLs) for public water supplies; mg/L, milligram per liter; $\mu \mathrm{g} / \mathrm{L}$, microgram per liter]

\begin{tabular}{|c|c|c|c|c|c|c|c|c|}
\hline \multirow[b]{3}{*}{ Constituent } & \multirow{2}{*}{\multicolumn{2}{|c|}{ Guideline }} & \multirow{2}{*}{\multicolumn{2}{|c|}{$\begin{array}{l}\text { Upper Floridan aquifer } \\
\text { Drinking-water wells }\end{array}$}} & \multirow{2}{*}{\multicolumn{2}{|c|}{$\begin{array}{c}\text { Upper Floridan aquifer } \\
\text { All wells }\end{array}$}} & \multirow{2}{*}{\multicolumn{2}{|c|}{$\begin{array}{c}\text { Surficial aquifer } \\
\text { All wells }\end{array}$}} \\
\hline & & & & & & & & \\
\hline & Value & Type & $\begin{array}{l}\text { Number } \\
\text { of wells } \\
\text { sampled }\end{array}$ & $\begin{array}{l}\text { Frequency of } \\
\text { concentration } \\
\text { greater than } \\
\text { guideline } \\
\text { (percent } \\
\text { of wells) }\end{array}$ & $\begin{array}{l}\text { Number } \\
\text { of wells } \\
\text { sampled }\end{array}$ & $\begin{array}{l}\text { Frequency of } \\
\text { concentration } \\
\text { greater than } \\
\text { guideline } \\
\text { (percent } \\
\text { of wells) }\end{array}$ & $\begin{array}{l}\text { Number } \\
\text { of wells } \\
\text { sampled }\end{array}$ & $\begin{array}{l}\text { Frequency of } \\
\text { concentration } \\
\text { greater than } \\
\text { guideline } \\
\text { (percent } \\
\text { of wells) }\end{array}$ \\
\hline Chloride & $250 \mathrm{mg} / \mathrm{L}$ & SMCL & 160 & 2 & 244 & 1 & 143 & 0 \\
\hline Fluoride & $2 \mathrm{mg} / \mathrm{L}$ & SMCL & 160 & 2 & 244 & 2 & 143 & 0 \\
\hline Iron & $300 \mu \mathrm{g} / \mathrm{L}$ & SMCL & 160 & 15 & 244 & 18 & 144 & 13 \\
\hline Manganese & $50 \mu \mathrm{g} / \mathrm{L}$ & SMCL & 160 & 4 & 244 & 5 & 144 & 12 \\
\hline Sulfate & $250 \mathrm{mg} / \mathrm{L}$ & SMCL & 160 & 1 & 244 & 2 & 143 & 0 \\
\hline Total dissolved solids & $500 \mathrm{mg} / \mathrm{L}$ & SMCL & 160 & 5 & 244 & 6 & 143 & 0 \\
\hline
\end{tabular}

\section{What is a contaminant?}

Contaminants have a wide range of sources, both manmade and geologic. Most organic chemicals in groundwater that are of concern for human health are manmade. In contrast, most inorganic constituents in groundwater have geologic or other natural sources, although their concentrations in groundwater may be altered by human activities, such as irrigation and groundwater pumping. Some contaminants have both manmade and natural sources. For example, nitrate in groundwater has many natural sources, but nitrate concentrations in groundwater underlying agricultural and urban areas commonly are higher than in other areas because of contributions from sources associated with human activities.

But what exactly is a contaminant? The word means different things to different people. For example, a contaminant is defined by the Safe Drinking Water Act (SDWA) as "any physical, chemical, biological, or radiological substance or matter in water" (see http://www.epw.senate.gov/sdwa.pdf). This broad definition of contaminant includes every substance that may be found dissolved or suspended in water-everything but the water molecule itself. This is not a very practical definition because this would imply that all water is "contaminated." Pure water that has nothing dissolved in it does not occur naturally—not even rainfall is pure water, because it contains, at a minimum, some dissolved gases.

The U.S. Environmental Protection Agency defines a contaminant as "Any physical, chemical, biological, or radiological substance or matter that has an adverse effect on air, water, or soil" (see http://epa.gov/region04/superfund/qfinder/g/ossary.htm/). This definition is more practical and allows both manmade constituents and those with geologic sources in water to be defined as contaminants. However, it does not define what "adverse" means, and what may be adverse in one way might be beneficial in another. In this circular, a contaminant is defined as any physical, chemical, biological, or radiological substance or matter in groundwater that is manmade or that impairs the use of water for its intended purpose. Impairment is determined by comparing a measured concentration to benchmarks or guidelines. By this definition, all manmade compounds, such as pesticides and volatile organic compounds, are contaminants because they do not occur naturally in groundwater. If a constituent with a geologic source, such as arsenic, occurs in drinking water at a concentration above its human-health benchmark, it also is considered a contaminant. 


\section{Human-health benchmarks and other guidelines used in this assessment}

Concentrations of constituents measured for this assessment were compared to human-health benchmarks to place study findings in the context of human health. The benchmarks are threshold concentrations in water above which the concentration of a contaminant in drinking water could adversely affect human health. Human-health benchmarks were available for about two-thirds of the 285 constituents and properties measured for the Principal Aquifer assessments (appendix 2). Two types of human-health benchmarks were used: U.S. Environmental Protection Agency (USEPA) Maximum Contaminant Levels (MCLs) (http://water.epa.gov/drink/contaminants/index.cfm) and U.S. Geological Survey (USGS) Health-Based Screening Levels (HBSLs). MCLs are legally enforceable drinkingwater standards that specify the maximum permissible level of a constituent in water that is delivered to any user of a public water system ${ }^{(59)}$ (values used in this report were current as of February 2012). Although MCLs are used to regulate the quality of drinking water only from public-supply sources, they also are useful for evaluating the quality of water from domestic and monitoring wells. An MCL was available for 53 of the constituents measured. For some constituents for which an MCL has not been established, the USGS, in collaboration with the USEPA and others, developed non-enforceable HBSLs by using standard USEPA methods for establishing drinking-water guidelines and current toxicity information ${ }^{(56,57,58)}$ (values used in this report were current as of February 2012; see http://water.usgs.gov/nawqa/HBSL). An HBSL was available for 135 constituents measured. Radon has neither an MCL nor an HBSL, but two MCLs have been proposed. Copper and lead have USEPA action levels rather than an MCL.

In addition to human-health benchmarks, non-health-based guidelinesSecondary Maximum Contaminant Levels (SMCLs) — were available for some of the constituents measured in this assessment. The SMCLs are non-enforceable guidelines for concentrations of "nuisance" constituents in drinking water that can cause unwanted cosmetic effects, such as skin or tooth discoloration; aesthetic effects, such as unpleasant taste, odor, or color; or technical effects, such as corrosion or sedimentation of plumbing or reduced effectiveness of water treatment. ${ }^{(60)}$

Concentrations greater than one-tenth of a human-health benchmark were used in this assessment to indicate which contaminants occurred, either individually or as mixtures, at concentrations that approach those of potential concern for human health, and to identify contaminants that might warrant additional monitoring and study. The criterion of one-tenth of a benchmark is consistent with various State and Federal practices for reporting contaminant occurrence in groundwater and for identifying contaminants of potential human-health concern (for example, see U.S. Environmental Protection Agency; ${ }^{(54)}$ New Jersey Department of Environmental Protection ${ }^{(55)}$ ).

Screening-level assessments, such as this one, provide perspective on the potential relevance of detected contaminants to human health and can help in planning future studies. ${ }^{(57)}$ They are not designed to evaluate specific effects of

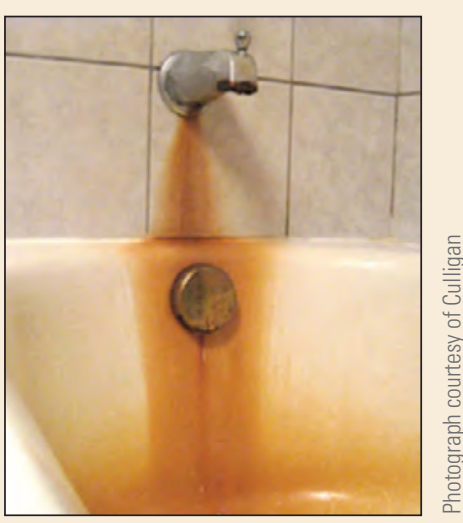

Iron concentrations that exceed the SMCL in household water can result in staining of bathtubs, sinks, and other plumbing fixtures. Elevated iron also can give drinking water a metallic taste or unpleasant odor. contaminants on human health and are not a substitute for comprehensive risk assessments. It is important to note that occurrence of a contaminant at a concentration greater than its benchmark does not mean that adverse effects are certain to occur, because the benchmarks are conservative (protective) and source-water samples were collected prior to any treatment or blending that could alter contaminant concentrations in finished drinking water. There are water-treatment options, such as charcoal filtration, that can be used to lower the concentration of the contaminant to below the benchmark before the water is consumed. 
Nitrate is a Potential Contaminant of Concern for Drinking Water Because of its Widespread Occurrence in Shallow Monitoring Wells in Urban and Agricultural Areas

The occurrence of nitrate at concentrations greater than the background concentration indicates that the Upper Floridan and surficial aquifers are vulnerable to contamination from human activities at the land surface. Almost one-fourth (23 percent) of the samples from drinking-water wells had nitrate concentrations greater than $1 \mathrm{mg} / \mathrm{L}$ as $\mathrm{N}$ (table 5-1; fig. 5-1), which is above the background concentration of $0.1 \mathrm{mg} / \mathrm{L}$ for the Upper Floridan aquifer. ${ }^{(24)}$ The highest nitrate concentrations occurred in the unconfined parts of the Upper Floridan aquifer in southwest Georgia and northcentral Florida where agriculture is the dominant land use. About 32 and 41 percent of samples in urban and agricultural monitoring wells, respectively, in the Upper Floridan and surficial aquifers had nitrate concentrations greater than $1 \mathrm{mg} / \mathrm{L}$ as $\mathrm{N}$.

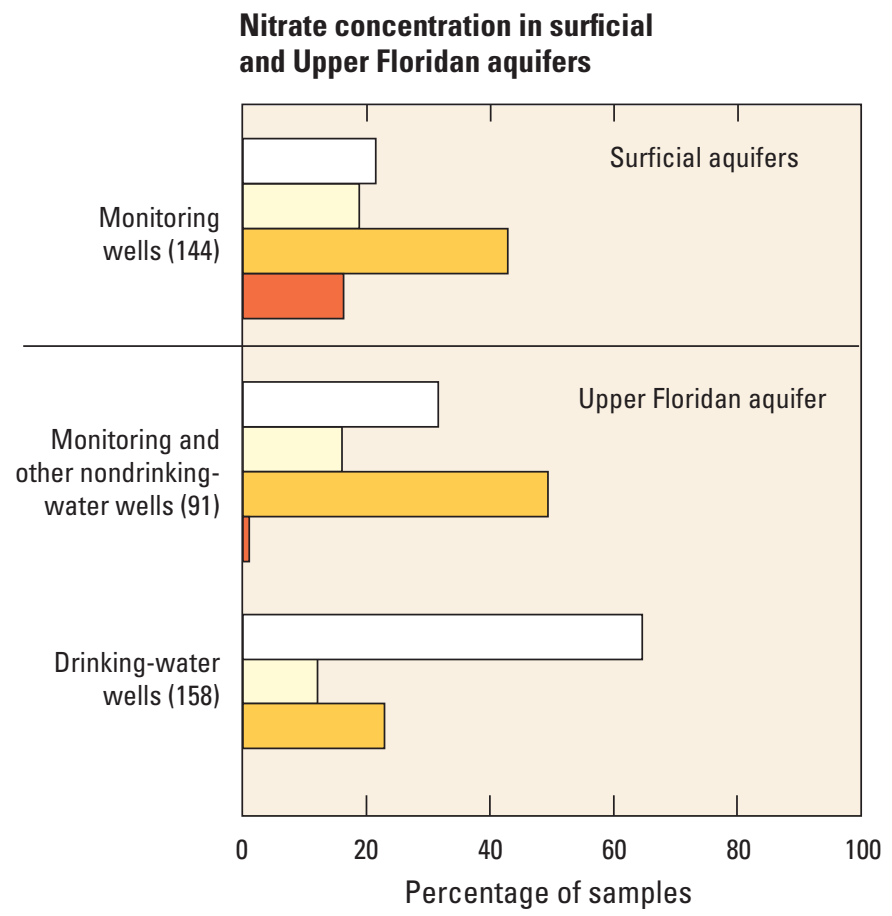

Figure 5-1. Concentrations of nitrate exceeded the human-health benchmark of $10 \mathrm{mg} / \mathrm{L}$ as $\mathrm{N}$ in 16 percent of samples from monitoring wells in surficial aquifers, but in only one sample from a monitoring well in the Upper Floridan aquifer, and in no samples from drinking-water wells.
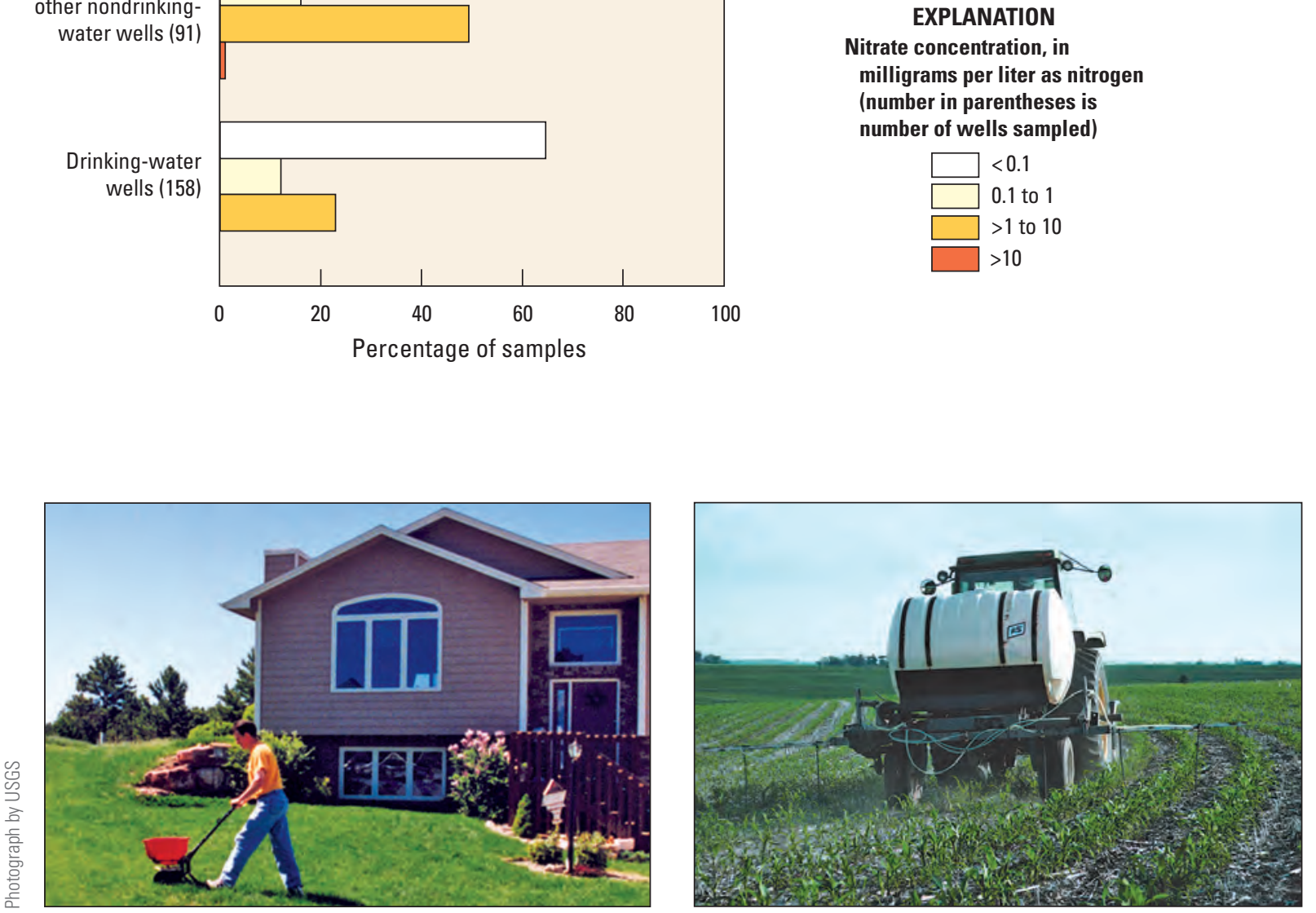

Fertilizer use in urban areas on lawns and turf (above) and in agricultural areas (right) are sources of nitrate to groundwater. 


\section{Low-Level Concentrations of Pesticides and Volatile Organic Compounds Were Detected Frequently}

Dieldrin, an insecticide, was the only pesticide or volatile organic compound (VOC) detected at a concentration greater than a human-health benchmark (table 5-1). Although few benchmarks were exceeded, numerous pesticides and VOCs were detected in both the surficial and Upper Floridan aquifers, and about 20 percent of the 38 pesticides and 18 percent of the 27 VOCs detected were present in more than 10 percent of the samples. The occurrence of these chemicals - which includes herbicides, insecticides, solvents, disinfection by-products, gasoline hydrocarbons and oxygenates, refrigerants, and fumigants - highlights the diverse industrial, urban, and agricultural land uses that can affect groundwater quality.
The most frequently detected pesticides in samples from the surficial and Upper Floridan aquifers were the herbicides atrazine and its degradates (deethylatrazine, hydroxyatrazine, and deisopropylatrazine), metolachlor, prometon, bentazon, and tebuthiuron (fig. 5-2). Most of these herbicides and degradates were detected in about the same percentage of agricultural monitoring wells in the surficial aquifers and public-supply wells in the Upper Floridan aquifer, but concentrations were lower in public-supply wells. Only tebuthiuron, an herbicide with nonagricultural uses, was measured at a concentration above $0.1 \mu \mathrm{g} / \mathrm{L}$ in a public-supply well, whereas seven herbicide compounds were detected above $0.1 \mu \mathrm{g} / \mathrm{L}$ in some agricultural monitoring wells in the surficial aquifers. These commonly detected herbicide compounds were detected much less frequently in domestic wells than in the public-supply wells in the Tampa, Fla., area. This difference likely reflects the larger areas that contribute water to publicsupply wells than to domestic wells and greater use of these herbicides in the contributing areas of public-supply wells.
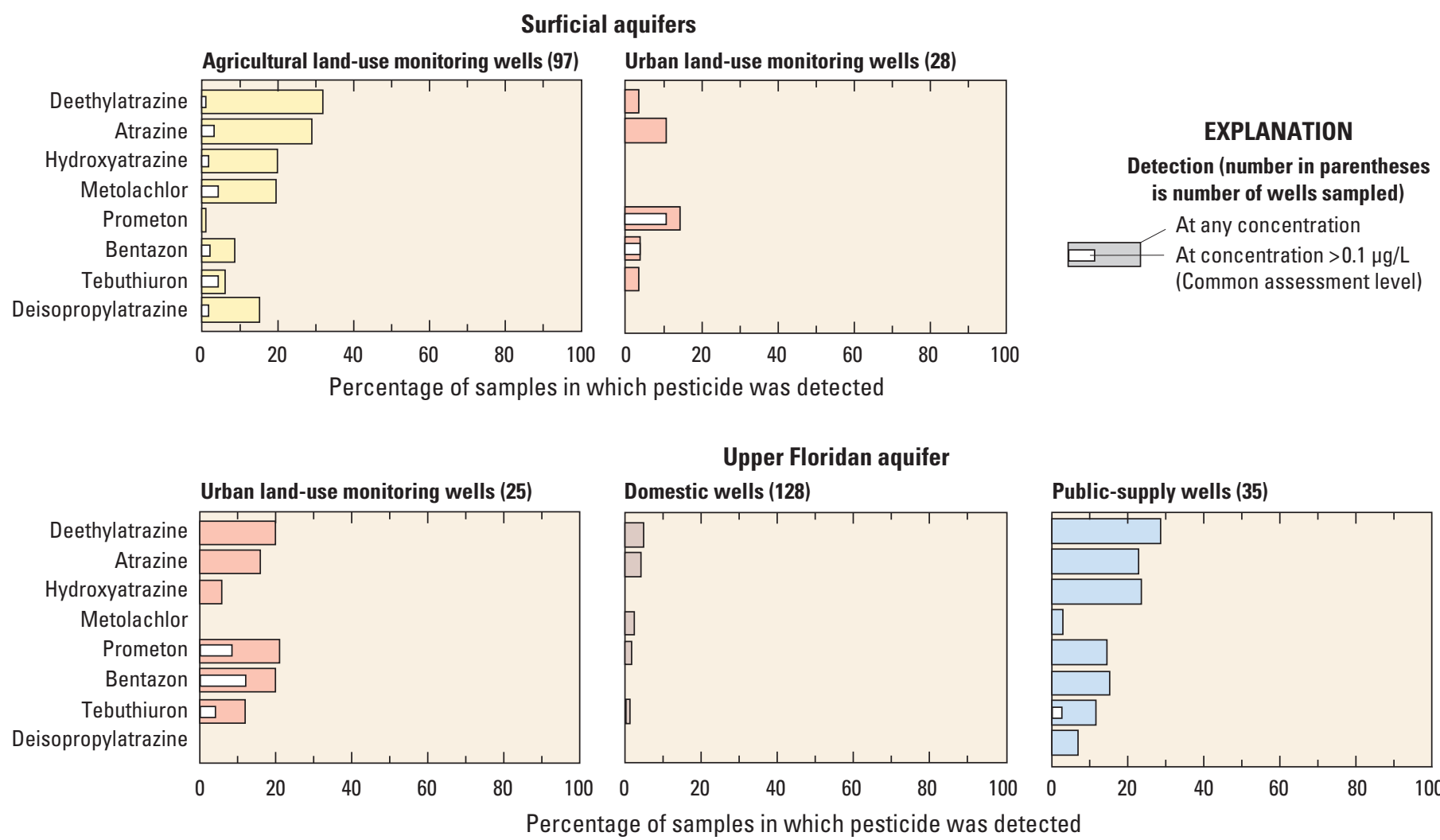

Public-supply wells (35)

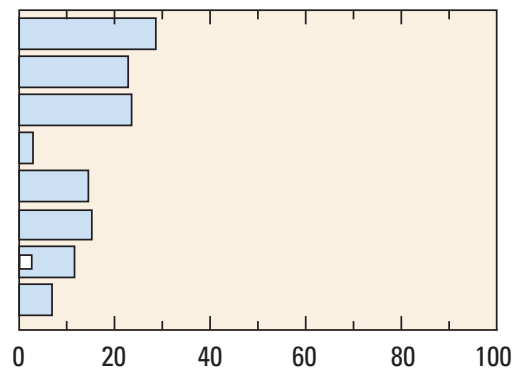

Figure 5-2. The herbicide atrazine and two of its degradation products (deethylatrazine and hydroxyatrazine) were the pesticide compounds most commonly detected in samples from the surficial and Upper Floridan aquifers. Detection frequencies in public-supply wells in the Upper Floridan aquifer were comparable to detection frequencies in monitoring wells, but concentrations were lower. 
The VOCs most frequently detected in the Upper Floridan aquifer were chloroform, carbon disulfide, 1,2-dichloropropane, and tetrachloroethene (also known as perchloroethylene or PCE) (fig. 5-3). Chloroform is a trihalomethane compound that commonly is produced by the chlorination of water and wastewater. Other potential sources of chloroform and other trihalomethanes that might affect water withdrawn from domestic wells are laundry wastewater, which contains bleach, and shock chlorination of wells for disinfection. Chloroform was detected in samples from 44 percent of public-supply wells and 24 percent of domestic wells in the Upper Floridan aquifer and in 32 percent of monitoring wells in urban land-use areas in surficial aquifers. Most of the public-supply wells and urban monitoring wells sampled were located in the Tampa area. Chloroform and carbon disulfide have been detected frequently in groundwater in the Tampa area. ${ }^{(25)}$

The occurrence of pesticides, solvents, disinfection by-products, gasoline hydrocarbons, and fumigants in groundwater highlights the diverse industrial, urban, and agricultural land uses that can affect groundwater quality.

\section{Surficial aquifers}
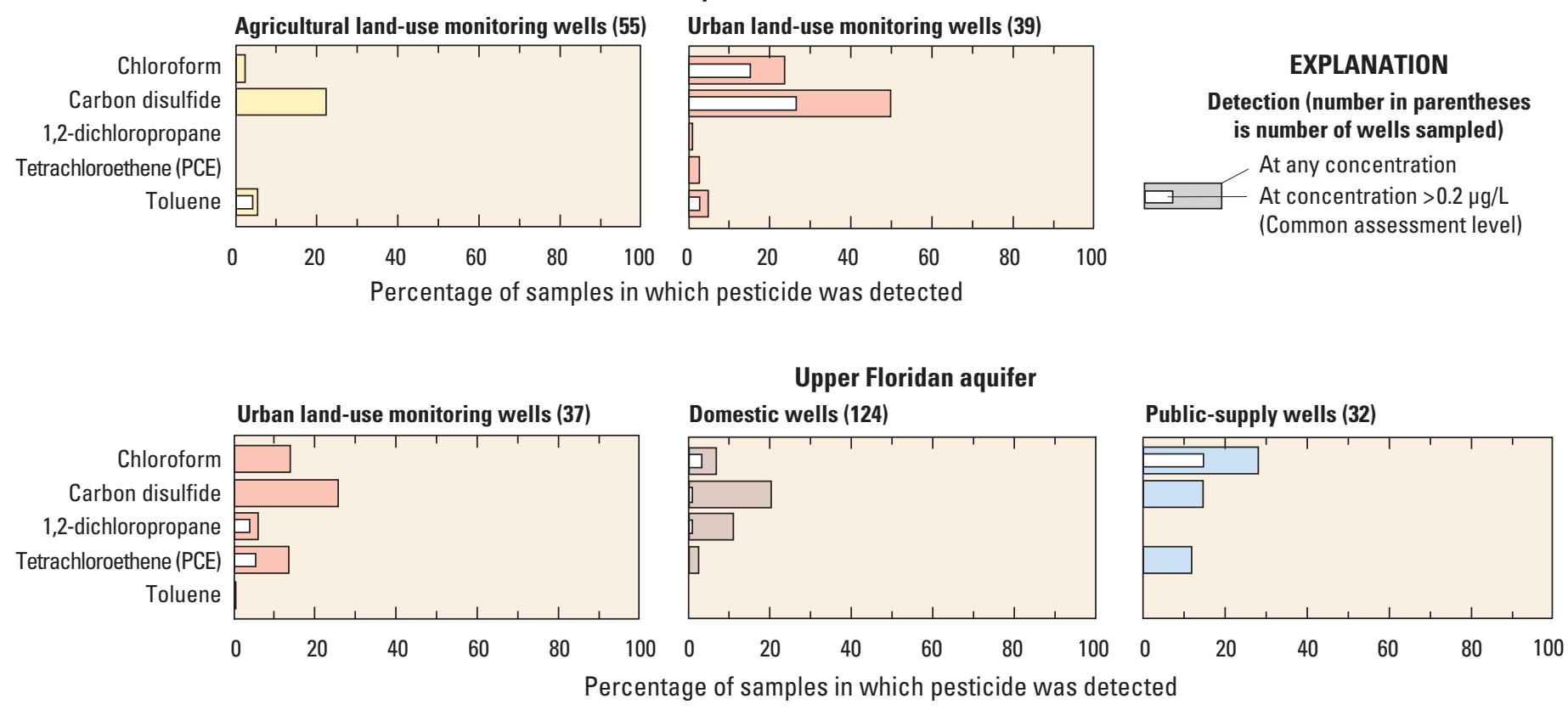

Figure 5-3. Chloroform and carbon disulfide were the VOCS most frequently detected in the surficial and Upper Floridan aquifers. Chloroform is a by-product of the chlorination of drinking water and its frequent occurrence may be related to infiltration of treated water and in some cases shock chlorination of domestic wells. Carbon disulfide is a solvent used in industrial applications. 


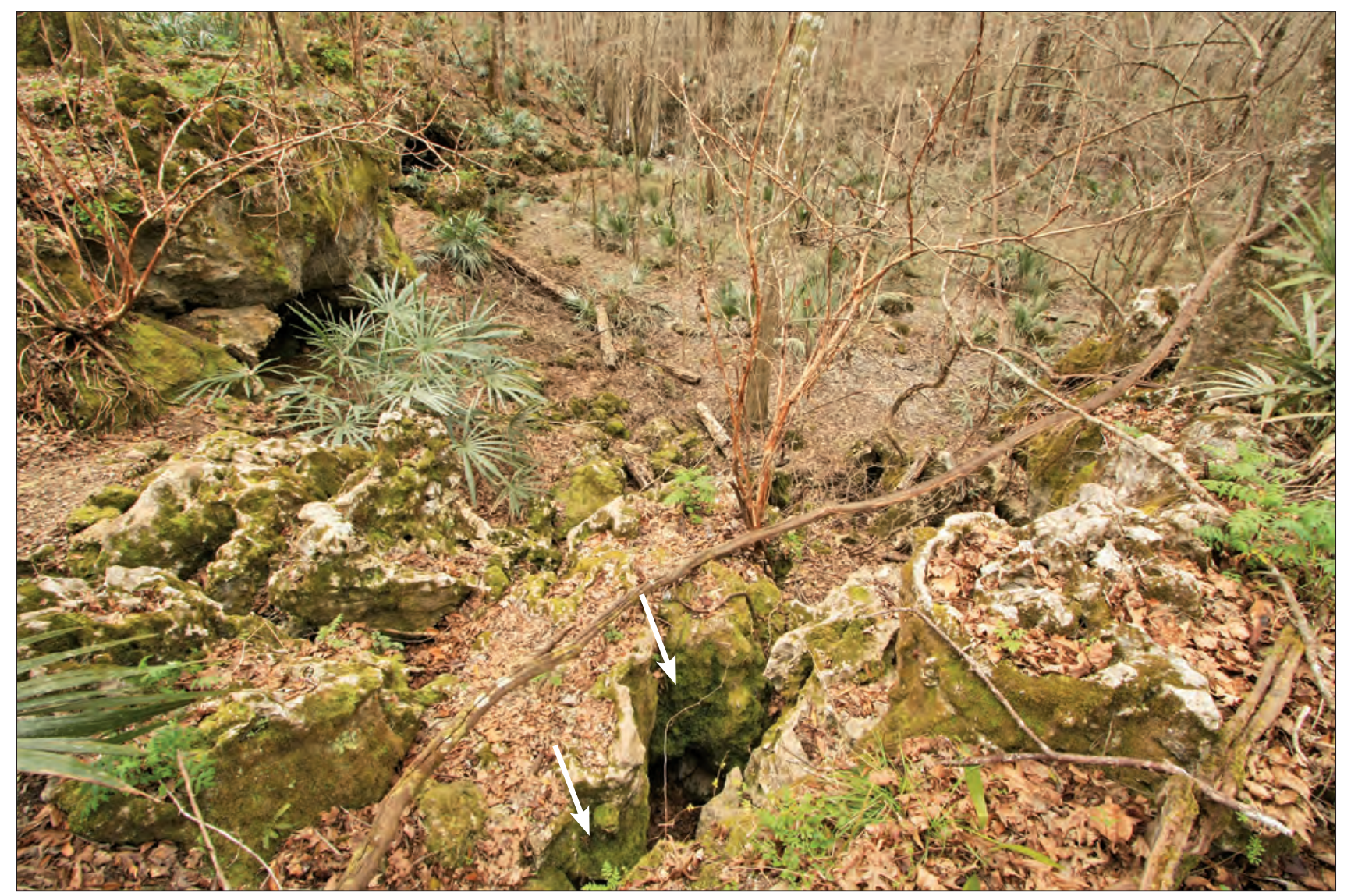

Dissolution along joints and fractures in the carbonate rocks that make up the Upper Floridan aquifer create pathways for water to move rapidly into and through the aquifer. 


\section{Chapter 6: Understanding Where and Why Key Contaminants Occur in Groundwater}

$\mathrm{F}$ lew contaminants were measured in groundwater in the Upper Floridan and surficial aquifers at concentrations approaching human-health benchmarks. Although contaminants related to human activities are detected commonly in the surficial aquifers, the presence of an extensive confining layer and the enormous quantities of water moving through the Upper Floridan aquifer keep concentrations of contaminants low in that aquifer in most areas. Human activities in some areas, however, have caused arsenic concentrations to increase. In other places, the presence of karst features makes the Upper Floridan aquifer vulnerable to contamination.
This chapter describes the sources of and factors that affect arsenic, radon, nitrate, and pesticide concentrations in the Upper Floridan aquifer and overlying surficial aquifers.

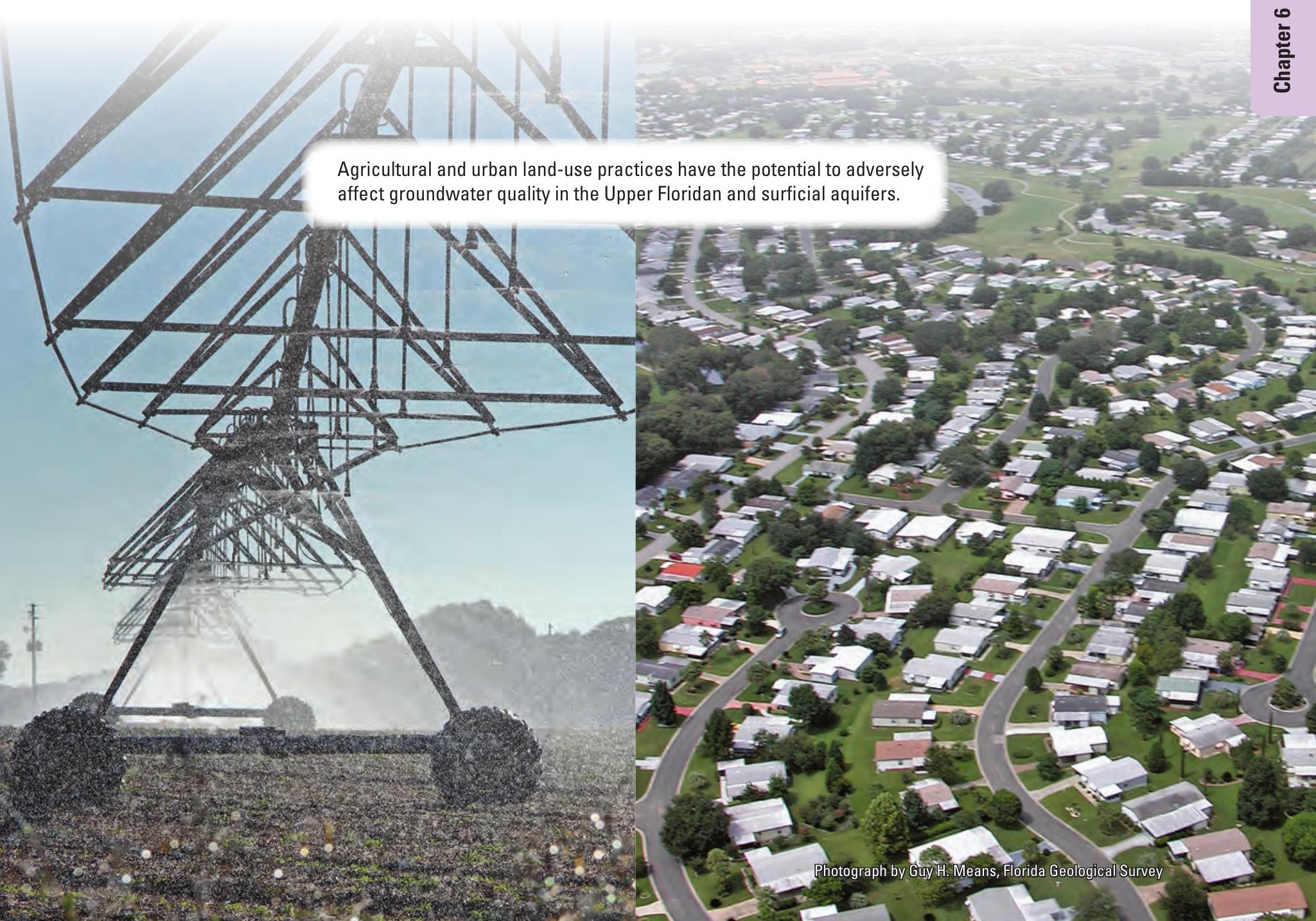




\section{Arsenic}

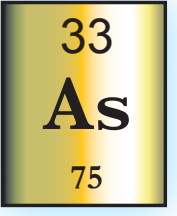

Arsenic is a trace element found in aquifer materials and can also come from pesticide application or industrial waste. Long-term exposure to arsenic in drinking water is related to elevated risks of cancer and skin damage.
Concentrations of arsenic were low-usually less than one-tenth of the MCL $(10 \mu \mathrm{g} / \mathrm{L})$ - in most wells in the surficial and Upper Floridan aquifers. Elevated concentrations in some wells in the Upper Floridan aquifer are related to high-volume pumping, injection of water during aquifer storage and recovery, or other human actions. These actions can change the native geochemistry of the groundwater, causing arsenic-rich minerals in the aquifer rocks to dissolve.

More than 80 percent of samples in both the surficial and Upper Floridan aquifers had low arsenic concentrations - less than $1 \mu \mathrm{g} / \mathrm{L}$ (fig. 6-1). Concentrations of arsenic in groundwater samples from the surficial and Upper Floridan aquifers are lower than those in many other aquifers sampled nationally (appendix 3). Arsenic concentrations exceeded the MCL of $10 \mu \mathrm{g} / \mathrm{L}$ in only one monitoring well and one public-supply well—both wells are in semiconfined parts of the Upper Floridan aquifer in the Tampa area. Elevated arsenic concentrations in groundwater used for drinking water are of concern because ingestion of arsenic is associated with cancers and other human-health problems. ${ }^{(26)}$ Some studies have reported a risk of developing lung and bladder cancers for people that consume drinking water with arsenic concentrations as low as $1 \mu \mathrm{g} / \mathrm{L} .(27)$
Arsenic concentrations in surficial aquifers

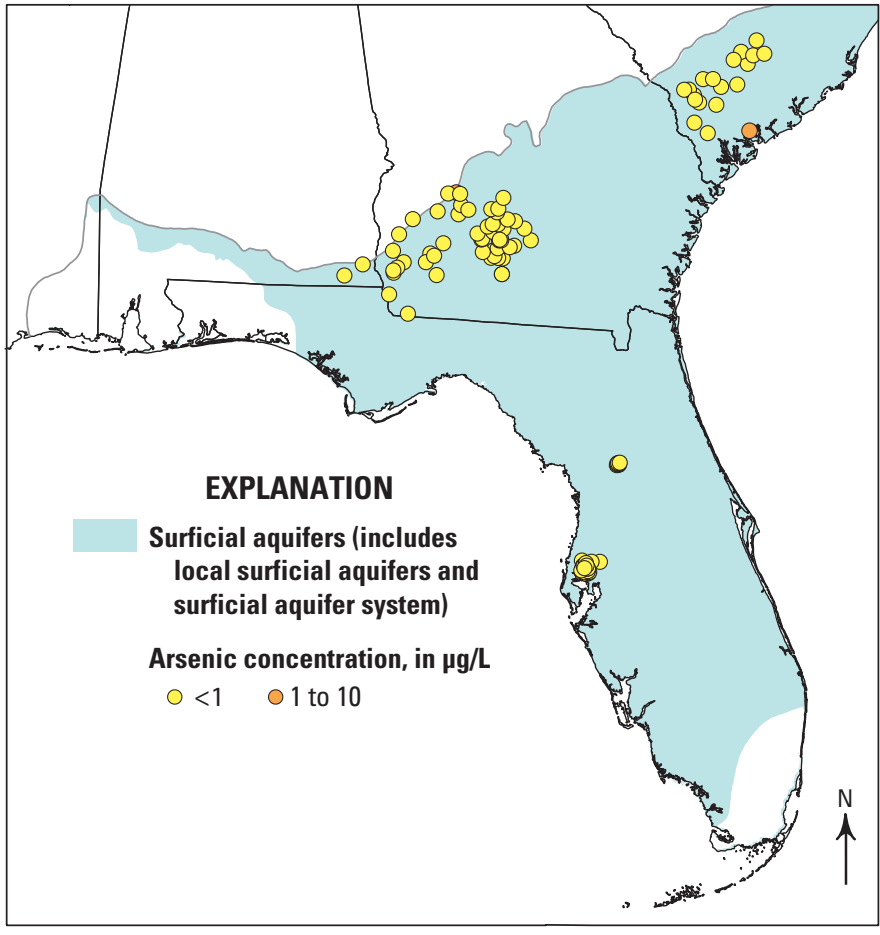

Arsenic concentrations in the Upper Floridan aquifer

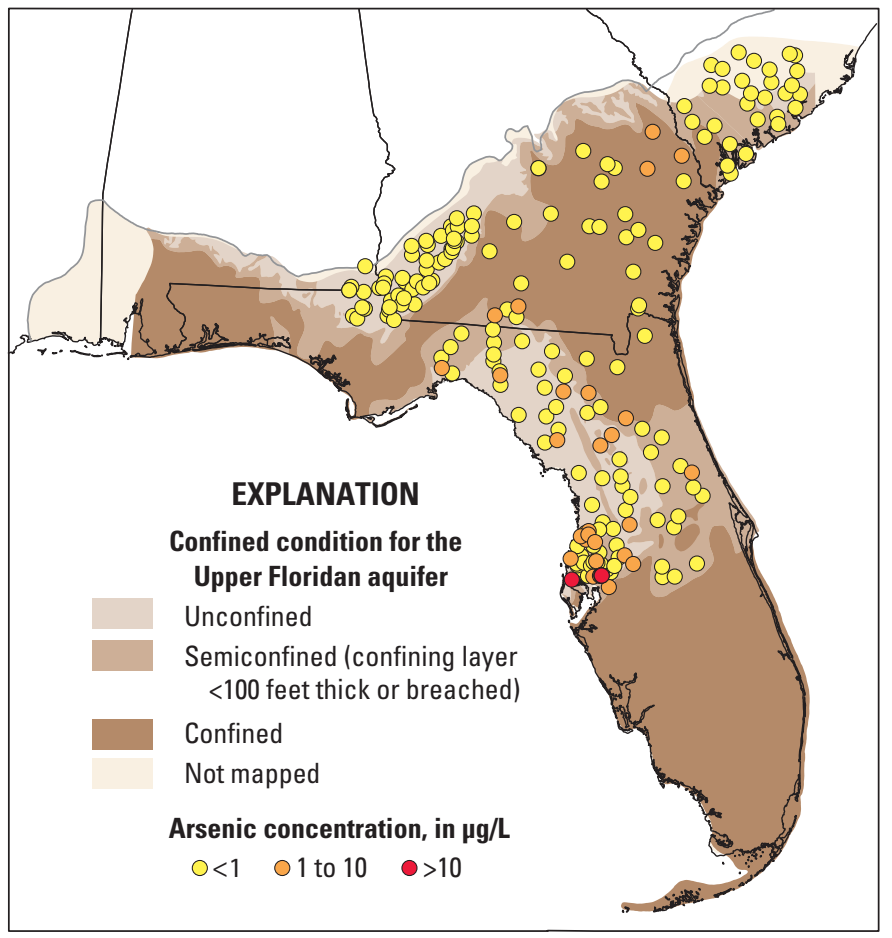

Figure 6-1. Elevated concentrations of arsenic $(>1 \mu \mathrm{g} / \mathrm{L})$ were more common in samples from the Upper Floridan aquifer than in samples from the surficial aquifers because trace minerals containing arsenic are present in the carbonate rocks that make up the Upper Floridan aquifer. High-volume pumping and other human activities that alter groundwater flow can cause arsenic-bearing minerals in the rocks of the Upper Floridan aquifer to dissolve and release arsenic into the groundwater. 


\section{Meeting the increasing demands for water can have unintended consequences}

High-volume pumping of public-supply wells in the Upper Floridan aquifer can cause arsenic concentrations in groundwater to increase (fig. 6-2). As pumping withdraws deep, anoxic groundwater from the Upper Floridan aquifer, oxic water in the overlying surficial aquifers moves downward and into the Upper Floridan aquifer and mixes with the native water. Mixing of oxic and anoxic groundwater also can be caused by a water-supply procedure called aquifer storage and recovery (see sidebar, Aquifer storage and recovery (ASR) can increase arsenic concentrations in the Upper Floridan aquifer, p. 40). The mixing of oxic and anoxic water causes some minerals that are stable under anoxic conditions to dissolve. One of those minerals, pyrite, is present in some of the limestones of the Upper Floridan aquifer and contains as much as 1 percent arsenic. ${ }^{(28)}$ When the pyrite dissolves, it releases arsenic into the groundwater.

Arsenic concentrations at a public-supply well near Tampa ranged from 4 to $19 \mu \mathrm{g} / \mathrm{L}$ at different depths sampled. This range in arsenic concentrations - from less than half to almost twice the MCL of $10 \mu \mathrm{g} / \mathrm{L}$-reflects the geochemical conditions associated with different depths and pumping conditions in the same well. The highest arsenic concentrations likely occurred as a result of oxic water from the overlying surficial aquifer moving down into a high-flow zone in the Upper Floridan aquifer, which can cause arsenic-rich pyrite to dissolve and release arsenic into the groundwater. ${ }^{(25)}$ Under normal operation, the public-supply well draws water from several flow zones in the aquifer, and arsenic concentrations are about $3 \mu \mathrm{g} / \mathrm{L}$ - well below the MCL.

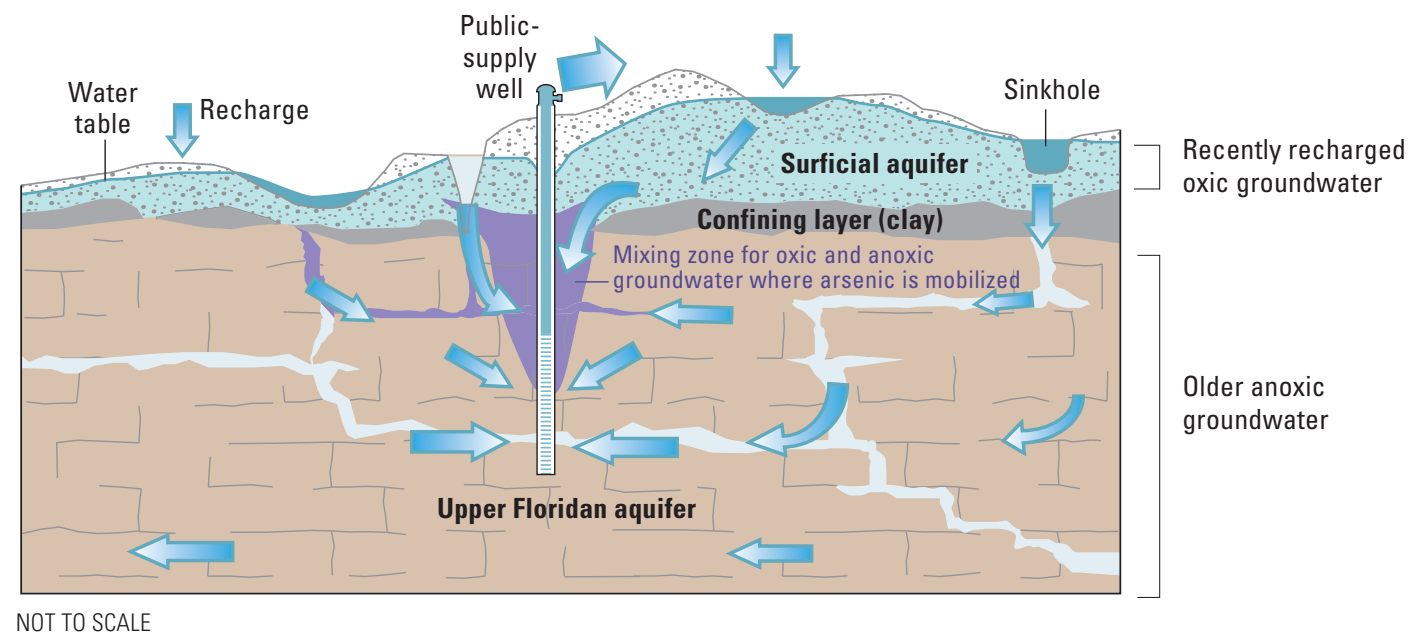

Figure 6-2. High-volume pumping for public supply can induce mixing of oxic water from surficial aquifers and anoxic groundwater from the Upper Floridan aquifer. The mixing, in turn, causes arsenic-rich minerals to dissolve and release arsenic to the groundwater near the public-supply well. 


\section{Aquifer storage and recovery (ASR) can increase arsenic concentrations in the Upper Floridan aquifer}

During ASR, the aquifer essentially functions as a "water bank" - water is injected into an aquifer during wet periods and is recovered during dry periods. The number of ASR facilities in Florida has increased greatly in the past $15-20$ years. ${ }^{(29)}$ By 2011, there were 26 ASR facilities in operation in Florida and more than 15 sites under development. ${ }^{(30)}$ Most of these facilities are located in coastal areas in southern Florida, where excess freshwater is stored in brackish parts of the Floridan aquifer system. In response to the projected increase in population and water demand over the next several decades in Florida, local and county water utilities in southern Florida are planning additional ASR facilities.

Limestone in southwest Florida contains arsenic-rich "framboidal" pyrite, so-called because of its raspberry shape ("framboise" is the French word for raspberry). Pyrite is stable where groundwater in the Upper Floridan aquifer is anoxic, but dissolves in the oxic water injected into the aquifer during the waterstorage phase of ASR. Arsenic has been measured in samples of recovered water at concentrations 5 to 10 times greater than the MCL of $10 \mu \mathrm{g} / \mathrm{L} .{ }^{(31)}$ The mobilization of arsenic during ASR could result in additional treatment costs to remove arsenic from the recovered water. Concentrations of arsenic decrease over time as additional cycles of storage and recovery deplete the arsenic in the aquifer materials. ${ }^{(31)}$

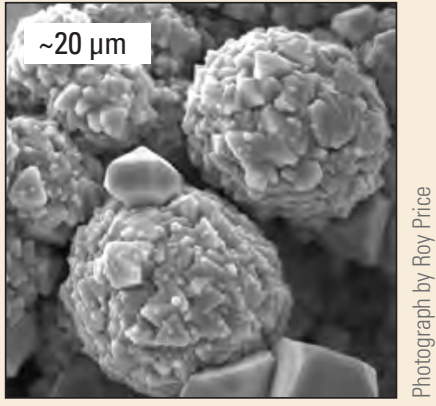

This image from a scanning electron microscope shows raspberry-shaped pyrite in the Upper Floridan aquifer. Some of the pyrite contains arsenic at concentrations greater than $1,000 \mathrm{mg} / \mathrm{kg}$. The arsenic can be released into groundwater when oxygen-rich water is injected into the aquifer during the ASR process.

\section{Schematic of an aquifer storage and recovery well}

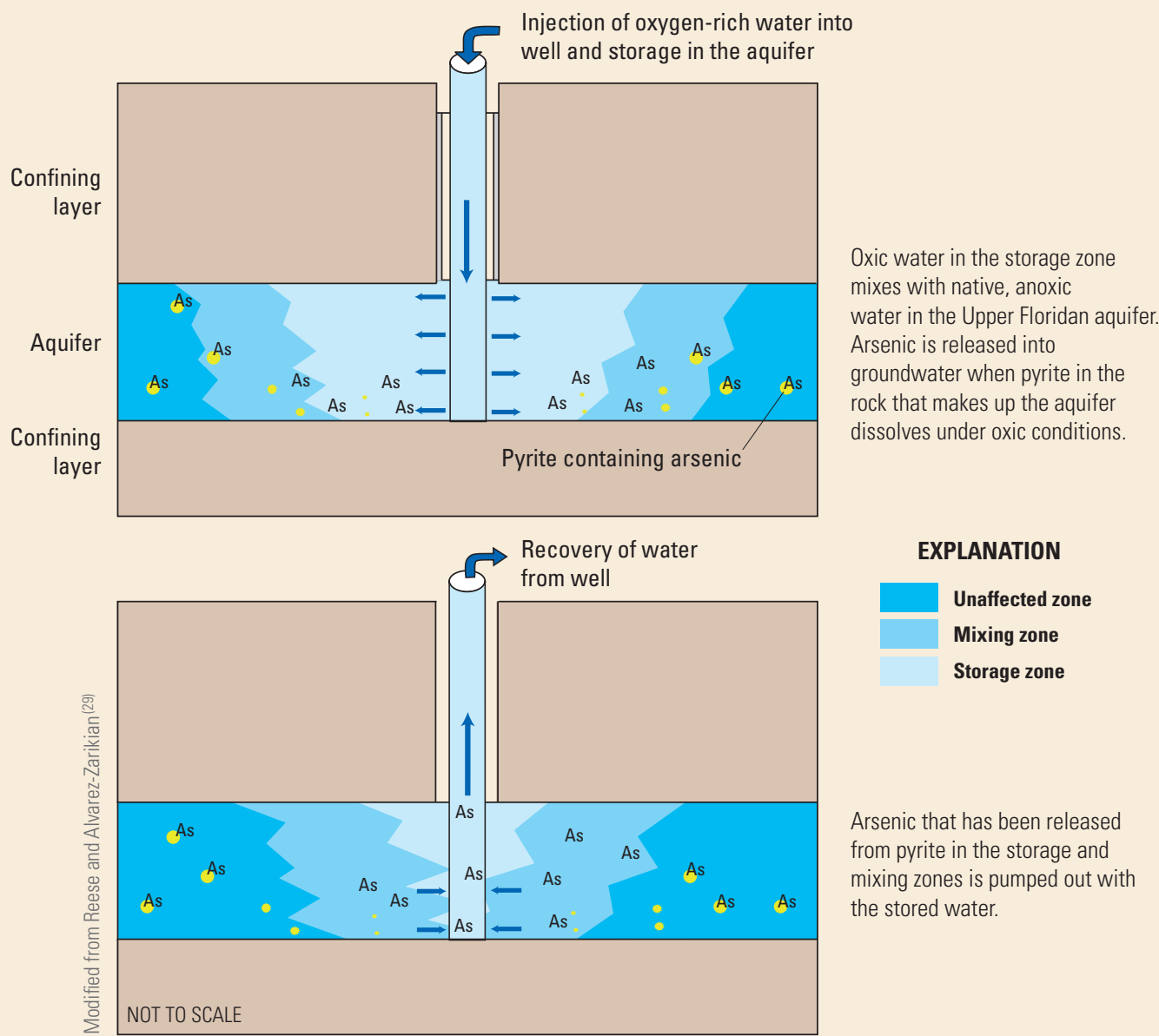




\section{Radon}

Radon, a by-product of the radioactive decay of uranium, was detected in nearly all samples from drinking-water wells (85 percent) - concentrations exceeded the proposed MCL of $300 \mathrm{pCi} / \mathrm{L}$ in about half of the samples, but rarely exceeded the alternative $M C L$ of $4,000 \mathrm{pCi} / \mathrm{L}$.

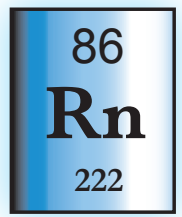

Radon is a colorless, odorless, tasteless gas that emits ionizing radiation-it occurs naturally in some rocks, soil, water, and air. Radon that is present in groundwater as a dissolved gas is derived from trace amounts of uranium in minerals in the rocks that make up the aquifer. Inhalation of excessive amounts of radon can cause lung cancer. Radon primarily enters homes from the soil and underlying rocks through cracks or openings in walls or basement floors, but also can enter homes as it degases from water. Residents that rely on surface water or public groundwater supplies are less likely to be exposed to radon than are residents with domestic wells - the large public-supply water distribution systems provide a greater amount of time for radon to degas or to decay (radon has a half-life of 3.8 days) before the water reaches a residence than do smaller domestic systems.

A little more than half (56 percent) of the samples from drinking-water wells in the Upper Floridan aquifer - most of which were domestic wells - contained radon at a concentration that exceeded the proposed MCL of $300 \mathrm{pCi} / \mathrm{L}$, but concentrations in only 3 percent of samples exceeded the alternative MCL of 4,000 pCi/L (see sidebar, Radon risk from water, below). Routine testing of water from domestic wells is not required, and homeowners are responsible for identifying and treating any water-quality problems. The occurrence of radon at elevated concentrations in domestic wells emphasizes the need for public education to describe where radon is likely to occur and what testing and treatment options are available.

\section{Radon risk from water}

Radon is a naturally occurring radioactive gas that is part of the decay series of uranium, an element that occurs in trace amounts in aquifer sediment and rocks. Radon is soluble in water and was detected in groundwater from nearly all of the wells sampled in the Upper Floridan aquifer. The USEPA classifies radon as a human carcinogen, ${ }^{(32)}$ and people who are exposed to radon, mostly in the air but also through drinking water, have an increased risk of getting cancer over their lifetime, especially lung cancer. ${ }^{(33)}$ Health effects from radon in drinking water are primarily through inhalation, after the gas is released from solution-for example, in the shower.

In 1999, the USEPA proposed two regulatory levels for radon in drinking water. The higher level of $4,000 \mathrm{pCi} / \mathrm{L}$, known as the alternative $\mathrm{MCL}$, would apply to public water systems or States that have programs to reduce radon risks from all sources. The lower level of $300 \mathrm{pCi} / \mathrm{L}$ would apply to systems or States that do not have such programs in place. ${ }^{(23)}$ Both proposed MCLs are used as human-health benchmarks in this circular, but are not yet formal regulatory benchmarks. For more information on radon and how to test for it, see http://www.epa.gov/radon/index.html. For State-specific information about radon in Florida, see http://www.doh. state.fl.us/environment/community/radon/index.html; in Georgia, see http://www.dca.ga.gov/development/ EnvironmentalManagement/programs/radon.asp; and in South Carolina, see http://www.scdhec.gov/environment/ envserv/radon.htm.

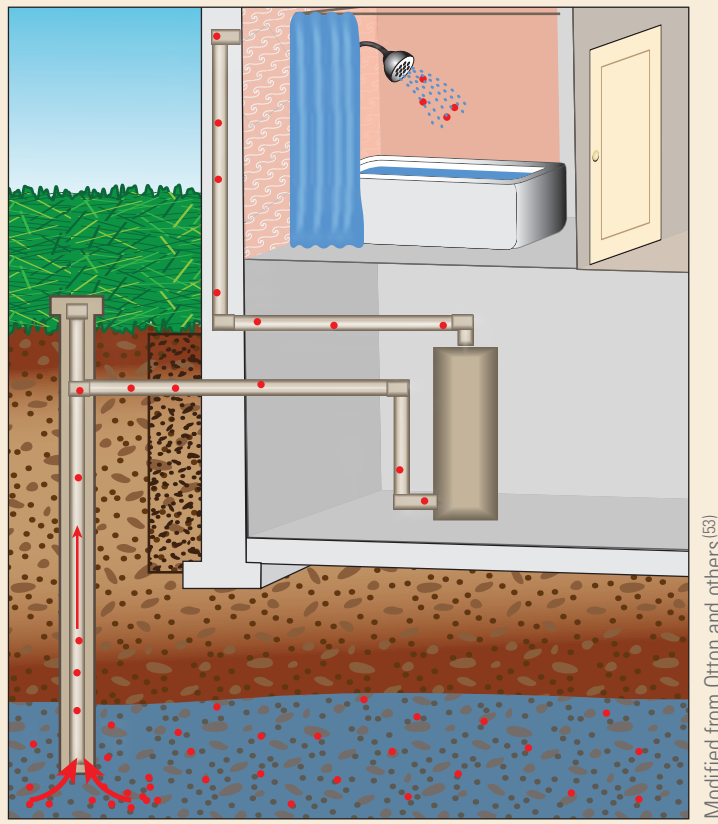

Radon gas (represented by red dots) dissolved in groundwater can be pumped from a domestic well through household pipes. Once the water is aerated through a faucet and released into the air, the radon can be inhaled when people are near showerheads or are drinking directly from faucets.
Radon is an element that results from the radioactive decay of uranium in aquifer materials. Radon in drinking water is associated with lung cancer and stomach cancer. 
Concentrations of radon commonly exceeded the lower, proposed MCL but rarely exceeded the higher, alternative $M C L$

Radon concentrations that exceeded the proposed MCL of $300 \mathrm{pCi} / \mathrm{L}$ were more common in samples from drinking-water wells in north-central Florida than in southern Georgia and southern South Carolina (fig. 6-3). These differences are related to spatial differences in uranium content in the rocks of the Upper Floridan aquifer. Radon concentrations in the central part of Florida were higher in samples from the surficial aquifers than from the Upper Floridan aquifer (fig. 6-4), but transport of radon from the surficial aquifers to the Upper Floridan aquifer is unlikely because of the short half-life of radon. Radon concentrations in samples from both the surficial and Upper Floridan aquifers were lower than in most of the other Principal Aquifers across the Nation where radon was measured (appendix 3).

Figure 6-3. About 80 percent of wells sampled in north-central Florida exceeded the proposed MCL of 300 pCi/L. Only 3 percent of drinking-water wells sampled exceeded the alternative MCL of $4,000 \mathrm{pCi} / \mathrm{L}$.

\section{EXPLANATION}

Radon concentration, in picocuries per liter

$<300$
300 to 4,000
$>4,000$

Radon concentration in drinking-water wells in the Upper Floridan aquifer

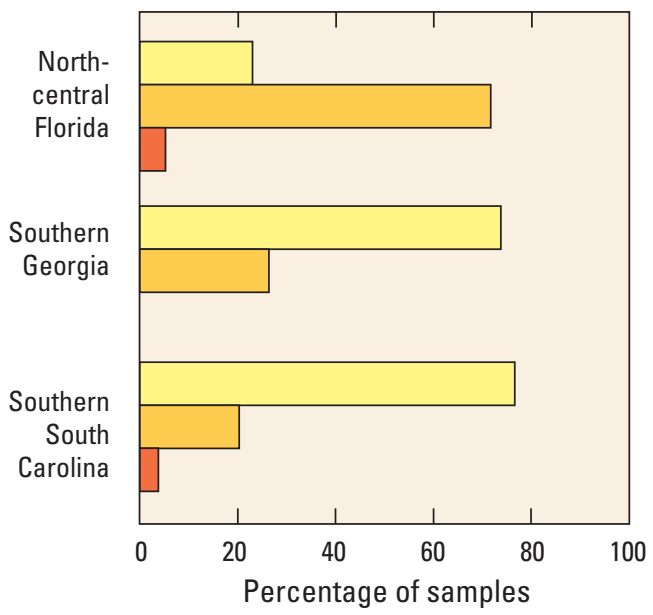

Radon concentrations in surficial aquifers

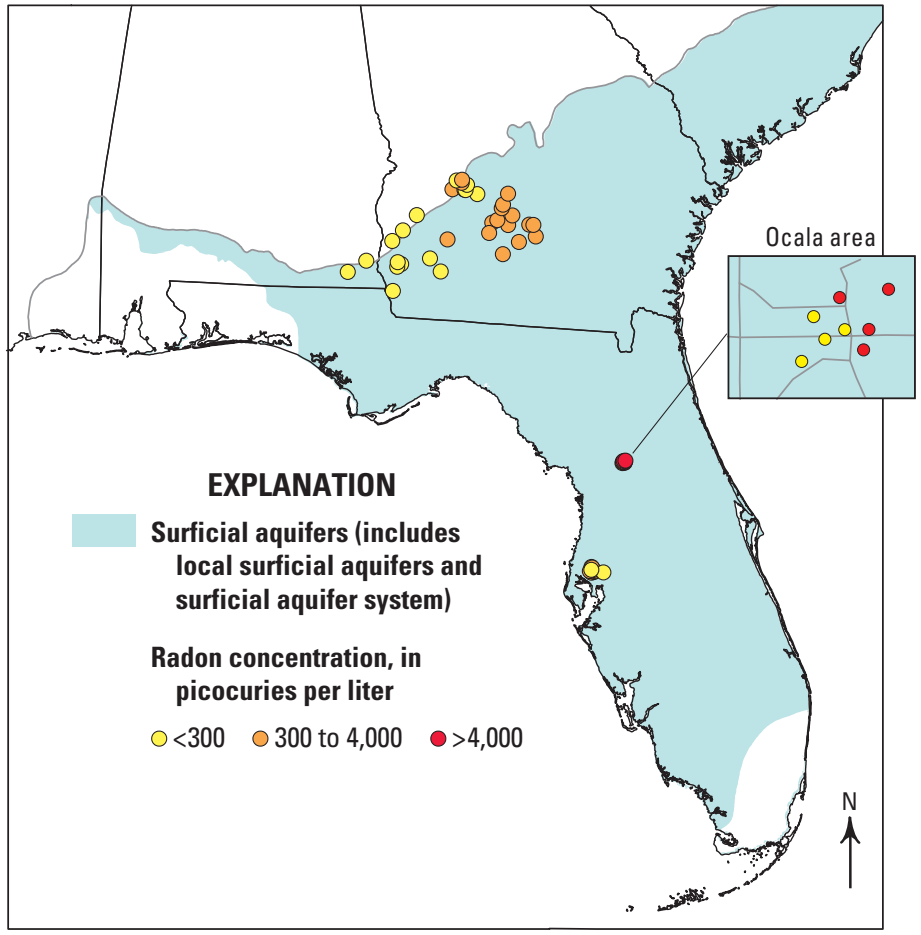

Radon concentrations in the Upper Floridan aquifer

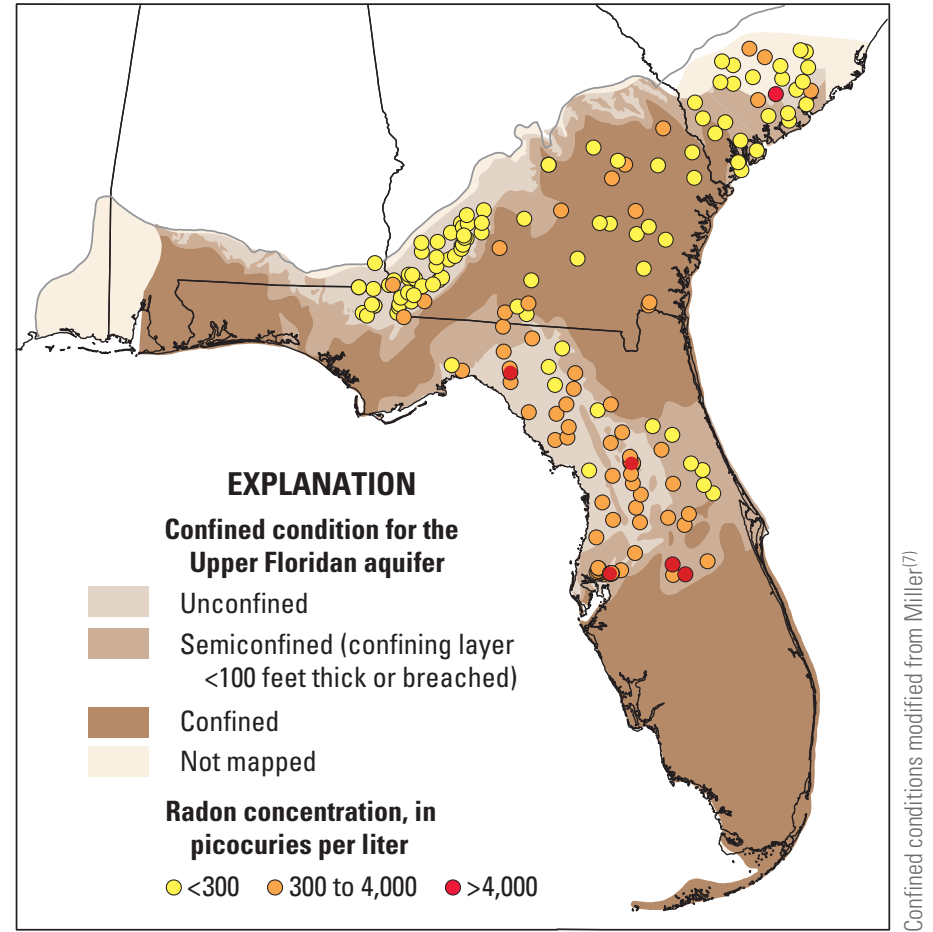

Figure 6-4. Some samples from the surficial aquifers in north-central Florida (0cala area) had relatively high concentrations of radon, but samples for analysis of radon primarily were collected in Georgia. Samples from the Upper Floridan aquifer were more widely distributed, and radon concentrations were highest in north-central Florida. Differences in the trace amounts of uranium in minerals in the rocks that make up the aquifer account for the differences in radon concentrations in groundwater. 


\section{Nitrate}

Nitrate concentrations in shallow monitoring wells in the surficial aquifers exceeded the MCL of $10 \mathrm{mg} / L$ as $N$ in about 1 of every 6 wells sampled, but nitrate concentrations in the Upper Floridan aquifer exceeded the MCL in only 1 of 249 wells sampled. Nitrate from manure and fertilizers applied in agricultural and urban areas can leach into the surficial aquifers, which in turn provide recharge to the Upper Floridan aquifer. Although nitrate concentrations in the Upper Floridan aquifer are not a drinking-water concern, more than half of the samples had concentrations greater than the nutrient criterion of $0.35 \mathrm{mg} / \mathrm{L}$ as $N$ for springs in Florida. For these crystal-clear springs, even small increases in nitrate concentrations can cause algal growth that degrades water quality.

\section{Nitrate concentrations are elevated in the surficial aquifers}

The application of fertilizer and animal manure in agricultural areas, such as those in southwestern Georgia and southern South Carolina, has contributed to elevated levels of nitrate in the surficial aquifers (fig. 6-5). In these agricultural areas, nitrate concentrations exceeded the MCL of $10 \mathrm{mg} / \mathrm{L}$ as $\mathrm{N}$ in about 1 of every 6 samples from wells in the surficial aquifers. The median concentration of nitrate in these wells was $3.3 \mathrm{mg} / \mathrm{L}$ and the maximum concentration was $35 \mathrm{mg} / \mathrm{L}$. Nitrate concentrations were above the background concentration of about $0.1 \mathrm{mg} / \mathrm{L}^{(24,34,35)}$ in more than three-fourths of the wells.

Nitrate concentrations in shallow groundwater underlying the Ocala and Tampa areas were affected by the overlying land use. About one-third of the samples had concentrations above the background concentration of $0.1 \mathrm{mg} / \mathrm{L}$. However, fewer samples in these urban areas exceeded the MCL than in agricultural areas - only one sample had a concentration $(12 \mathrm{mg} / \mathrm{L})$ that exceeded the MCL.

Elevated concentrations of nitrate in the surficial aquifers primarily are a drinking-water concern for those who use domestic wells that tap the surficial aquifers. Routine testing of water from these wells is not required, and homeowners are responsible for identifying and treating any water-quality problems. For those who rely on the Upper Floridan aquifer for their drinking water, elevated concentrations of nitrate in the surficial aquifers are a potential concern because the surficial aquifers provide recharge to the Upper Floridan aquifer.
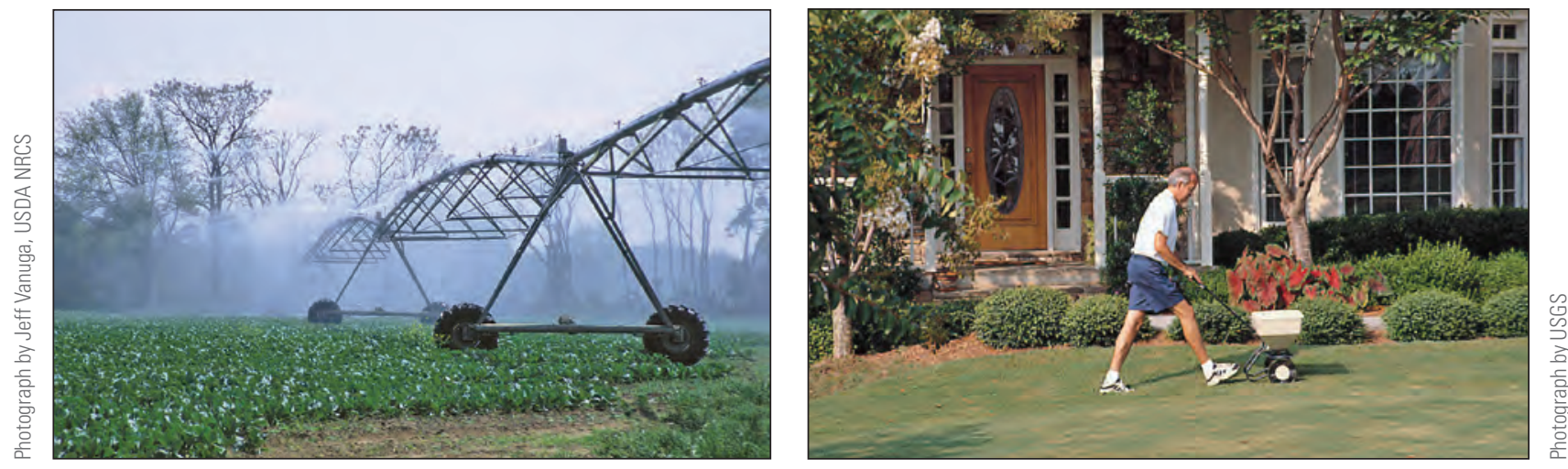

Nitrogen in fertilizers, which are applied to agricultural crops and urban landscapes alike, can leach into the surficial aquifers. 


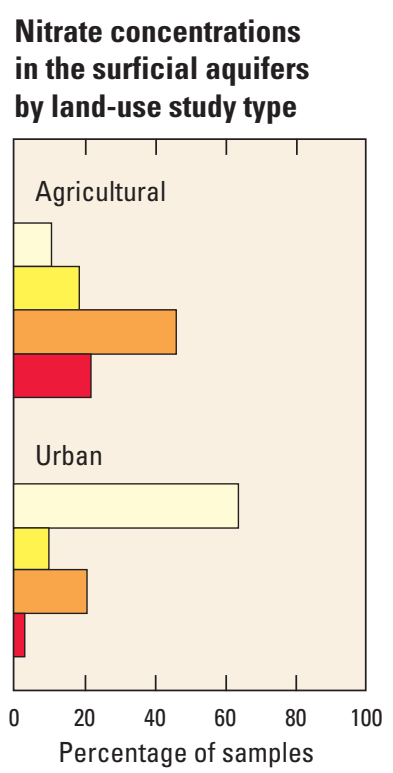

EXPLANATION

Nitrate concentration, in milligrams per liter as nitrogen

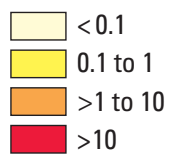

\section{Nitrate concentrations in surficial aquifers}

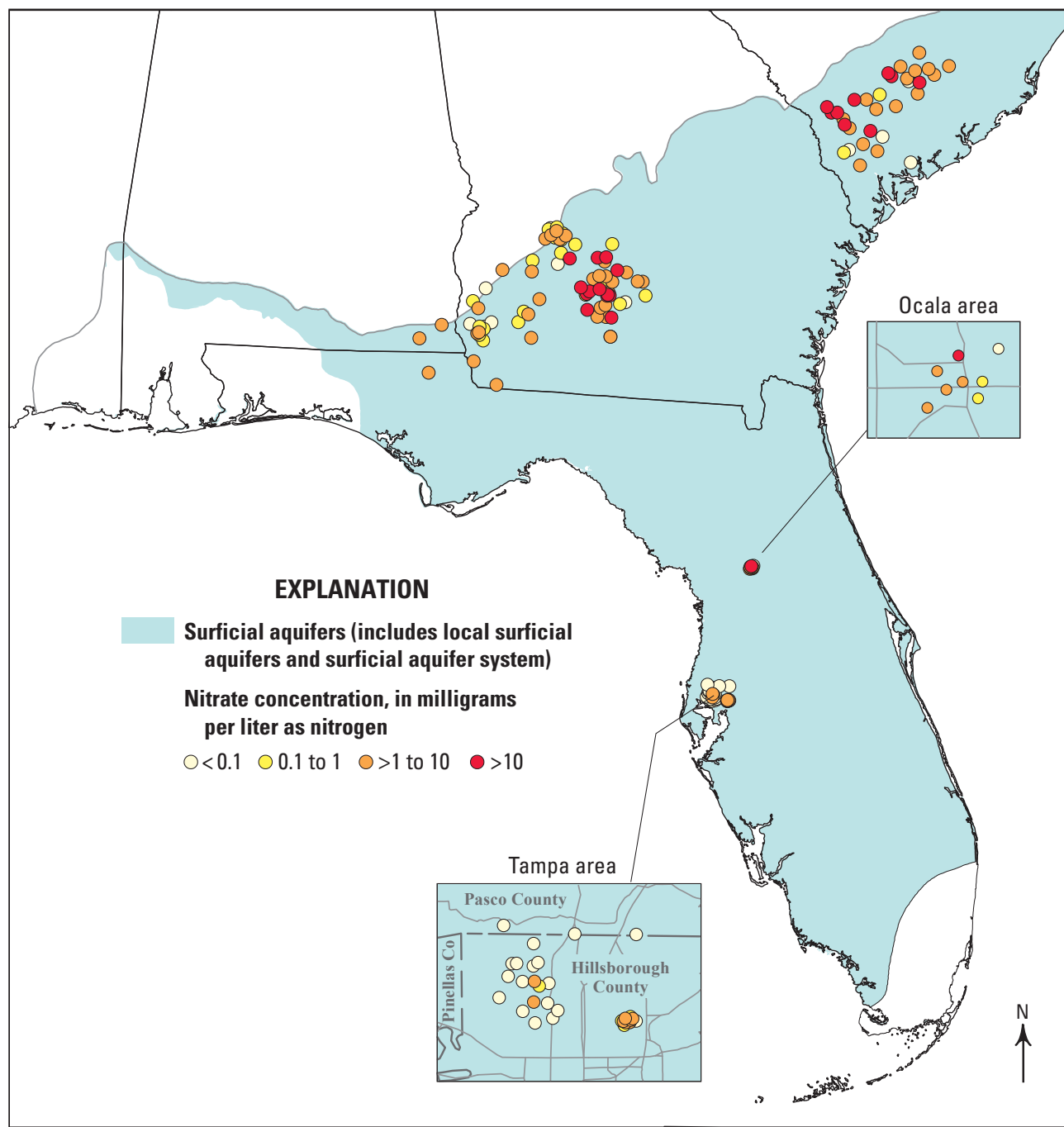

Figure 6-5. In urban and agricultural areas, fertilizer, wastewater, and livestock production are sources of nitrate to the surficial aquifers. Nitrate concentrations were greater than the drinking water MCL $(10 \mathrm{mg} / \mathrm{L})$ in about 20 percent of wells in agricultural areas and in about 3 percent of wells in urban areas.

\section{Nitrate concentrations in the Upper Floridan aquifer are controlled by land use and the presence or absence of a confining layer}

Despite four decades of large inputs of nitrogen from manure and fertilizer to agricultural and urban land that overlies the Upper Floridan aquifer, nitrate concentrations were near background levels of $0.1 \mathrm{mg} / \mathrm{L}$ in more than half of the wells sampled in the Upper Floridan aquifer. Nitrate concentrations in this aquifer were substantially lower than those in other Principal Aquifers across the Nation (appendix 3). Concentrations of nitrate in only one sample from the Upper Floridan aquifer-from an agricultural land-use monitoring well in southwestern Georgia - exceeded the MCL of $10 \mathrm{mg} / \mathrm{L}$ (fig. 6-6). Nitrate concentrations did not exceed the MCL in any of the drinking-water wells sampled. The effects of human activities were nonetheless evident: concentrations were greater than background levels of $0.1 \mathrm{mg} / \mathrm{L}$ in about one-fourth (24 percent) of the drinking-water wells.

Elevated nitrate concentrations in the Upper Floridan aquifer occurred mostly in southwestern Georgia and west-central Florida. Nitrate concentrations exceeded the background level of $0.1 \mathrm{mg} / \mathrm{L}$ in about 80 percent of the wells sampled in unconfined areas of the Upper Floridan aquifer and were greater than $1 \mathrm{mg} / \mathrm{L}$ in about 60 percent of these wells because land 
use is mostly agricultural, the Upper Floridan aquifer is predominantly unconfined, and the groundwater is oxic. In these areas, the aquifer is particularly vulnerable to contamination from nitrate. Agricultural activities, such as the application of fertilizers and manure and confined animal feeding operations, provide a source of nitrate. The lack of a confining layer allows nitrate from the land surface to move down into the aquifer. Sinkholes and other karst features, which are common where the Upper Floridan aquifer is unconfined, funnel surface runoff directly into the Upper Floridan aquifer (see sidebar, Karst, p. 20).

Nitrate concentrations in the Upper Floridan aquifer were lowest throughout much of southeastern Georgia, southeastern South Carolina, and northeastern Florida, where the Upper Floridan aquifer is confined by a thick clay layer (fig. 6-6). Nitrate concentrations exceeded the background level of $0.1 \mathrm{mg} / \mathrm{L}$ in only about 20 percent of the wells sampled in semiconfined and confined areas of the Upper Floridan aquifer and were greater than $1 \mathrm{mg} / \mathrm{L}$ in about 10 percent of these wells. The confining layer limits the downward movement of water, which contains nitrate and other contaminants, from the surficial aquifers to the Upper Floridan aquifer. Further, groundwater in these semiconfined and confined areas of the Upper Floridan aquifer commonly is anoxic, which facilitates the transformation of nitrate to nitrogen gas by denitrification.

\section{Nitrate concentrations in the Upper Floridan aquifer}

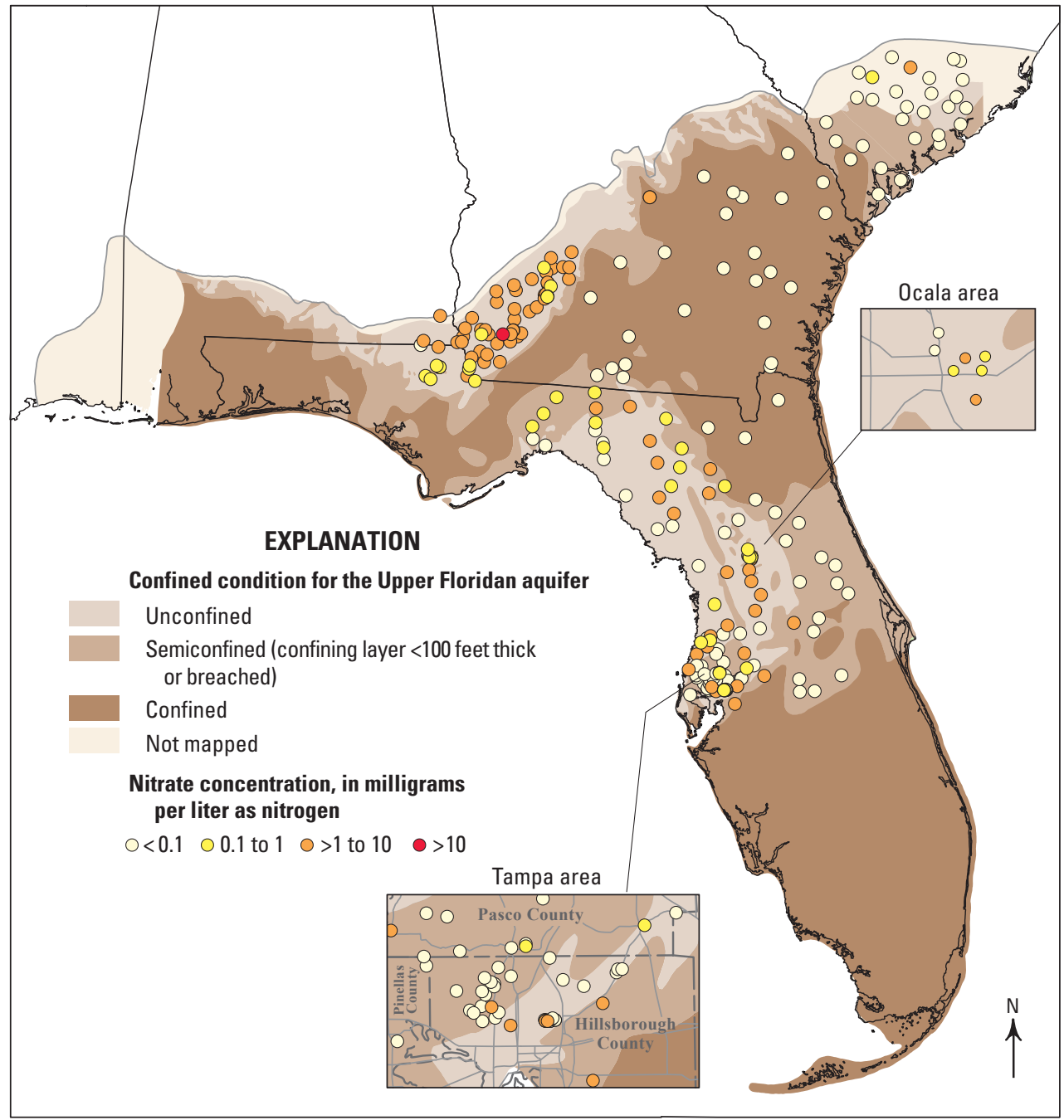

Figure 6-6. Hydrogeology - in particular the presence or absence of a confining layer-has a strong influence on concentrations of nitrate in the Upper Floridan aquifer. Where the Upper Floridan aquifer is unconfined, groundwater was predominantly oxic, and nitrate concentrations commonly were greater than $1 \mathrm{mg} / \mathrm{L}$. In the confined and semiconfined parts of the Upper Floridan aquifer, in contrast, groundwater was predominantly anoxic, and most nitrate concentrations were less than $0.1 \mathrm{mg} / \mathrm{L}$.
Distribution of nitrate concentration by confined condition in the Upper Floridan aquifer

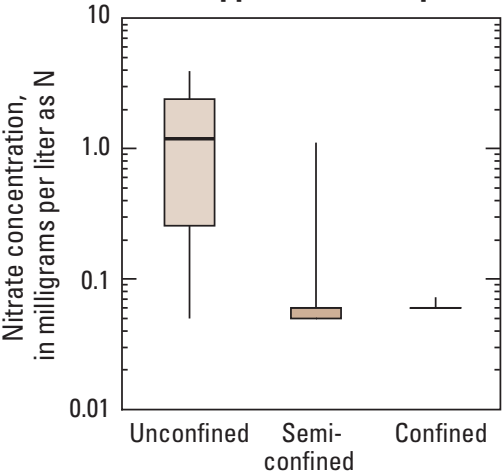

Confined conditions in the Upper Floridan aquifer
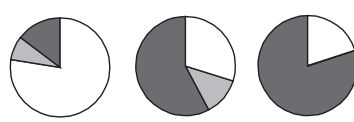

EXPLANATION

Redox condition

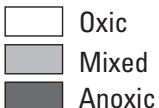

See sidebar, Boxplots, p. 46 


\section{Boxplots}

Boxplots are used to illustrate how results are distributed within a group. The "box" ranges from the 25th to the 75th percentile and represents 50 percent of the data. The horizontal line in the middle of the box is the median value-one-half of the values in the group are greater than the median and one-half are less.

Percentiles describe the percentage of values in a group that are less than the given value: 25 percent of the values in a group are less than the 25 th percentile; 75 percent of the values in a group are less than the 75 th percentile. The median is also the 50 th percentile.

If, for example, the 75th percentile for the measured concentration of a contaminant in a group of wells is equal to the human-health benchmark for that contaminant, then 75 percent, or three-fourths, of the wells have a concentration of that contaminant less than the benchmark, and 25 percent, or one-fourth, have a concentration greater than the benchmark.

The "whiskers" (vertical lines) in these figures extend to the 10th and 90th percentiles; box and whiskers together represent 80 percent of the data.
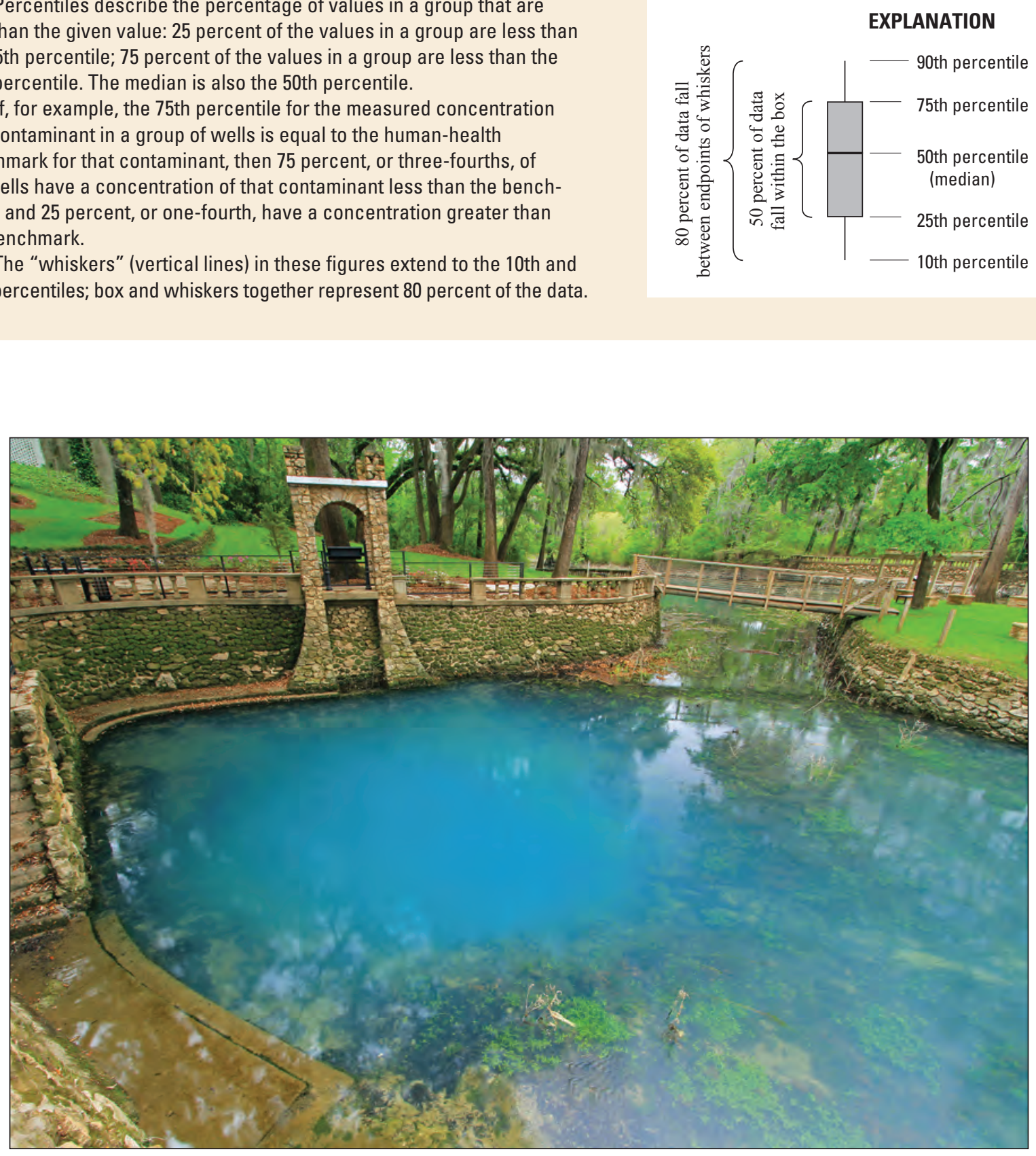

Radium Springs, Dougherty County, Georgia. 


\section{Nitrate concentrations in groundwater often exceed the criterion for springs in Florida}

Groundwater from the surficial and Upper Floridan aquifers discharges as spring flowas base flow to rivers and streams, and as freshwater to estuaries - commonly in the form of "crystal-clear" water that supports a variety of aquatic plants and animals throughout the State of Florida. In addition, many large springs are recreational sites that contribute substantially to the economies of the surrounding areas. Human activities over the past several decades have degraded groundwater quality, and many spring runs, streams, and rivers in Florida have suffered from an increase in nuisance aquatic vegetation, reduced clarity, and algal blooms. The algal blooms, which can produce toxins that are harmful to humans, animals, and ecosystems, result from elevated concentrations of nutrients (nitrogen and phosphorus) that originate from fertilizers, wastewater discharge, urban stormwater runoff, and other human sources.

In response to water-quality degradation from nutrients, the USEPA approved the State of Florida's nutrient criteria in November 2012 for spring vents, lakes, streams, and south Florida estuaries. The criterion for nitrate and nitrite is an annual geometric mean of $0.35 \mathrm{mg} / \mathrm{L}$ for spring discharge. ${ }^{(36)}$

Nitrate concentrations measured in samples from the Upper Floridan aquifer commonly exceeded the nitrate criteria for springs - nearly half of the samples had concentrations greater than $0.35 \mathrm{mg} / \mathrm{L}$. Despite large inputs of nitrogen in agricultural and urban areas, nitrate concentrations in groundwater remain low compared to other Principal Aquifers across the Nation (appendix 3). Nevertheless, small increases in groundwater nitrate concentrations can have adverse effects on the water quality and aquatic species that rely on spring flows for habitat and can limit the use of springs for recreation.

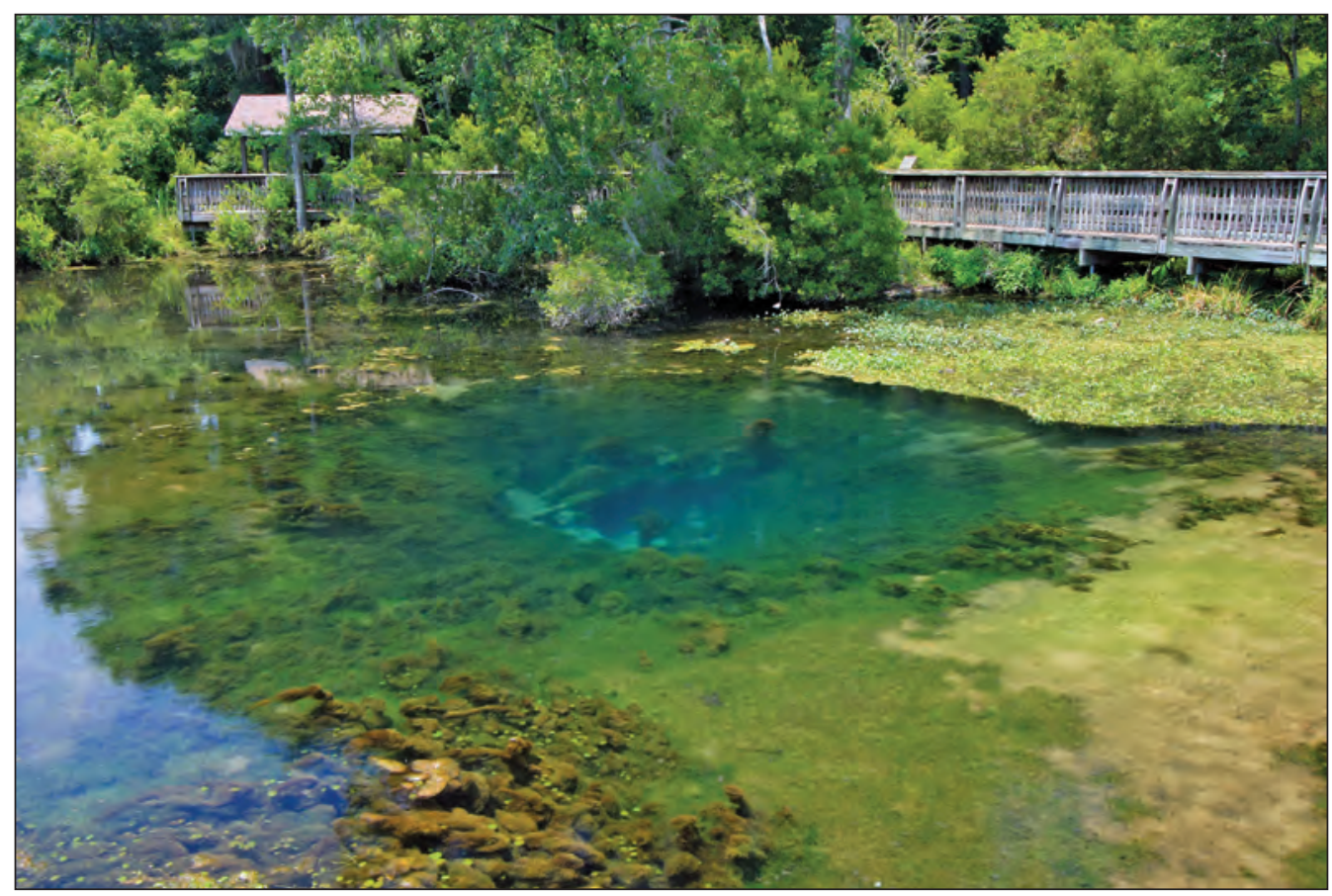

Nitrate and phosphorus in spring discharge can cause increases in the amounts of nuisance aquatic plants and algae in spring pools and runs. 


\section{Nitrate contamination of springs in Florida and Georgia}

The Upper Floridan aquifer in Florida and Georgia sustains one of the largest concentrations of freshwater springs in the world. More than 1,000 recorded artesian springs in Florida discharge more than 9 billion gallons per day from the Upper Floridan aquifer. ${ }^{(37)}$ The exceptionally clear spring flow is a unique recreational resource enjoyed by millions of people for generations. Sites such as Weeki Wachee Springs, Wakulla Springs, Ichetucknee Springs, Rainbow Springs, and Silver Springs continue to be popular vacation destinations. The springs also provide important base flow to rivers and streams and freshwater to estuaries. The springs offer habitat for diverse aquatic life, and the springs and karst support many native species, such as snails and crayfish, at least 30 of which are imperiled. (38)

Springs in northern Florida and southern Georgia serve as early warning systems for the degradation of regional groundwater quality. Over the past several decades, human activities have severely affected spring water quantity and quality and associated ecosystems. As a result of increased pumping and climatic influences, water levels in the Upper Floridan aquifer have dropped in many places, resulting in lower spring discharge. In some cases, springs have stopped flowing. ${ }^{(39)}$ In response to these changes occuring at springs and because of the importance of springs to the local economies, the Florida Legislature has provided over $\$ 15$ million in funding for the Florida Springs

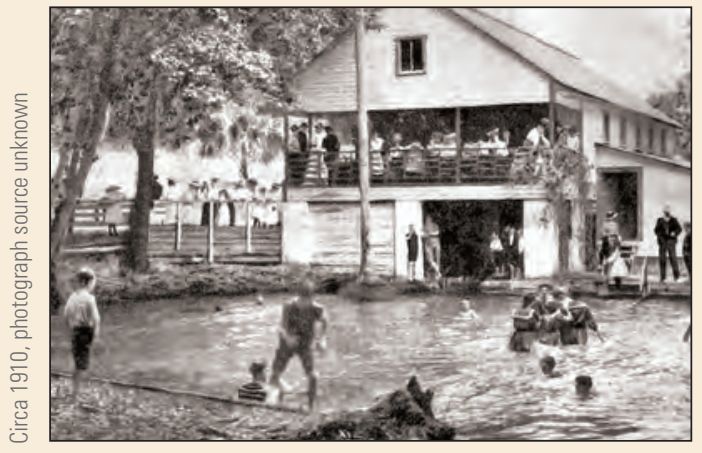

Wekiwa Springs.

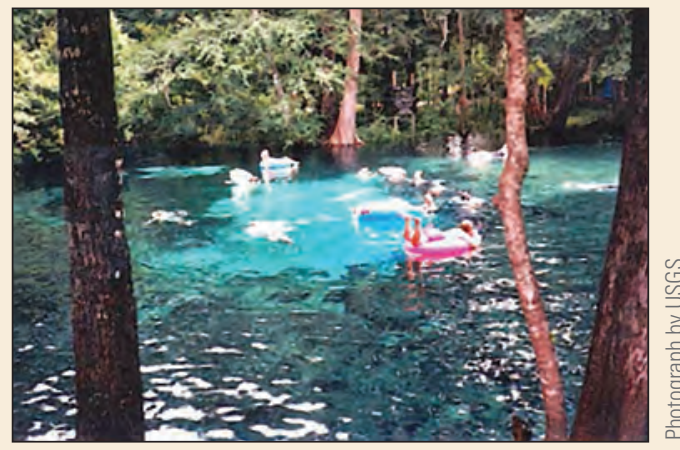

Ginnie Springs.

More than 1,000 springs have been mapped in the Upper Floridan aquifer in Florida and Georgia. Most of the springs are located in unconfined and semiconfined areas of the aquifer and provide water for recreation, base flow to rivers, and habitat for diverse animal species.

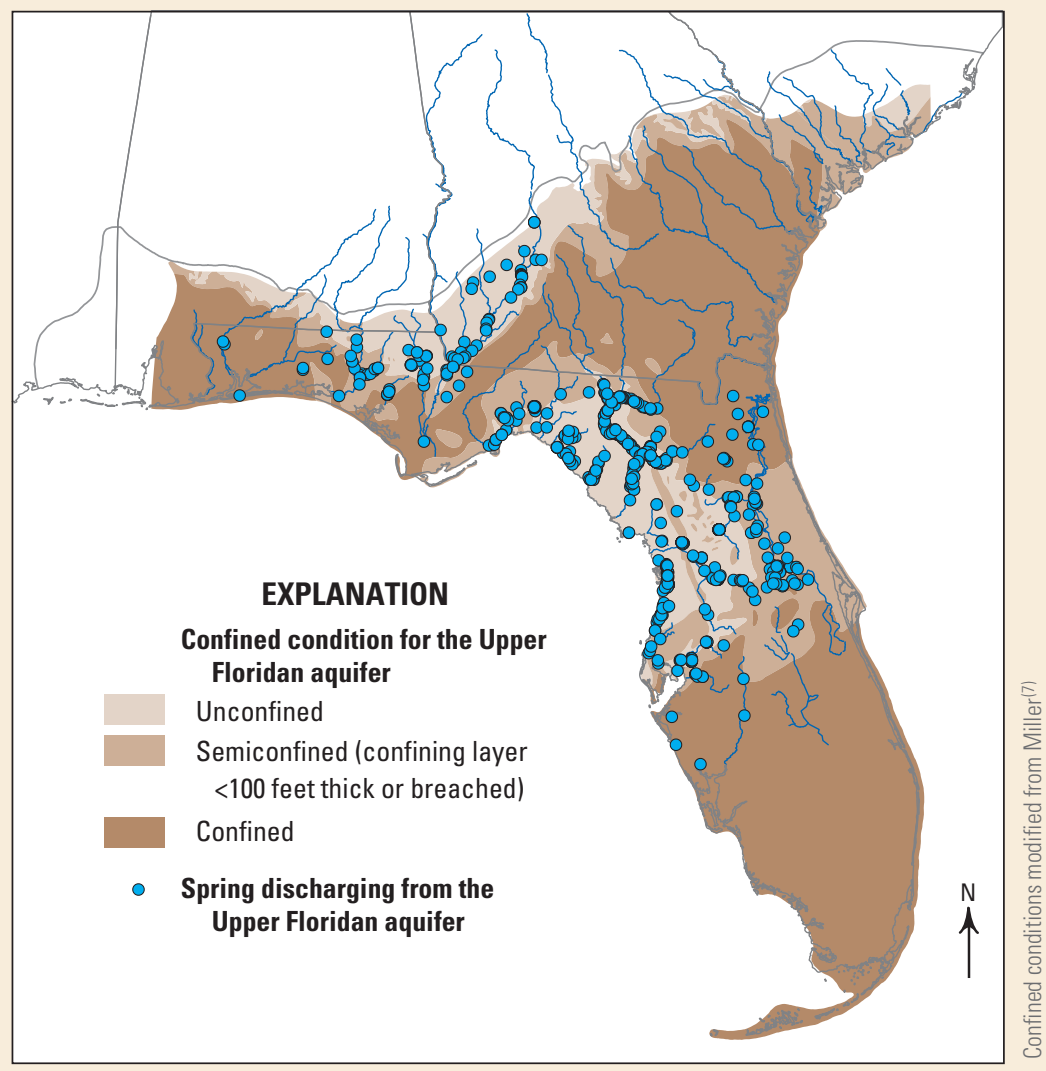


Initiative program, which began in 2001. The program focuses on education and outreach, protection and restoration, and research and monitoring of the State's freshwater springs.

Nitrate concentrations in spring flow have increased over the past several decades in many springs as a result of nitrogen inputs from fertilizers, septic tanks, and land application of treated municipal wastewater and biosolids. Springflow contributes large loads of nitrogen to surface waters ${ }^{(40-43)}$ and, as a result, nuisance levels of algae and macrophytes have increased in many spring-fed rivers in Florida. ${ }^{(39,44,45)}$ In the Suwannee River Basin in Florida, which contains the majority of first magnitude springs (springflow greater than 100 cubic feet per second) in Florida, fertilizers have been the dominant source of nitrogen since 1940. ${ }^{(46,47)}$ Fertilizer use peaked in the area in the 1970s, but spring water responses to changes in fertilizer use have been muted and delayed because it takes decades, on average, for water to move through the aquifer and discharge at springs. ${ }^{(48)}$

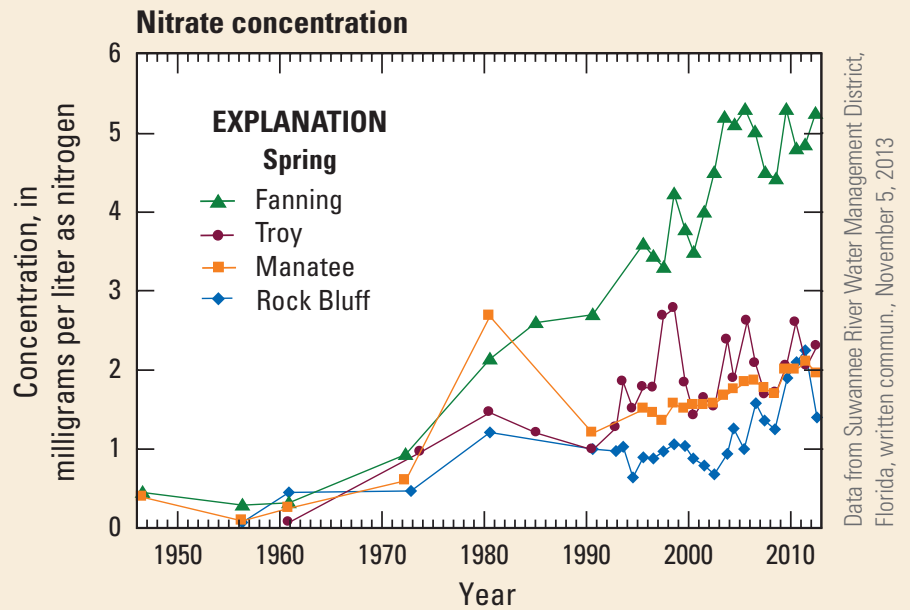

Left, Nitrate concentrations have increased from less than $0.5 \mathrm{mg} / \mathrm{L}$ in 1950 to greater than $1 \mathrm{mg} / \mathrm{L}$ in 2005 in spring flow from four springs in the Suwannee River Basin. These types of changes in nitrate concentrations likely contribute to the increase of algae growth in many springs in Florida. Below, The clarity of water in Fanning and Peacock Springs has decreased over the last 20 years, in part because of algae. These types of changes to springs in Florida can discourage tourism and demonstrate how sensitive these springs are to nutrient inputs.

\section{Fanning Springs}

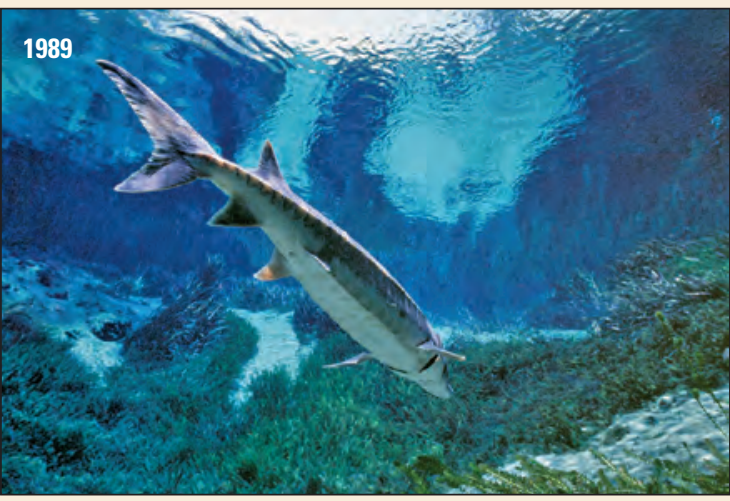

\section{2}

Peacock Springs
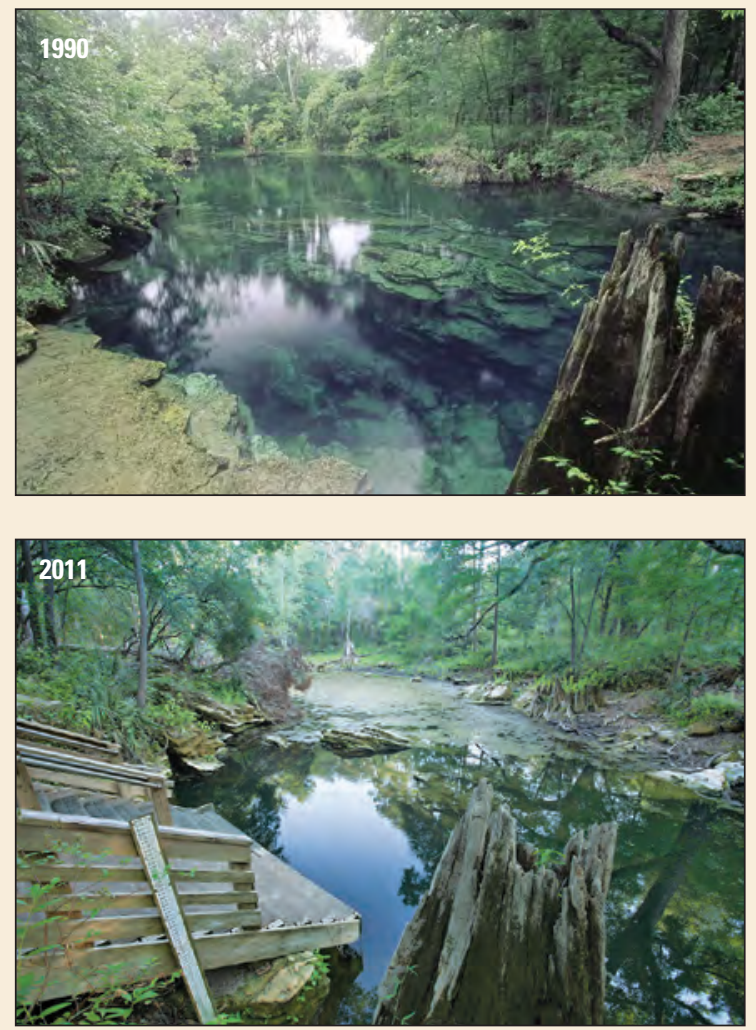


\section{Pumping of public-supply wells can increase vulnerability to nitrate contamination}

Prolonged, high-volume pumping for water supply can affect the quality of groundwater withdrawn from the Upper Floridan aquifer. Groundwater is the source of drinking water for nearly 1.6 million people in the Tampa area, where over $325 \mathrm{Mgal} / \mathrm{d}$ are pumped from the unconfined and semiconfined parts of the Upper Floridan aquifer for drinking water. ${ }^{(11)}$ In this area, the Upper Floridan aquifer is separated from the surficial aquifers by a confining layer. Groundwater from most of the wells in the Upper Floridan aquifer was older and had much lower nitrate concentrations than did groundwater in the overlying surficial aquifers (fig. 6-7). Unexpectedly, the groundwater age and nitrate concentration in a Tampa public-supply well drilled into the Upper Floridan aquifer were more similar to the age and concentrations in samples from monitoring wells that tap the surficial aquifers than to the age and concentrations in monitoring wells that tap the Upper Floridan aquifer. This finding indicates that pumping might be causing nitrate-rich water from the surficial aquifers to move down along conduits into the parts of the Upper Floridan aquifer tapped by the public-supply well.

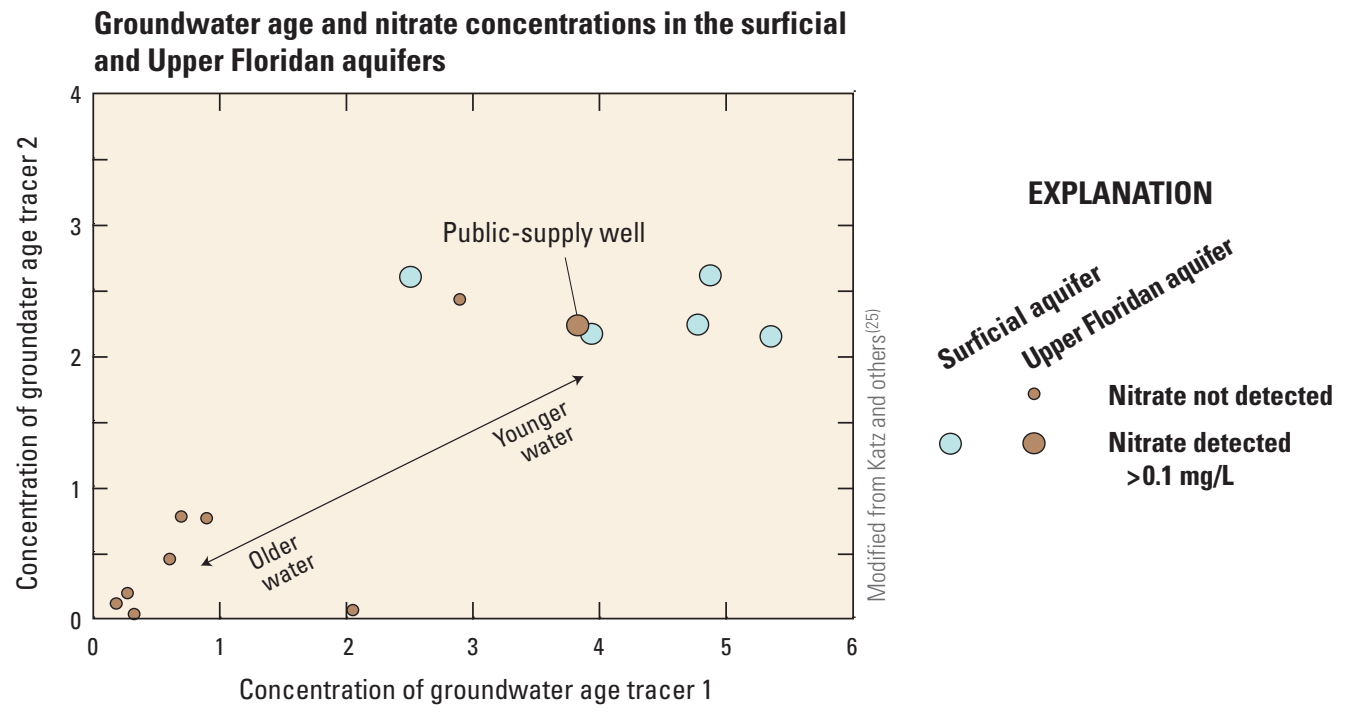

Figure 6-7. In Tampa, Florida, the similarity between groundwater age and nitrate concentrations in samples from a public-supply well that taps the Upper Floridan aquifer and from the surficial aquifers indicates that highvolume pumping of the public-supply well is causing nitrate-rich groundwater to move downward from the overlying surficial aquifer into the Upper Floridan aquifer-parts of the Upper Floridan aquifer not affected by pumping had older groundwater and lower nitrate concentrations. 


\section{It may take decades for nitrate concentrations in groundwater to respond to changes in nitrogen inputs}

How will nitrate concentrations in groundwater change in the future if nitrogen inputs stay the same, gradually decrease, or cease entirely? These questions were addressed using groundwater-flow models used to simulate nitrate concentrations on the basis of changes in the amount of nitrogen inputs. ${ }^{(49)}$ Three scenarios were investigated: (1) nitrogen inputs remain at the amounts applied in 2001 (the most recent year for which estimates of nitrogen input were available); (2) a gradual reduction (4 percent per year) in nitrogen inputs from 2002 to 2050; and (3) no nitrogen inputs after 2001. Three management scenarios were compared for water from one well in an agricultural area in southwestern Georgia that taps the unconfined Upper Floridan aquifer. These simulations highlight the lag time between activities at the land surface and changes in the water quality of the aquifer. Under the first scenario, nitrate concentrations in groundwater are predicted to increase by about $3 \mathrm{mg} / \mathrm{L}$ as nitrogen over a period of about 30 years to about $13 \mathrm{mg} / \mathrm{L}$ and to remain at that level into the future. Under the second scenario, even though inputs do not increase, nitrate concentrations in groundwater are predicted to continue to increase for about 30 years before beginning to decline. Under the third scenario, nitrate concentrations continue to increase for about 15 years with no nitrogen inputs, and concentrations decrease to about half of the current concentration within about 30 years.

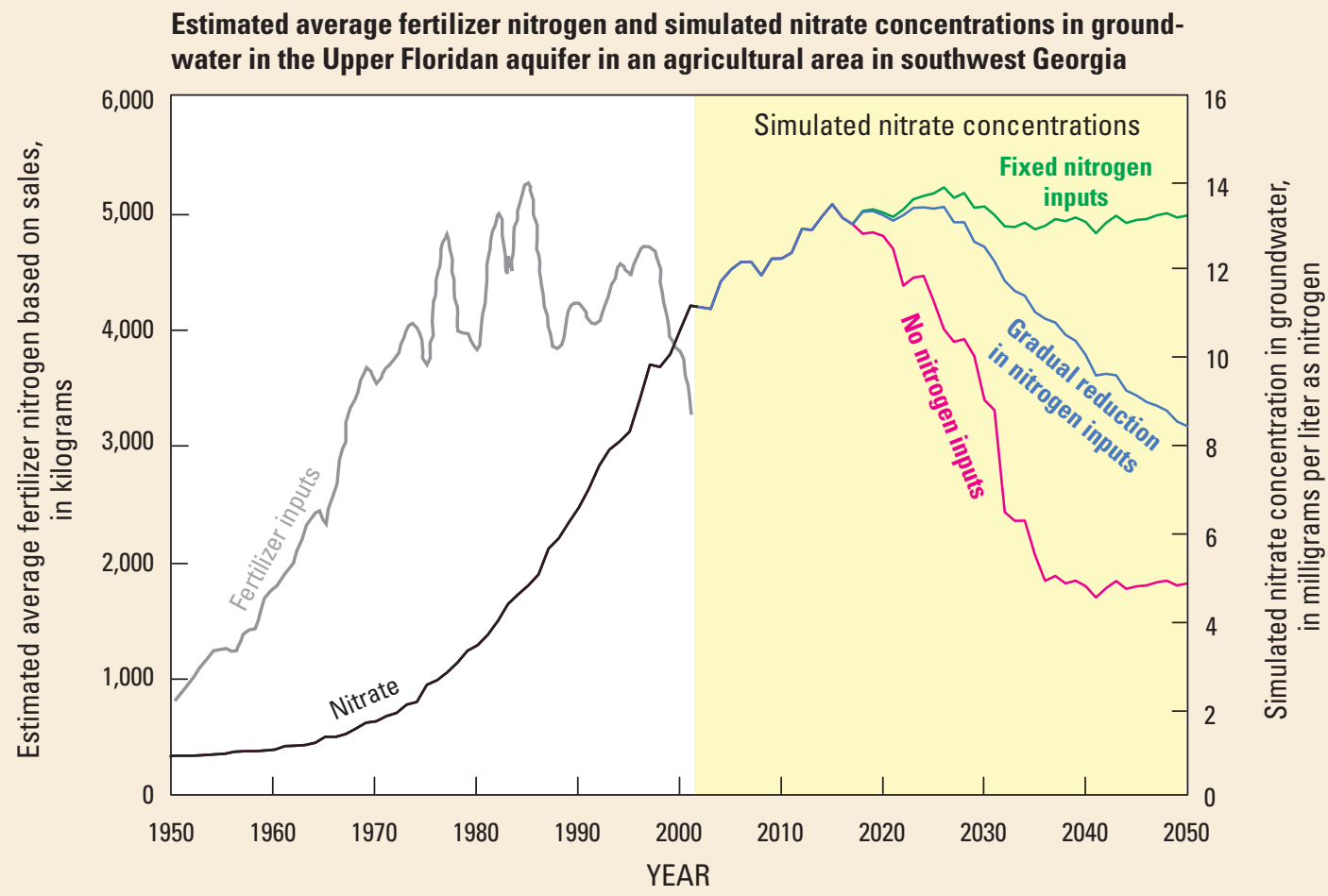




\section{Pesticides}

Pesticides, used to control weeds, insects, and other pests in agricultural and urban areas, can leach into the surficial aquifers, which provide recharge to the Upper Floridan aquifer. Pesticides are detected most commonly in those parts of the Upper Floridan aquifer that are overlain by areas of intensive pesticide use and where the Upper Floridan aquifer is unconfined and has numerous karst features. At least one pesticide was detected in nearly half of the public-supply wells and 13 percent of the domestic wells sampled in the Upper Floridan aquifer, but concentrations of only one insecticide - dieldrin - exceeded a human-health benchmark and dieldrin was detected in only about 1 percent of samples. Overall, concentrations of pesticides were very low (less than $0.1 \mu \mathrm{g} / \mathrm{L}$ ) and were well below human-health benchmarks.

\section{Pesticides were detected frequently in wells in the surficial aquifers, typically as mixtures of two or more}

At least one pesticide was detected in 55 percent of the wells in the surficial aquifers underlying agricultural and urban areas. The herbicide atrazine and its degradate, deethylatrazine, were detected most commonly in about 25 percent of wells (more than any other pesticides). Concentrations of almost all pesticides were less than human-health benchmarks, with the exception of dieldrin, which exceeded its human-health benchmark of $0.002 \mu \mathrm{g} / \mathrm{L}$ in two samples. The occurrence of dieldrin in groundwater more than 20 years after its use was banned is evidence of how persistent this chemical is in the environment.

Two or more pesticides were detected in 42 percent of samples from shallow groundwater in the surficial aquifers underlying agricultural areas and 24 percent of samples from shallow groundwater underlying urban areas (fig. 6-8). The occurrence of two or more pesticides in groundwater from surficial aquifers used for drinking is a potential health concern, even at concentrations below human-health benchmarks, because the potential health effects of such mixtures are not well understood. ${ }^{(50)}$ The vulnerability of the surficial aquifers to pesticide contamination is a concern for households that use domestic wells as a source of drinking water and also is a concern because these aquifers provide recharge to the Upper Floridan aquifer.

\section{Similar pesticides were detected in the surficial and Upper Floridan aquifers}

Atrazine (and its degradates) and metolachlor each were detected in 10 percent or more of samples from both the surficial and Upper Floridan aquifers (fig. 6-9). Atrazine and metolachlor, which are used to control weeds in agricultural and urban (residential and commercial) areas, respectively, are two of the most heavily used herbicides in the Nation and two of the herbicides most commonly detected in groundwater. ${ }^{(51)}$ Bentazon, prometon, and tebuthiuron were detected in at least 5 percent of samples from both aquifers. It is not surprising that similar pesticides were detected in both aquifers given that the surficial aquifers are an important source of recharge to the Upper Floridan aquifer, but it nonetheless confirms the vulnerability of the Upper Floridan aquifer to contamination from the overlying surficial aquifers.

Concentrations of the pesticides detected in the Upper Floridan aquifer were low and none exceeded a human-health benchmark. Although atrazine was detected in more than 15 percent of samples from the Upper Floridan aquifer, concentrations were lower than those from many other Principal Aquifers sampled across the Nation (appendix 3). 


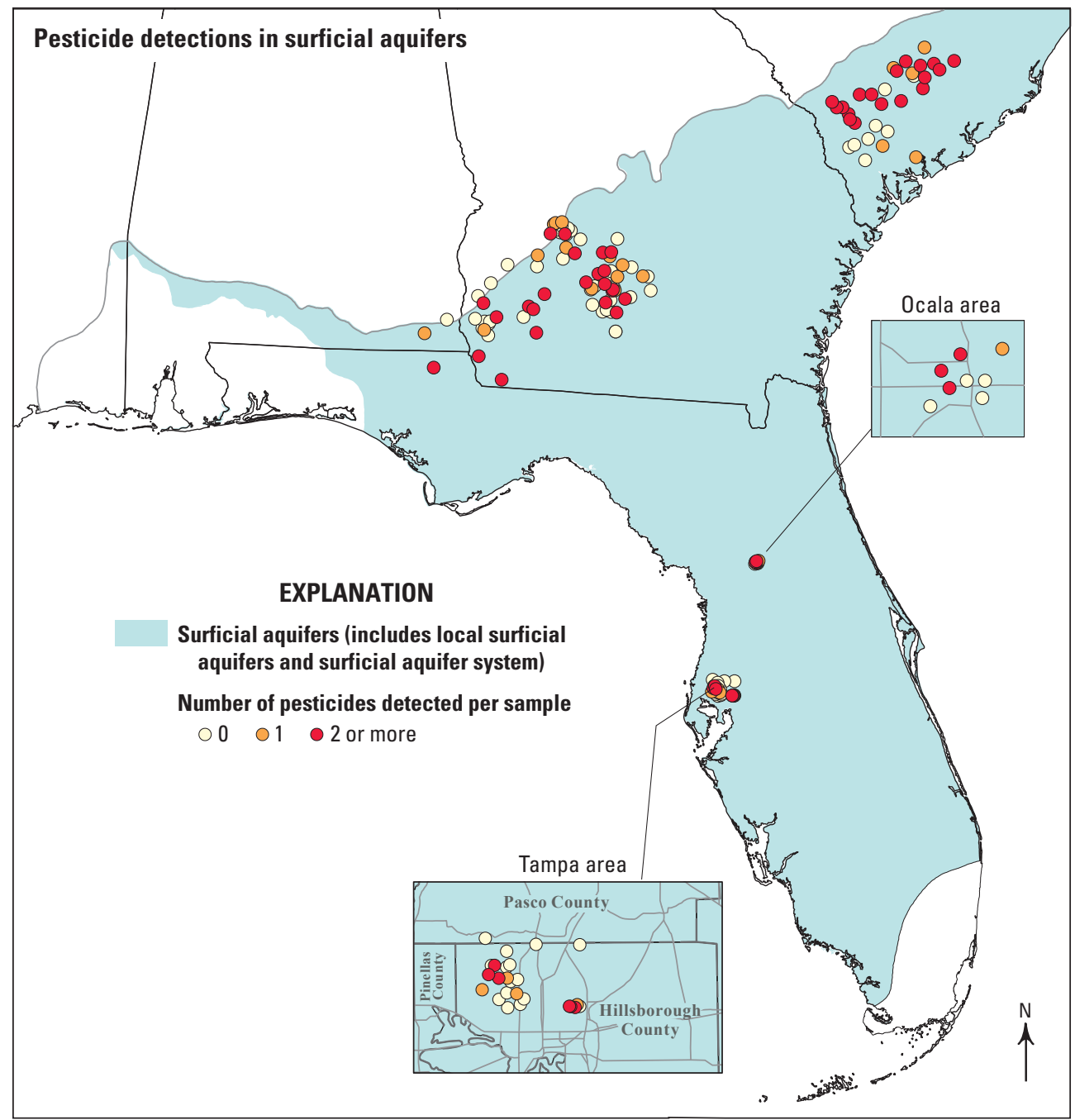

Pesticide detections in surficial aquifers by land-use study type

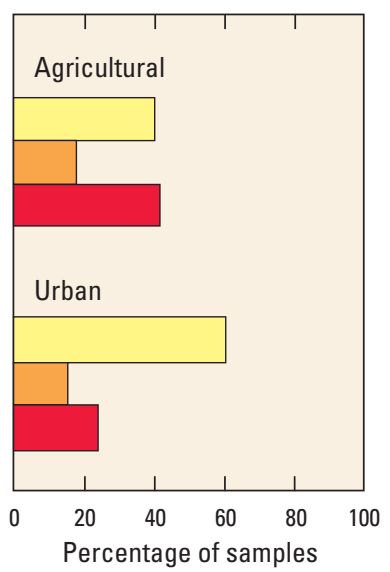

EXPLANATION

Number of pesticides detected

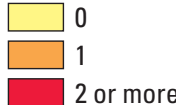

Figure 6-8. Two or more pesticides were detected frequently in shallow groundwater in the surficial aquifers underlying urban and agricultural areas. The vulnerability of the surficial aquifers to pesticide contamination is a concern for households that rely on domestic wells as a source of drinking water.

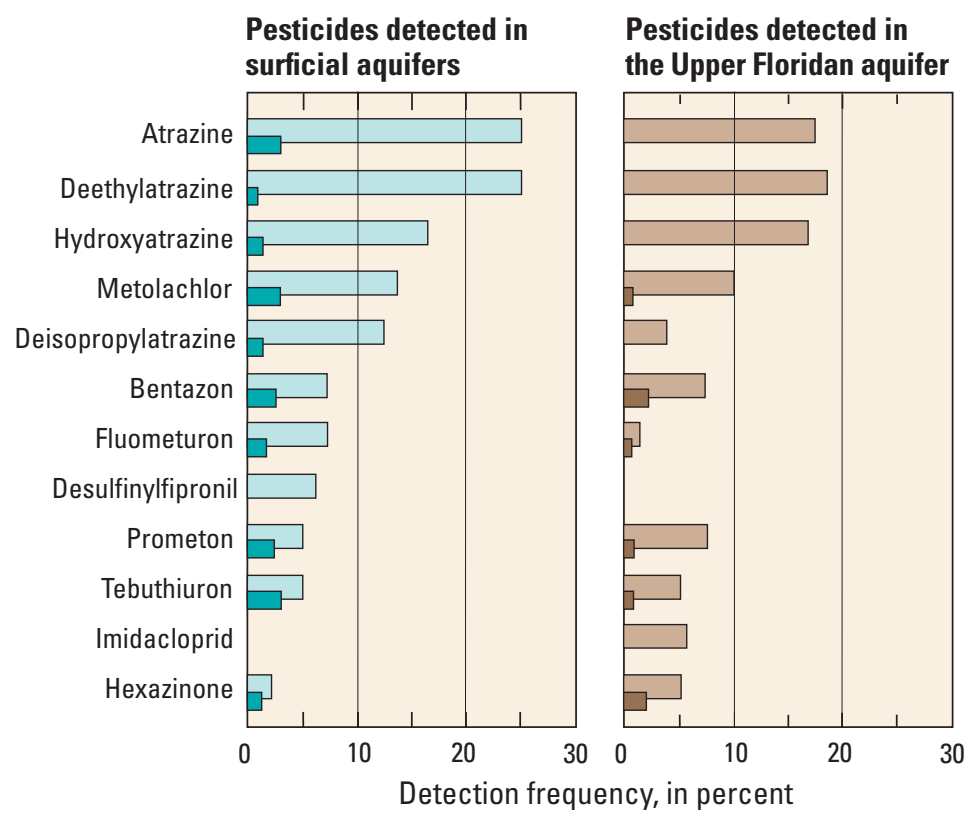

Figure 6-9. Pesticide occurrence was similar in samples from the surficial and Upper Floridan aquifers, but concentrations typically were higher in the surficial aquifers. Atrazine and metolachlor are among the pesticides with the largest use in the Nation and were among the herbicides most commonly detected in the study area.

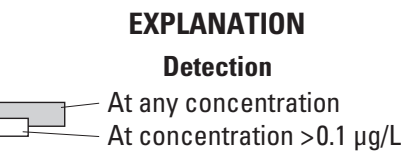




\section{Hydrogeology and rates of pesticide use affect the vulnerability of the Upper Floridan aquifer to pesticide contamination}

The occurrence of pesticides in the Upper Floridan aquifer is related to hydrogeologic conditions and intensity of pesticide use. The absence of a confining layer and the presence of karst features, such as sinkholes, facilitate the transport of any pesticides used to the Upper Floridan aquifer. In areas where the confining layer is absent, one or more pesticides were detected in more than 60 percent of the wells sampled (fig. 6-10). Differences in the intensity of pesticide use across the study area also are reflected in the occurrence of pesticides in
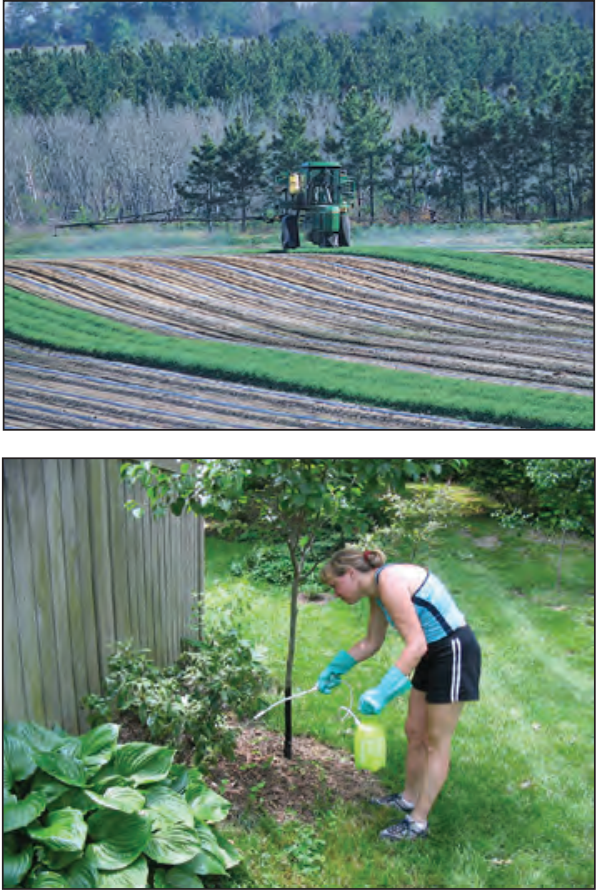

Pesticides used in agricultural and urban areas were detected frequently in both the surficial and Upper Floridan aquifers. groundwater. In southwestern Georgia where agriculture is the predominant land use (fig. 3-5), two or more pesticides were detected in more than half of the wells sampled (fig. 6-10).

The influence of hydrogeology on groundwater vulnerability to contamination is further illustrated by pesticide occurrence in the Upper Floridan aquifer in southwestern and southeastern Georgia. Both of these areas are characterized by agricultural land use, but the hydrogeologic characteristics of the Upper Floridan aquifer in the two areas differ. In southwestern Georgia, the Upper Floridan aquifer is relatively shallow, is unconfined, and has numerous karst features. Two or more pesticides were detected in southwestern Georgia in more than half of the wells sampled. In contrast, in southeastern Georgia, the Upper Floridan aquifer is relatively deep, is confined, and has few karst features. A pesticide was detected in only two wells in southeastern Georgia. The lack of a confining layer and the presence of karst features - sinkholes and conduits facilitate the movement of pesticides into the Upper Floridan aquifer.

Where hydrogeology is similar, differences in pesticide use contribute to pesticide occurrence. The Upper Floridan aquifer is unconfined in both southwest Georgia and west-central Florida, and the depths of the wells sampled in these areas are comparable. Agricultural land use and pesticide use, however, are much more intense in southwest Georgia than in west-central Florida-the amount of atrazine applied to crops in areas near wells in southwest Georgia was estimated to be more than 10 times greater than in west-central Florida. ${ }^{(52)}$ These patterns of use are reflected in the much more common detection of pesticides in wells in southwest Georgia than in those in west-central Florida. For example, atrazine was detected in about half of the wells sampled in southwest Georgia, but in only one well in the west-central Florida area.
Pesticides were detected in nearly 40 percent of public-supply wells in the Upper Floridan aquifer.

\section{Pesticides used in urban areas are a source of contamination to the Upper Floridan aquifer}

In the Tampa area, pesticides were detected commonly in shallow parts of the Upper Floridan aquifer and also in the deeper parts of the aquifer that are used for public water supply. Pesticides are used in residential and commercial areas to control weeds, insects, and other pests in lawns, landscaping, parks, and golf courses, and along roads and other rights-of-way. ${ }^{(51)}$ At least one pesticide was detected in almost 60 percent of samples of shallow groundwater from monitoring wells in the Upper Floridan aquifer and in nearly 40 percent of samples from public-supply wells in urban areas (fig. 6-11). About 40 percent of the samples in which pesticides were detected in shallow groundwater had concentrations above $0.1 \mu \mathrm{g} / \mathrm{L}$, but all of the pesticide concentrations detected in the public-supply wells were less than this common assessment level. The occurrence of pesticides indicates that the deep parts of the Upper Floridan aquifer used for water supply in the Tampa area likely are vulnerable to contamination because the aquifer in this area largely is unconfined and because karst features provide a pathway from the land surface directly into the aquifer. 
Pesticide detections in the Upper Floridan aquifer

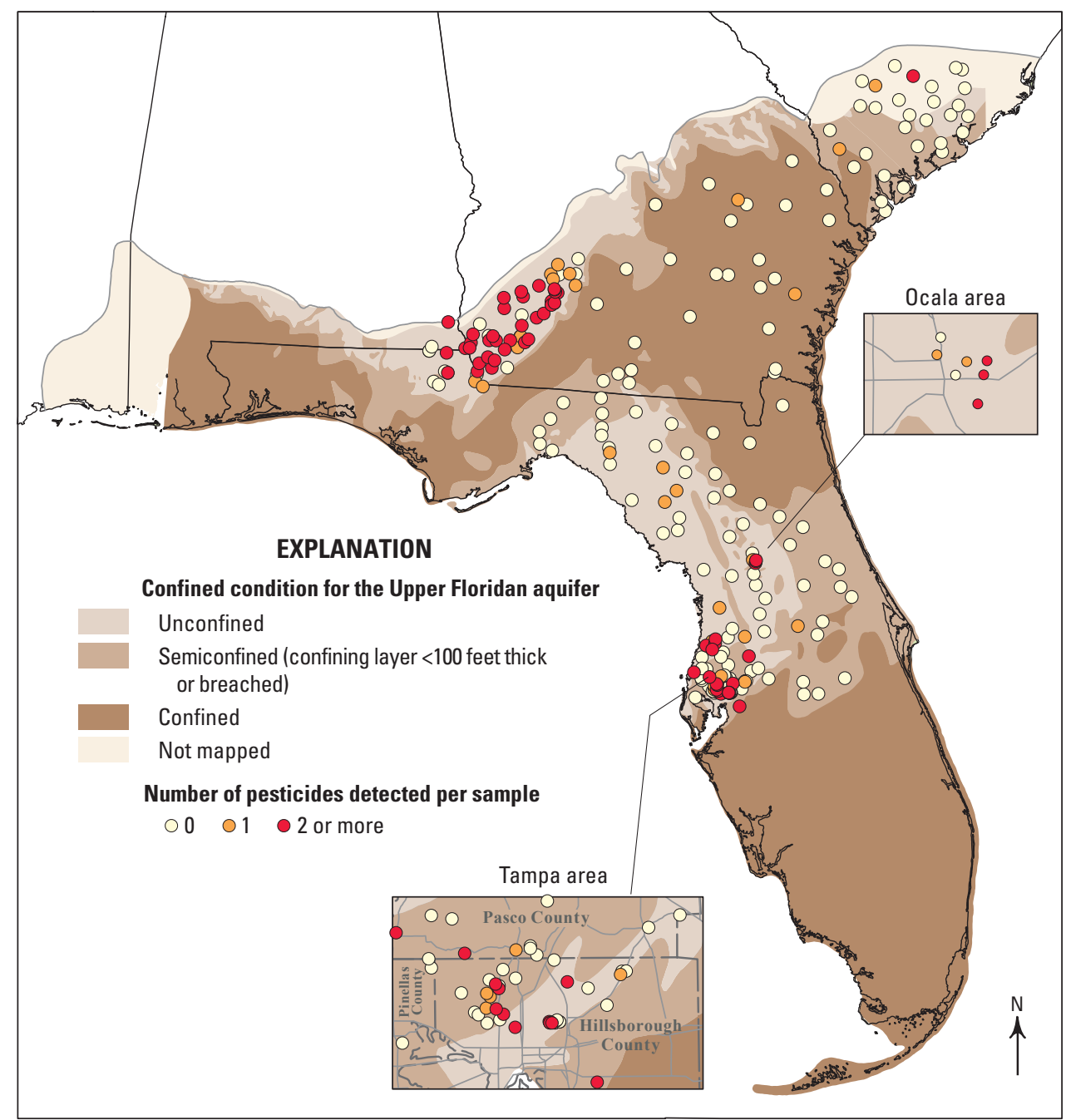

Pesticide detections by confined condition in the Upper Floridan aquifer

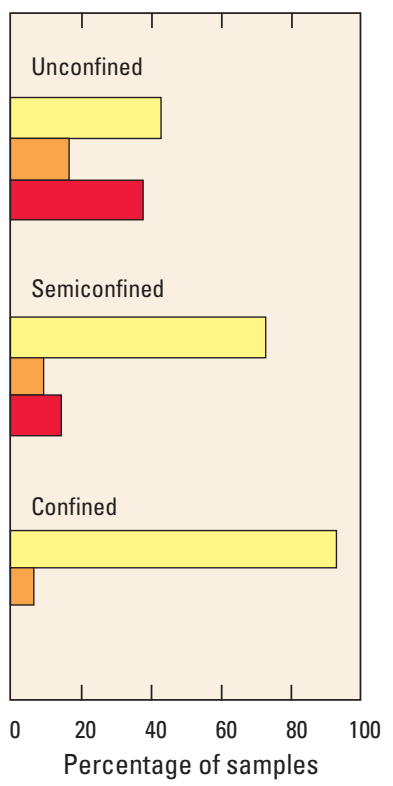

EXPLANATION

Number of pesticides detected

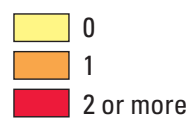

Figure 6-10. Pesticides were detected most commonly in samples from the Upper Floridan aquifer where the upper confining layer that limits the downward movement of water and contaminants is absent, but were rarely detected where the aquifer is confined. The presence of karst features in areas where the aquifer is unconfined contributes to the transport of pesticides from the land surface into the Upper Floridan aquifer.

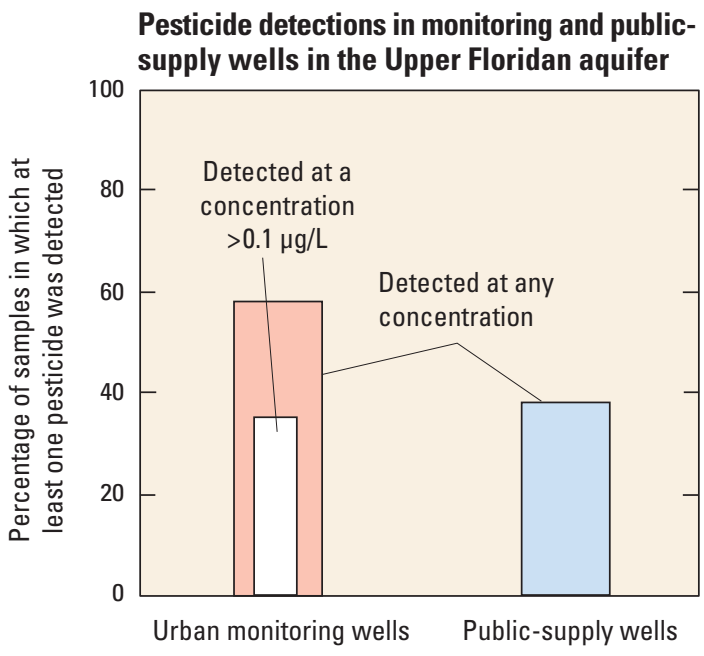

Figure 6-11. In urban areas, pesticides were detected commonly in shallow groundwater and in deep groundwater used for drinking. Pesticide concentrations, however, were higher in shallow than in deep groundwaternearly 40 percent of samples of shallow groundwater had at least one pesticide at a concentration greater than $0.1 \mu \mathrm{g} / \mathrm{L}$, but no samples from public-supply wells had a pesticide concentration greater than $0.1 \mu \mathrm{g} / \mathrm{L}$. 


\section{References Cited}

1. Gilliom, R.J., Alley, W.M., and Gurtz, M.E., 1995, Design of the National Water-Quality Assessment ProgramOccurrence and distribution of water-quality conditions: U.S. Geological Survey Circular 1112, 33 p., accessed August 14, 2013, at http://pubs.usgs.gov/circ/circ1112/.

2. Hopple, J.A., Delzer, G.C., and Kingsbury, J.A., 2009, Anthropogenic organic compounds in source water of selected community water systems that use groundwater, 2002-05: U.S. Geological Survey Scientific Investigations Report 2009-5200, 74 p., accessed August 12, 2013, at http://pubs.usgs.gov/sir/2009/5200/.

3. Eberts, S.M., Thomas, M.A., and Jagucki, M.L., 2013, The quality of our Nation's waters-Factors affecting public-supply-well vulnerability to contaminationUnderstanding observed water quality and anticipating future water quality: U.S. Geological Survey Circular 1385, 120 p. (Also available at $h t t p: / / p u b s . u s g s . g o v / c i r c / 1385 /$.)

4. Bush, P.W., and Johnston, R.H., 1988, Ground-water hydraulics, regional flow, and ground-water development of the Floridan aquifer system in Florida and parts of Georgia, South Carolina, and Alabama: U.S. Geological Survey Professional Paper 1403-C, 80 p.

5. Rosenau, J.C., Faulkner, G.L., Hendry, C.W., and Hull, R.W., 1977, Springs of Florida: Tallahassee, Fla., Florida Geological Survey Bulletin 31 (revised), 461 p.

6. Miller, J.A., 1990, Ground water atlas of the United States, segment 6, Alabama, Florida, Georgia, and South Carolina: U.S. Geological Survey Hydrologic Investigation Atlas 730-G, 28 p.

7. Miller, J.A., 1986, Hydrogeologic framework of the Floridan aquifer system in Florida and in parts of Georgia, Alabama, and South Carolina: U.S. Geological Survey Professional Paper 1403-B, 91 p.

8. Sepúlveda, Nicasio, 2002, Simulation of ground-water flow in the intermediate and Floridan aquifer systems in peninsular Florida: U.S. Geological Survey WaterResources Investigations Report 02-4009, 130 p.

9. Georgia Department of Natural Resources, 2006, Flint River Basin regional water development and conservation plan: Atlanta, Ga., Georgia Environmental Protection Division, Georgia Department of Natural Resources, 232 p.

10. Hodges, A.W., Rahmani, Mohammad, and Stevens, T.J., 2011, Economic contributions of agriculture, natural resources, and related industries in Florida in 2009: Gainesville, Fla., University of Florida, Institute for Food and Agriculture Studies, Florida Cooperative Extension Service, Food and Resources Economics Department EDIS FE897, 19 p.
11. Marella, R.L., 2009, Water withdrawals, use, and trends in Florida, 2005: U.S. Geological Survey Scientific Investigations Report 2009-5125, 49 p.

12. Marella, R.L., and Berndt, M.P., 2005, Water withdrawals and trends from the Floridan aquifer system in the southeastern United States, 1950-2000: U.S. Geological Survey Circular 1278, 20 p.

13. Berndt, M.P., Oaksford, E.T., and G.L., Mahon, 1998, Groundwater, in Fernald, E.A., and Purdum, E.D., eds., Water resources atlas of Florida: Tallahassee, Florida, Florida State University, Institute of Science and Public Affairs, p. 38-63.

14. Florida Department of Environmental Protection, 2010, Desalination in Florida-Technology, implementation, and environmental issues: Tallahassee, Fla., Florida Department of Environmental Protection, 109 p., accessed November 21, 2013, at http://www.dep.state.fl.us/water/ docs/desalination-in-florida-report.pdf.

15. Dalton, M.S., and Frick, D.A., 2008, Fate and transport of pesticides in the ground water systems of southwest Georgia, 1993-2005: Journal of Environmental Quality, v. 37, p. S-264-S-272.

16. Barlow, P.M., 2003, Ground water in freshwater-saltwater environments of the Atlantic coast: U.S. Geological Survey Circular 1262, 113 p., accessed August 16, 2013, at http://pubs.usgs.gov/circ/2003/circ1262/.

17. Purdum, E.D., and Penson, Georgann, 1998, Northwest Florida water management district, in Fernald, E.A., and Purdum, E.D., eds., Water resources atlas of Florida: Tallhassee, Fla., Florida State University, Institute of Science and Public Affairs, p. 170-193.

18. Krause, R.E., and Clarke, J.S., 2001, Coastal ground water at risk-Saltwater contamination at Brunswick, Georgia, and Hilton Head Island, South Carolina: U.S. Geological Survey Water-Resources Investigations Report 01-4107, poster.

19. Bradner, L.A., 1991, Water quality in the Upper Floridan Aquifer in the vicinity of drainage wells, Orlando, Florida: U.S. Geological Survey Water-Resources Investigations Report 90-4175, $57 \mathrm{p}$.

20. Berndt, M.P., Galeone, D.R., Spruill, T.B., and Crandall, C.A., 1998, Ground-water quality in three urban areas in the Coastal Plain of the southeastern United States, 1995: U.S. Geological Survey WaterResources Investigations Report 97-4234, 25 p.

21. Cecil, L.D., and Green, J.R., 2000, Radon-222, in Cook, P.G., and Herczeg, A.L., eds., Environmental tracers in subsurface hydrology: Boston, Mass., Kluwer Academic Publishers, chap. 6, p. 175-194. 
22. U.S. Environmental Protection Agency, 2009, Proposed radon in drinking water rule: U.S. Environmental Protection Agency Web site, accessed February 24, 2010, at http://www.epa.gov/safewater/radon/proposal.html.

23. U.S. Environmental Protection Agency, 1999, Proposed radon in drinking water rule: U.S. Environmental Protection Agency Technical Fact Sheet 815-F-99-006, 6 p., accessed February 8, 2012, at http://www.epa.gov/ ogwdw000/radon/fact10.pdf.

24. Berndt, M.P., and Crandall, C.A., 2009, Factors affecting water quality in domestic wells in the Upper Floridan aquifer, southeastern United States, 1998-2005: U.S. Geological Survey Scientific Investigations Report 2009-5147, 39 p.

25. Katz, B.G., Crandall, C.A., Metz, P.A., McBride, W.S., and Berndt, M.P., 2007, Chemical characteristics, water sources and pathways, and age distribution of ground water in the contributing recharge area of a public-supply well near Tampa, Florida, 2002-05: U.S. Geological Survey Scientific Investigations Report 2007-5139, 83 p.

26. Smith, A.H., Hopenhayn-Rich, C., Bates, M.N., Goeden, H.M., Hertz-Picciotto, I., Duggan, H.M., Wood, R., Kosnett, M.J., and Smith, M.T., 1992, Cancer risks from arsenic in drinking water: Environmental Health Perspectives, v. 97, p. 259-267.

27. National Academy of Sciences, 2001, Arsenic in drinking water, 2001 update: Washington, D.C., National Academy Press, $225 \mathrm{p}$.

28. Pichler, T., Price, R., Lazareva, O., and Dippold, A., 2011, Determination of arsenic concentration and distribution in the Floridan aquifer system: Journal of Geochemical Exploration, v. 111, no. 3, p. 84-96.

29. Reese, R.S., and Alvarez-Zarikian, C.A., 2007, Hydrogeology and aquifer storage and recovery performance in the Upper Floridan Aquifer, southern Florida: U.S. Geological Survey Scientific Investigations Report 2006-5239, 117 p.

30. Florida Geological Survey, 2011, Aquifer storage and recovery geochemical studies: Florida Department of Environmental Protection Web site, accessed November 20, 2013, at http://www.dep.state.fl.us/ geology/programs/hydrogeology/aquifer_storage.htm.

31. Arthur, J.D., Dabous, A.A., and Cowart, J.B., 2005, Water-rock geochemical consideration for aquifer storage and recovery-Florida case studies, in Tsang, C.F., and Apps, J.A., eds., Underground injection science and technology, developments in water science: Amsterdam, Netherlands, Elsevier, v. 52, p. 327-339.

32. U.S. Environmental Protection Agency, 2006, 2006 edition of the drinking water standards and health advisories: U.S. Environmental Protection Agency Office of Water EPA 822-R-06-013, 18 p.
33. National Research Council, 1999, Risk assessment of radon in drinking water: Washington, D.C., National Academy Press, 296 p.

34. Maddox, G.L., Lloyd, J.M., Scott, T.M., Upchurch, S.B., and Copeland, Rick, eds., 1992, Florida's Ground-Water Quality Monitoring Network Program-Background hydrogeochemistry: Tallahassee, Fla., Florida Geological Survey Special Publication 34, 68 p., plus tables.

35. Berndt, M.P., 1996, Ground-water quality assessment of the Georgia-Florida Coastal Plain study unit-Analysis of available information on nutrients, 1972-92: U.S. Geological Survey Water-Resources Investigations Report 95-4039, 39 p.

36. Florida Department of Environmental Protection, 2012, Implementation of Florida's numeric nutrient standards: Tallahassee, Fla., Florida Department of Environmental Protection, 81 p., accessed November 21, 2013, at http://www.dep.state.fl.us/water/wqssp/nutrients/docs/ nnc_implementation.pdf.

37. Scott, T.M., Means, G.H., Meegan, R.P., Upchurch, S.B., Copeland, R.E., Jones, James, Roberts, Tina, and Willet, Alan, 2004, Springs of Florida: Tallahassee, Fla., Florida Geological Survey Bulletin 66, 377 p.

38. Walsh, S.J., 2001, Freshwater macrofauna in Florida karst habitats, in Kuniansky, E.L., ed., U.S. Geological Survey Karst Interest Group proceedings, St. Petersburg, Florida, February 13-16, 2001: U.S. Geological Survey WaterResources Investigations Report 01-4011, p. 78-88.

39. Harrington, Debra, Maddox, Gary, and Hicks, Richard, 2010, Florida springs initiative monitoring network report and recognized sources of nitrate: Tallahassee, Fla., Florida Department of Environmental Protection, 103 p.

40. Pittman, J.R., Hatzell, H.H., and Oaksford, E.T., 1997, Spring contributions to water quality and nitrate loads in the Suwannee River during baseflow in July 1995: U.S. Geological Survey Water-Resources Investigations Report 97-4152, 12 p.

41. Upchurch, S.B., Chen, Jian, and Cain, C.R., 2007, Trends of nitrate concentrations in waters of the Suwannee River water management district, 2007: Live Oak, Fla., Suwannee River Water Management District, 36 p.

42. Katz, B.G., Sepulveda, A.A., and Verdi, R.J., 2009, Estimating nitrogen loading to ground water and assessing vulnerability to nitrate contamination in a large karstic springs basin, Florida: Journal of the American Water Resources Association, v. 45, no. 3, p. 607-627.

43. Heffernan, J.B., Liebowitz, D.M., Frazer, T.K., Evans, J.M., and Cohen, M.J., 2010, Algal blooms and the nitrogen-enrichment hypothesis in Florida springsEvidence, alternatives, and adaptive management: Ecological Applications, v. 20, no. 3, p. 816-829. 
44. Jones, G.W., Upchurch, S.B., Champion, K.M., DeHaven, E.C., Starks, Roberta, Dejongh, Lisa, Tomlinson, Chris, Hood, Jason, Anastasiou, Chris, and Miller, E.J., 1996, Origin of nitrate in ground water discharging from Rainbow Springs, Marion County, Florida: Brooksville, Fla., Southwest Florida Water Management District, 155 p.

45. Florida Springs Task Force, 2000, Florida's springsStrategies for protection \& restoration: Florida Department of Environmental Protection Web site, accessed November 21, 2013, at http://www.dep.state.fl.us/ springs/reports/index.htm.

46. Katz, B.G., Hornsby, H.D., Böhlke, J.F., and Mokray, M.F., 1999, Sources and chronology of nitrate contamination in spring waters, Suwannee River Basin, Florida: U.S. Geological Survey Water-Resources Investigation Report 99-4252, 54 p.

47. Katz, B.G., 2004, Sources of nitrate contamination and age of water in large karstic springs of Florida: Environmental Geology, v. 46, nos. 67, p. 689-706.

48. Katz, B.G., Böhlke, J.K., and Hornsby, H.D., 2001, Timescales for nitrate contamination of spring waters, northern Florida, USA: Chemical Geology, v. 179, nos. 1-4, p. 167-186.

49. Crandall, C.A., Katz, B.G., and Berndt, M.P., 2013, Estimating nitrate concentrations in groundwater at selected wells and springs in the surficial aquifer system and Upper Floridan aquifer, Dougherty Plain and Marianna Lowlands, Georgia, Florida, and Alabama, 2002-50: U.S. Geological Survey Scientific Investigations Report 2013-5150, 65 p., accessed November 21, 2013, at http://pubs.usgs.gov/sir/2013/5150/.

50. Toccalino, P.L., and Hopple, J.A., 2010, The quality of our Nation's waters-Quality of water from public-supply wells in the United States, 1993-2007-Overview of major findings: U.S. Geological Survey Circular 1346, $58 \mathrm{p}$.

51. Gilliom, R.J., Barbash, J.E., Crawford, C.G., Hamilton, P.A., Martin, J.D., Nakagaki, Naomi, Nowell, L.H., Scott, J.C., Stackelberg, P.E., Thelin, G.P., and Wolock, D.M., 2006, The quality of our Nation's waters-Pesticides in the nation's streams and ground water, 1992-2001: U.S. Geological Survey Circular 1291, 172 p. (Also available at http://pubs.usgs.gov/circ/2005/1291/.)

52. Katz, B.G., Berndt, M.P., and Crandall, C.A., 2013, Factors affecting the movement and persistence of nitrate and pesticides in the surficial and Upper Floridan aquifers in two agricultural areas in the southeastern United States: Environmental Earth Sciences, v. 71, p. 2779-2795.
53. Otton, J.K., Gundersen, L.C.S., and Schumann, R.R., 1993, The geology of radon: U.S. Geological Survey General Interest Publication, 29 p.

54. U.S. Environmental Protection Agency, 1994, Evaluating and identifying contaminants of concern for human health: U.S. Environmental Protection Agency Hazardous Waste Management Division Region 8 Superfund Technical Guidance RA-03, 10 p., accessed September 23, 2013, at http://www2.epa.gov/sites/ production/files/documents/r8_ra03-cocs.pdf.

55. New Jersey Department of Environmental Protection, 2003, Susceptibility of source water to community water-supply wells in New Jersey to contamination by volatile organic compounds: New Jersey Department of Environmental Protection, 21 p. (Also available at http://www.state.nj.us/dep/swap/reports/gw_voc.pdf.)

56. Toccalino, P.L., Norman, J.E., Phillips, R.H., Kauffman, L.J., Stackelberg, P.E., Nowell, L.H., Krietzman, S.J., and Post, G.B., 2004, Application of health-based screening levels to ground-water quality data in a state-scale pilot effort: U.S. Geological Survey Scientific Investigations Report 2004-5174, 64 p.

57. Toccalino, P.L., 2007, Development and application of health-based screening levels for use in water-quality assessments: U.S. Geological Survey Scientific Investigations Report 2007-5106, 12 p.

58. Toccalino, P.L., Norman, J.E., Booth, N.L., Thompson, J.L., and Zogorski, J.S., 2012, Health-based screening levelsBenchmarks for evaluating water-quality data: U.S. Geological Survey Web site, accessed April 24, 2013, at http://water.usgs.gov/nawqa/HBSL/.

59. U.S. Environmental Protection Agency, [undated], National primary drinking water regulations-Drinking water contaminants: U.S. Environmental Protection Agency Web site, accessed May 25, 2012, at http://water.epa.gov/drink/contaminants/index.cfm.

60. U.S. Environmental Protection Agency, [undated], Secondary drinking water regulations-Guidance for nuisance chemicals: U.S. Environmental Protection Agency 816-F-10-079, accessed April 24, 2013, at http://water.epa.gov/drink/contaminants/ secondarystandards.cfm.

61. Homer, C.H., Fry, J.A., and Barnes, C.A., 2012, The National Land Cover Database: U.S. Geological Survey Fact Sheet 2012-3020, 4 p. (Also available at http://pubs.usgs.gov/fs/2012/3020/fs2012-3020.pdf.)

62. DeSimone, L.A., McMahon, P.B., and Rosen, M.R., 2014, The quality of our Nation's waters - Summary of water quality in Principal Aquifers of the United States, 1991-2010: U.S. Geological Survey Circular 1360, 151 p. (Also available at http://dx.doi.org/10.3133/cir1360.) 


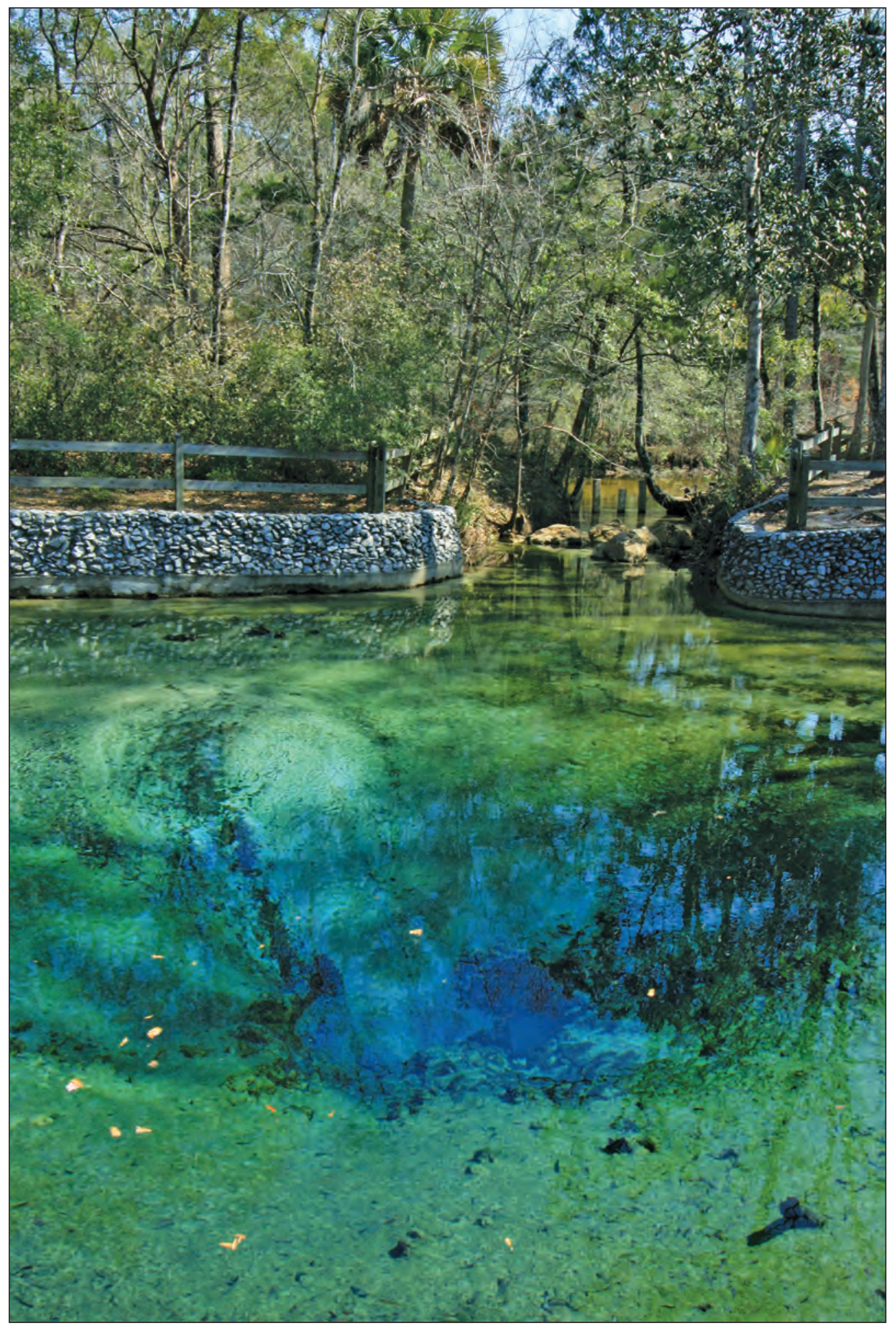

Pitt Spring, Bay County, Florida. 


\section{Glossary}

\section{A}

anoxic Water with no dissolved oxygen or a very low concentration (less than 0.5 milligram per liter) of dissolved oxygen.

apparent groundwater age The time elapsed since the recharge water became isolated from the atmosphere. The term "age" is normally qualified with the word "apparent" to signify that the accuracy of the determined age depends on many variables.

aquifer A geologic formation, group of formations, or part of a formation that contains a sufficient amount of saturated permeable material (for example, soil, sand, gravel and (or) rock) to yield substantial quantities of water to wells and springs.

\section{C}

carbonate rock Rocks, such as limestone or dolostone, that are composed primarily of minerals, such as calcite and dolomite, containing the carbonate ion $\left(\mathrm{CO}_{3}{ }^{2-}\right)$.

common assessment level A single concentration threshold used to establish an equal basis for comparing detection frequencies among multiple chemicals. Use of a common assessment level avoids biases in detection frequencies caused by one compound having a lower detection level than another. Also sometimes referred to as a "common detection level."

conduit/conduit flow Groundwater flow through pipe-like or channel-like openings in bedrock. Conduits control the direction of water flow and greatly increase the speed at which water travels through an aquifer. confined aquifer (artesian aquifer) An aquifer in which the groundwater is bounded between layers of relatively impermeable material, such as clay or dense rock. When tapped by a well, water in a confined aquifer is forced up, sometimes above the land surface, by pressure within the aquifer.

confining layer Geologic material with little or no permeability or hydraulic conductivity. Water does not pass through this layer or the rate of movement is extremely slow.

\section{D}

degradate A compound formed by the transformation of a parent compound, typically an organic contaminant or another degradate, by chemical, photochemical, or biological reactions.

denitrification The bacterial reduction of dissolved nitrate to nitrogen gas.

Denitrification is the primary process by which nitrate can be eliminated naturally in groundwater.

domestic well A privately owned well that typically serves one home and supplies water for human consumption and other homeowner uses.

\section{$\mathbf{F}$}

flow path The route or pathway of water flowing through the hydrologic system. Typically refers to subsurface (groundwater) flow.

\section{G}

groundwater Water that exists beneath the land surface, but most commonly refers to water in fully saturated soils and geologic formations.

groundwater age See apparent groundwater age.

groundwater flow path See flow path. 
H

\section{Health-Based Screening Level (HBSL)}

An estimate of concentration (for a noncarcinogen) or concentration range (for a carcinogen) in water that (1) may be of potential human-health concern, (2) can be used as a threshold value against which measured concentrations of contaminants in ambient groundwater samples can be compared, and (3) is consistent with U.S. Environmental Protection Agency Office of Water methodologies.

human-health benchmark A threshold concentration above which the concentration of a contaminant in drinking water could have adverse effects on human health. Treatment or other measures can be used before the water is consumed to lower the concentration of the contaminant below the benchmark.

hydrogeologic unit A body of rock distinguished and characterized by its porosity and permeability. Also called a hydrostratigraphic unit.

hydrogeology The geologic and hydrologic features that control the movement of water, solutes, and small particles through the subsurface.

\section{K}

karst Surface and subsurface terrane that is formed on and in soluble rocks, such as limestone and gypsum, primarily by dissolution and collapse, and that is characterized by sinkholes, caves, and underground drainage.

\section{L}

land-use study A study by the U.S. Geological Survey National Water-Quality Assessment (NAWQA) Program to assess the effects of a specific land-use type (generally agricultural or urban) on groundwater quality, in most cases by sampling groundwater from monitoring wells that tap water from or near the water table.

lithology The physical character of a rock on the basis of color, structure, mineralogical composition, grain size, and other characteristics.

\section{M}

major aquifer A regionally extensive subsurface geologic formation or group of formations that is used, or has the potential to be used, as a substantial groundwater resource.

major aquifer study A study by the U.S. Geological Survey National Water-Quality Assessment (NAWQA) Program that involves sampling of water at 20 to 30 domestic and (or) public-supply wells that withdraw water from major aquifers. The major aquifer studies represent a mix of land uses and target water that is used for drinking-water supply.

\section{Maximum Contaminant Level (MCL)}

Maximum permissible level of a contaminant in water that is delivered to any user of a public water system. MCLs are enforceable standards established by the U.S. Environmental Protection Agency.

milligrams per liter (mg/L) A unit expressing the concentration of a chemical constituent as weight (milligrams) of constituent per unit volume (liter) of water; equivalent to one part per million in most streamwater and groundwater. One thousand micrograms per liter $(\mu \mathrm{g} / \mathrm{L})$ is equivalent to $1 \mathrm{mg} / \mathrm{L}$.

monitoring well A well used to measure water quality or groundwater levels continuously or periodically. Not typically used as a source of drinking water. Sometimes referred to as an "observation well."

\section{$\mathbf{0}$}

oxic Water with a concentration of dissolved oxygen greater than or equal to 0.5 milligram per liter.

\section{$\mathbf{P}$}

pesticide Any substance, organic or inorganic, used to kill plant or animal pests.

pH A measure of the acidity ( $\mathrm{pH}$ less than 7) or alkalinity ( $\mathrm{pH}$ greater than 7 ) of a solution; a pH of 7 is neutral. Formally defined as the logarithm of the reciprocal of the hydrogen ion concentration (activity) of a solution. 
Principal Aquifer A regionally extensive aquifer or aquifer system that has the potential to be used as a source of potable water. A Principal Aquifer can be composed of one or more major aquifers.

public-supply well A privately or publicly owned well that provides water for public use to (1) a community water system,

(2) a transient noncommunity water system, such as a campground, or (3) a nontransient, noncommunity system, such as a school.

\section{$\mathbf{R}$}

recently recharged groundwater Groundwater that was recharged after 1952, as indicated by tritium concentrations greater than 0.5 tritium unit.

recharge The addition of water to the saturated zone naturally by precipitation or runoff or artificially by spreading or injection. Also, the water that is added.

reduction-oxidation (redox) Chemical reactions that involve the transfer of electrons from one chemical species to another, resulting in a change in the valence state of the species. Redox processes in groundwater often are microbially facilitated.

\section{S}

\section{Secondary Maximum Contaminant Level} (SMCL) Guidelines set by the U.S. Environmental Protection Agency for concentrations of "nuisance" constituents in drinking water that may cause unwanted effects, such as unpleasant taste, color, or odor; discoloration of skin or teeth; or corrosion or staining of plumbing fixtures. Public drinking-water systems are recommended but not required to comply with these guidelines.

semiconfined aquifer An aquifer (or part of an aquifer) that is partially covered by a confining layer. For the Upper Floridan aquifer, a semiconfined aquifer is defined as the part of the aquifer where the confining layer is less than 100 feet thick or is breached.

sinkhole Any closed depression in soil or bedrock formed by the erosion and transport of earth material from below the land surface.
A sinkhole typically has a closed topographic contour, drains to the subsurface, and occurs in karst terrane.

spring run A body of flowing water or stream that originates from a spring.

spring vent An opening that concentrates groundwater discharge at the Earth's surface.

Study Unit A major hydrologic system of the United States, geographically defined by surface- or groundwater features, in which U.S. Geological Survey National WaterQuality Assessment (NAWQA) Program sampling studies are focused.

swallow hole An opening or hole in bedrock into which a stream loses water or disappears underground.

\section{U}

unconfined aquifer An aquifer that has a water table; an aquifer containing unconfined groundwater.

\section{V}

volatile organic compound (VOC) An organic chemical that has a high vapor pressure relative to its water solubility. VOCs include components of gasoline, fuel oils, lubricants, organic solvents, fumigants, some inert ingredients in pesticides, and some by-products of chlorine disinfection.

vulnerability The tendency or likelihood for contaminants to reach a specified position in the groundwater system after introduction at some location above the uppermost aquifer. The vulnerability of a groundwater resource to contamination depends both on the intrinsic susceptibility of the resource and on the locations and types of human and geologic sources of contaminants, locations of wells, and the characteristics of the contaminant(s).

\section{W}

water table The upper surface of the saturated zone below which all voids (spaces) are filled with water. 


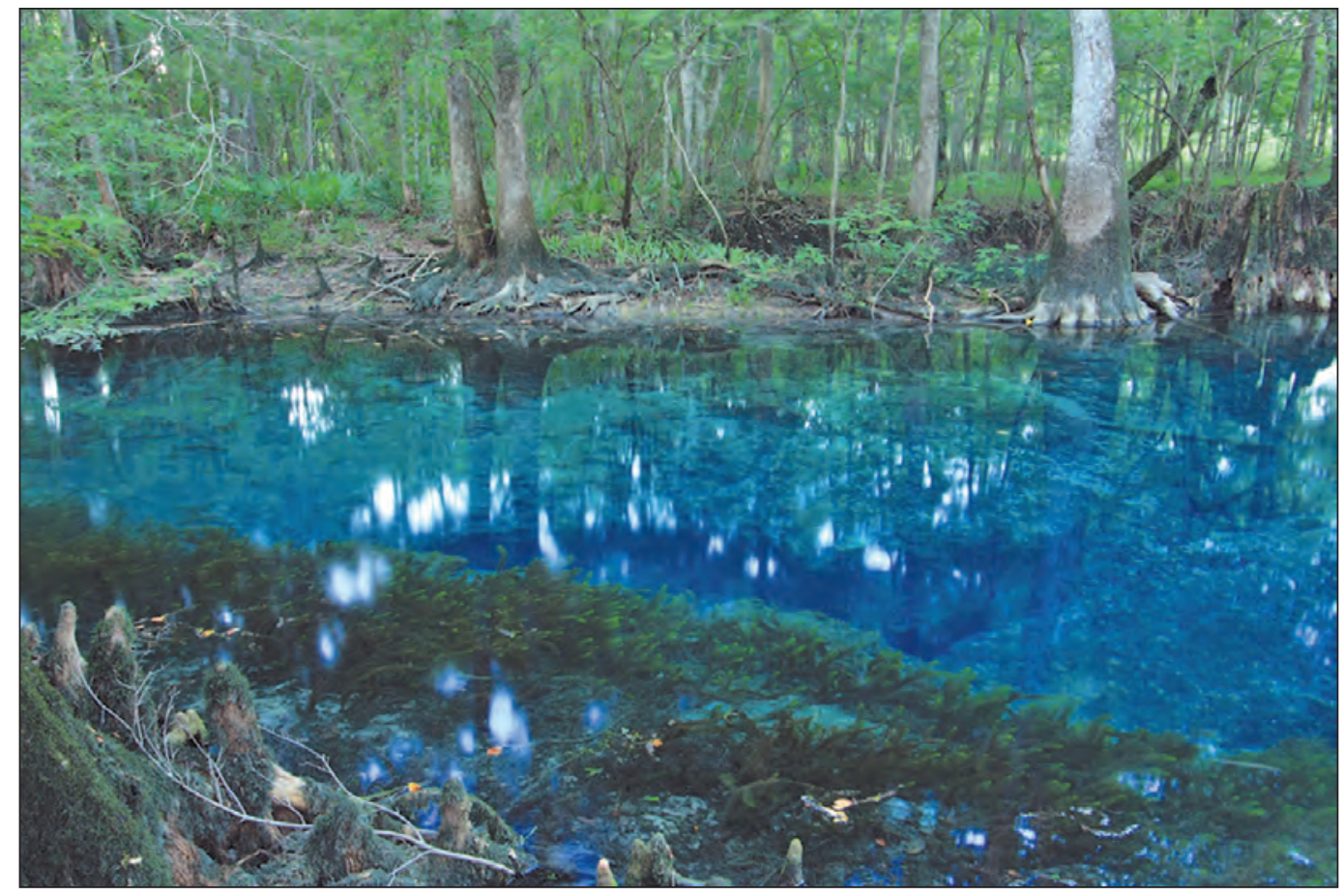

Baltzell Spring, no. 2, Jackson County, Florida. 


\section{Appendix 1. NAWQA Studies Design}

How does land use affect groundwater quality? How does water quality change as it moves through an aquifer? What is the quality of the drinking-water resource? NAWQA groundwater assessments include different types of studies, specifically designed to answer questions such as these.

- Land-use studies focus on sampling water from water-table monitoring wells installed in urban and agricultural areas to assess the effects of these land uses on the quality of the underlying groundwater. Although not typically used for drinking, this water supplies recharge to the deeper aquifer system.

- Flow-path studies investigate how water quality changes as it moves along a groundwater flow path. Samples were collected from wells installed along a groundwater flow path (http://pubs.usgs.gov/circ/circ1112/flowpath.htm).

- Major aquifer studies provide a broad overview of the quality of the deeper aquifer system used for drinking-water supply. Most of the wells sampled were domestic wells that were distributed across a large area in a mixture of land uses.

- Vulnerability studies are designed to assess the vulnerability of water delivered by public-supply wells to contamination from natural and manmade contaminants. Samples were collected from multiple depths in public-supply wells to determine where and how contaminants from different sources enter the wells and how natural processes and human activities affect water quality (http://oh.water.usgs.gov/tanc/NAWQATANC.htm).

- Source-water quality assessment studies focus on sampling water from public-supply wells to understand occurrence of unregulated manmade chemicals in the groundwater resources that serve large numbers of people (http://water.usgs.gov/nawqa/swqa).

Results of these studies were reinforced by locating some of the studies within the boundaries of larger studies. For example, the recharge areas for flow-path studies were located within the boundaries of the land-use studies to provide information on the quality of the recharge. In turn, the boundaries of the land-use studies were located within the boundaries of the major aquifer studies to provide information on how the quality of the recharge affects that of the deeper groundwater.

Each study involved sampling water from a network of a few to as many as 30 wells. Data from these studies were available for the Principal Aquifer assessments. 
Table A1-1. Study components of the Upper Floridan and surficial aquifers water-quality assessment.

[F, field parameters, including water temperature, specific conductance, $\mathrm{pH}$, alkalinity, turbidity, and dissolved oxygen; $\mathrm{M}$, major ions; $\mathrm{N}$, nutrients; $\mathrm{D}$, dissolved organic carbon; TE, trace elements; P, pesticide compounds; V, volatile organic compounds; R, radon; RA, radium; T, tritium; SI, stable isotopes of oxygen and hydrogen; A, age tracers other than tritium; MB, microbiological; AC, other anthropogenic organic compounds; TANC, Transport of Anthropogenic and Natural Contaminants study]

\begin{tabular}{|c|c|c|c|c|c|c|}
\hline $\begin{array}{c}\text { Study } \\
\text { component }\end{array}$ & Study location & Study purpose & $\begin{array}{c}\text { Water-quality } \\
\text { parameters } \\
\text { measured }\end{array}$ & $\begin{array}{c}\text { Year } \\
\text { sampled }\end{array}$ & $\begin{array}{l}\text { Number } \\
\text { of wells } \\
\text { sampled }\end{array}$ & Well types \\
\hline Major aquifer study & $\begin{array}{l}\text { Southwestern } \\
\text { Georgia }\end{array}$ & $\begin{array}{l}\text { Broadly characterize water } \\
\text { quality in the unconfined } \\
\text { Upper Floridan aquifer }\end{array}$ & $\begin{array}{l}\mathrm{F}, \mathrm{M}, \mathrm{N}, \mathrm{D}, \mathrm{TE}, \mathrm{P}, \\
\mathrm{V}, \mathrm{R},{ }^{*} \mathrm{~T}, * \mathrm{SI}, * \\
\mathrm{~A}, \dagger \mathrm{MB}, \dagger, \mathrm{RA}, \dagger\end{array}$ & $\begin{array}{l}1995 \\
2002\end{array}$ & 34 & $\begin{array}{l}\text { Mostly } \\
\text { domestic } \\
\text { wells }\end{array}$ \\
\hline $\begin{array}{l}\text { Major aquifer } \\
\text { study } !\end{array}$ & $\begin{array}{l}\text { Southwestern } \\
\text { Georgia }\end{array}$ & $\begin{array}{l}\text { Broadly characterize water quality } \\
\text { in springs in the unconfined } \\
\text { Upper Floridan aquifer }\end{array}$ & $\begin{array}{l}\mathrm{F}, \mathrm{M}, \mathrm{N}, \mathrm{D}, \mathrm{TE}, \mathrm{P} \\
\mathrm{V}, \mathrm{R},{ }^{*} \mathrm{~T}^{*}\end{array}$ & 1995 & 22 & Springs \\
\hline Major aquifer study & North-central Florida & $\begin{array}{l}\text { Broadly characterize water } \\
\text { quality in the unconfined } \\
\text { Upper Floridan aquifer }\end{array}$ & $\begin{array}{l}\mathrm{F}, \mathrm{M}, \mathrm{N}, \mathrm{D}, \mathrm{TE}, \mathrm{P} \\
\mathrm{V}, \mathrm{R},{ }^{*} \mathrm{~T}, * \mathrm{SI},{ }^{*} \\
\mathrm{MB}, \dagger \mathrm{RA} \uparrow\end{array}$ & 2002 & 30 & $\begin{array}{l}\text { Domestic } \\
\text { wells }\end{array}$ \\
\hline Major aquifer study & North-central Florida & $\begin{array}{l}\text { Broadly characterize water } \\
\text { quality in the semiconfined } \\
\text { Upper Floridan aquifer }\end{array}$ & $\begin{array}{c}\mathrm{F}, \mathrm{M}, \mathrm{N}, \mathrm{D}, \mathrm{TE}, \mathrm{P} \\
\mathrm{V}, \mathrm{R},{ }^{*} \mathrm{~T},{ }^{*} \mathrm{RA} \dagger\end{array}$ & 2002 & 30 & $\begin{array}{l}\text { Domestic } \\
\text { wells }\end{array}$ \\
\hline Major aquifer study & $\begin{array}{l}\text { Southwestern } \\
\text { Georgia }\end{array}$ & $\begin{array}{l}\text { Broadly characterize water } \\
\text { quality in the confined } \\
\text { Upper Floridan aquifer }\end{array}$ & $\begin{array}{l}\mathrm{F}, \mathrm{M}, \mathrm{N}, \mathrm{D}, \mathrm{TE} \\
\mathrm{P}, \mathrm{V}, \mathrm{R},{ }^{*} \mathrm{~T}, * \\
\mathrm{MB}, \dagger \mathrm{RA} \dagger\end{array}$ & 2005 & 30 & $\begin{array}{l}\text { Domestic } \\
\text { wells }\end{array}$ \\
\hline Major aquifer study & $\begin{array}{l}\text { Southern South } \\
\text { Carolina }\end{array}$ & $\begin{array}{l}\text { Broadly characterize water } \\
\text { quality in the semiconfined } \\
\text { Upper Floridan aquifer }\end{array}$ & $\begin{array}{l}\mathrm{F}, \mathrm{M}, \mathrm{N}, \mathrm{D}, \mathrm{TE}, \mathrm{P}, \\
\mathrm{V}, \mathrm{R},{ }^{*} \mathrm{~T},{ }^{*} \mathrm{~A}, \dagger \\
\mathrm{MB}, \dagger \mathrm{RA} \dagger\end{array}$ & $\begin{array}{l}1998 \\
2006\end{array}$ & 30 & $\begin{array}{l}\text { Domestic } \\
\text { wells }\end{array}$ \\
\hline Land-use study & $\begin{array}{l}\text { Southwestern } \\
\text { Georgia }\end{array}$ & $\begin{array}{l}\text { Characterize the quality of recently } \\
\text { recharged water in an agricultural } \\
\text { setting in the surficial aquifer (six } \\
\text { wells were in Upper Floridan aquifer) }\end{array}$ & $\begin{array}{c}\mathrm{F}, \mathrm{M}, \mathrm{N}, \mathrm{D}, \mathrm{TE}, \mathrm{P} \\
\quad \mathrm{V}, \mathrm{R}, \mathrm{T}, \mathrm{SI}, \mathrm{A}, \dagger\end{array}$ & $\begin{array}{c}1993 \\
2002-03\end{array}$ & 47 & $\begin{array}{l}\text { Monitoring } \\
\text { wells }\end{array}$ \\
\hline Land-use study & $\begin{array}{l}\text { South-central } \\
\text { Georgia }\end{array}$ & $\begin{array}{l}\text { Characterize the quality of recently } \\
\text { recharged water in an agricultural } \\
\text { setting in the surficial aquifer }\end{array}$ & $\begin{array}{l}\text { F, M, N, D, TE, P, } \\
\quad \text { V, R, T, SI }\end{array}$ & $\begin{array}{l}1994, \\
2002\end{array}$ & 31 & $\begin{array}{l}\text { Monitoring } \\
\text { wells }\end{array}$ \\
\hline Land-use study & $\begin{array}{l}\text { Southern South } \\
\text { Carolina }\end{array}$ & $\begin{array}{l}\text { Characterize the quality of recently } \\
\text { recharged water in an agricultural } \\
\text { setting in the surficial aquifer }\end{array}$ & $\begin{array}{l}\text { F, M, N, D, TE, P, } \\
\text { V, R, T, SI }\end{array}$ & $\begin{array}{l}1997 \\
2007\end{array}$ & 31 & $\begin{array}{l}\text { Monitoring } \\
\text { wells }\end{array}$ \\
\hline Land-use study & $\begin{array}{l}\text { Ocala and Tampa, } \\
\text { Florida }\end{array}$ & $\begin{array}{l}\text { Characterize the quality of recently } \\
\text { recharged water in an urban } \\
\text { setting in the surficial aquifer }\end{array}$ & $\begin{array}{l}\text { F, M, N, D, TE, P, } \\
\quad \text { V, R, T }\end{array}$ & $\begin{array}{l}1995 \\
2002\end{array}$ & 26 & $\begin{array}{l}\text { Monitoring } \\
\text { wells }\end{array}$ \\
\hline Land-use study & $\begin{array}{l}\text { Ocala and Tampa, } \\
\text { Florida }\end{array}$ & $\begin{array}{l}\text { Characterize the quality of recently } \\
\text { recharged water in an urban set- } \\
\text { ting in the Upper Floridan aquifer }\end{array}$ & $\begin{array}{l}\text { F, M, N, D, TE, P, } \\
\quad \text { V, R, T }\end{array}$ & $\begin{array}{l}1995 \\
2002\end{array}$ & 32 & $\begin{array}{l}\text { Monitoring } \\
\text { wells }\end{array}$ \\
\hline $\begin{array}{l}\text { Source-water } \\
\text { quality } \\
\text { assessment }\end{array}$ & Tampa, Florida area & $\begin{array}{l}\text { Characterize water quality in } \\
\text { public-supply wells in the uncon- } \\
\text { fined Upper Floridan aquifer }\end{array}$ & $\begin{array}{l}\mathrm{F}, \mathrm{M}, \mathrm{N}, \mathrm{D}, \mathrm{TE}, \mathrm{V} \\
\quad \mathrm{R}, \mathrm{RA}, \mathrm{T}, \mathrm{AC}\end{array}$ & 2002 & 15 & $\begin{array}{l}\text { Public- } \\
\text { supply } \\
\text { wells }\end{array}$ \\
\hline $\begin{array}{l}\text { Source-water } \\
\text { quality } \\
\text { assessment }\end{array}$ & Tampa, Florida area & $\begin{array}{l}\text { Characterize water quality in } \\
\text { public-supply wells in the semi- } \\
\text { confined Upper Floridan aquifer }\end{array}$ & $\begin{array}{l}\mathrm{F}, \mathrm{M}, \mathrm{N}, \mathrm{D}, \mathrm{TE}, \mathrm{V} \\
\quad \mathrm{R}, \mathrm{RA}, \mathrm{T}, \mathrm{AC}\end{array}$ & 2002 & 15 & $\begin{array}{l}\text { Public- } \\
\text { supply } \\
\text { wells }\end{array}$ \\
\hline $\begin{array}{l}\text { Transport of } \\
\text { anthropogenic } \\
\text { and natural } \\
\text { contaminants to } \\
\text { supply wells } \\
\text { (TANC study) } \$\end{array}$ & Tampa, Florida area & $\begin{array}{l}\text { Examine factors resulting in } \\
\text { detection of natural and } \\
\text { anthropogenic contaminants } \\
\text { in a public-supply well }\end{array}$ & $\begin{array}{c}\mathrm{F}, \mathrm{M}, \mathrm{N}, \mathrm{D}, \mathrm{P}, \mathrm{V}, \\
\mathrm{T}, \mathrm{A}, \mathrm{R}, \mathrm{SI}\end{array}$ & $2002-05$ & $\begin{array}{c}23: \\
11 \text { surficial } \\
\text { 12 Upper } \\
\text { Floridan }\end{array}$ & $\begin{array}{l}\text { Clusters of } \\
\text { monitor- } \\
\text { ing wells } \\
\text { along } \\
\text { transects }\end{array}$ \\
\hline
\end{tabular}

*Analyzed in samples collected during 1991-2001 only.

$\dagger$ Analyzed in samples collected during 2002-2009 only.

$\Varangle$ Samples from study not included in Principal Aquifers Summary Circular 1360 


\section{Appendix 2. Water-Quality Properties and Constituents Measured, a Summary of Data, and Complete Data Archive for 1993-2010}

Water-quality properties and constituents measured and a summary of data for 1993-2010, including laboratory reporting levels and human-health benchmarks for drinking water, are presented only online. The data summary and a complete data archive are available for download at http://pubs.usgs.gov/circ/1355/. 


\section{Appendix 3. Water Quality of the Upper Floridan Aquifer in a National Context}

\section{Principal Aquifer (number of samples)}

Wells of this type were not sampled for this constituent

U.S. Environmental Protection Agency contaminant levels for drinking water

- . - - MCL Maximum Contaminant Level

. - . - - SMCL Secondary Maximum Contaminant Level

- . - . - PMCL Proposed Maximum Contaminant Level

- - - - - AMcL Proposed Alternative Maximum Contaminant Level

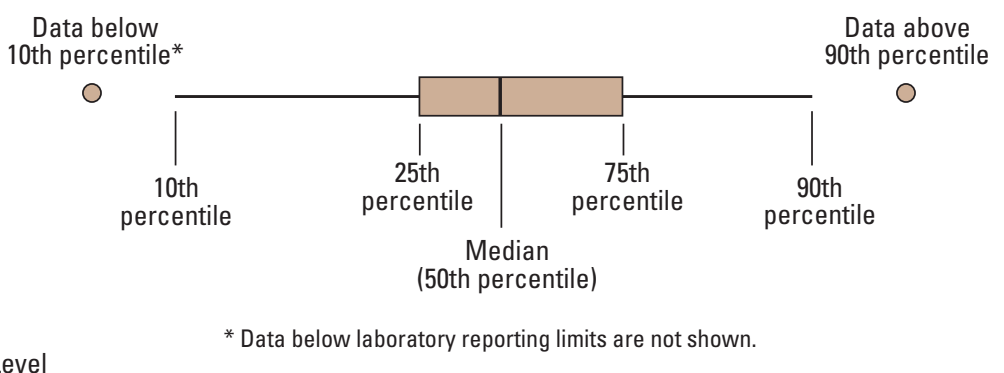

\section{Lithology}
Basalt and volcanics**
Crystalline
Carbonate
Sandstone
Semiconsolidated sand and gravel

Glacial unconsolidated sand and gravel

Unconsolidated sand and gravel (nonglacial)

This appendix shows graphical comparisons of chemical concentrations (1991 to 2010) for selected inorganic and organic constituents of potential health or aquatic-life concern in selected Principal Aquifers of the United States. For each constituent, the concentration data are grouped according to five well types: agricultural land-use study wells (includes shallow agricultural monitoring wells), urban land-use study wells (includes shallow urban monitoring wells), major aquifer study wells, domestic wells, and public-supply wells. For each well type, the aquifers also are grouped according to aquifer lithology: basalt and volcanics, ${ }^{* *}$ crystalline, carbonate, sandstone, semiconsolidated sand and gravel, glacial unconsolidated sand and gravel, and unconsolidated sand and gravel (nonglacial). Data for a particular compound were not plotted if there were fewer than 10 samples for a particular well network in a Principal Aquifer; not all Principal Aquifers for which data were available are shown. Note that analytical detection limits varied among the constituents and that the number of samples for a constituent can vary greatly between Principal Aquifers. The data used in this appendix and boxplots for additional constituents are available at http://pubs.usgs.gov/circ/1360/. ${ }^{(62)}$

** Note: Two of the Principal Aquifers in this group include limited samples from basin-fill aquifers within the extent of the basaltic aquifer. 


\section{Arsenic}

\section{Principal Aquifer}

Columbia Plateau basin fill-basalt rock (NA) Snake River Plain basin fill-basalt rock (54) Hawaiian volcanic (NA)

New England crystalline (107)

Piedmont and Blue Ridge crystalline (99)

Castle Hayne (6)

Upper Floridan (128)

Piedmont and Blue Ridge carbonate (NA)

Valley and Ridge carbonate (28)

Cambrian-Ordovician (69)

Denver Basin (75)

Early Mesozoic (24)

Valley and Ridge siliciclastic (27)

Mississippi embayment (27) Northern Atlantic Coastal Plain (60)

Texas coastal uplands (50) Glacial-East (68)

Glacial-Central (187)

Glacial-West Central (76) Glacial-West (23)

Basin and Range basin fill (129)

California Coastal Basin (18)

Central Valley (135)

Rio Grande (25)

Alluvial-Denver Basin (7)

Alluvial-Pleistocene terrace deposits (NA) High Plains (313)

Mississippi River Valley alluvial (5)

Surficial (30)

Columbia Plateau basin fill-basalt rock (22) Snake River Plain basin fill-basalt rock (NA) Hawaiian volcanic (25)

New England crystalline (1)

Piedmont and Blue Ridge crystalline (8) Castle Hayne (5)

Upper Floridan (35)

Piedmont and Blue Ridge carbonate (NA)

Valley and Ridge carbonate (NA) Cambrian-Ordovician (65)

Denver Basin (15)

Early Mesozoic (1)

Valley and Ridge siliciclastic (1)

Mississippi embayment (13)

Northern Atlantic Coastal Plain (5)

Texas coastal uplands (8)

Glacial-East (49)

Glacial-Central (31)

Glacial-West Central (15)

Glacial-West (11)

Basin and Range basin fill (101)

California Coastal Basin (94)

Central Valley (15)

Rio Grande (42)

Alluvial-Denver Basin (NA)

Alluvial-Pleistocene terrace deposits (NA)

High Plains (31)

Mississippi River Valley alluvial (12)

Surficial (NA)
Domestic wells

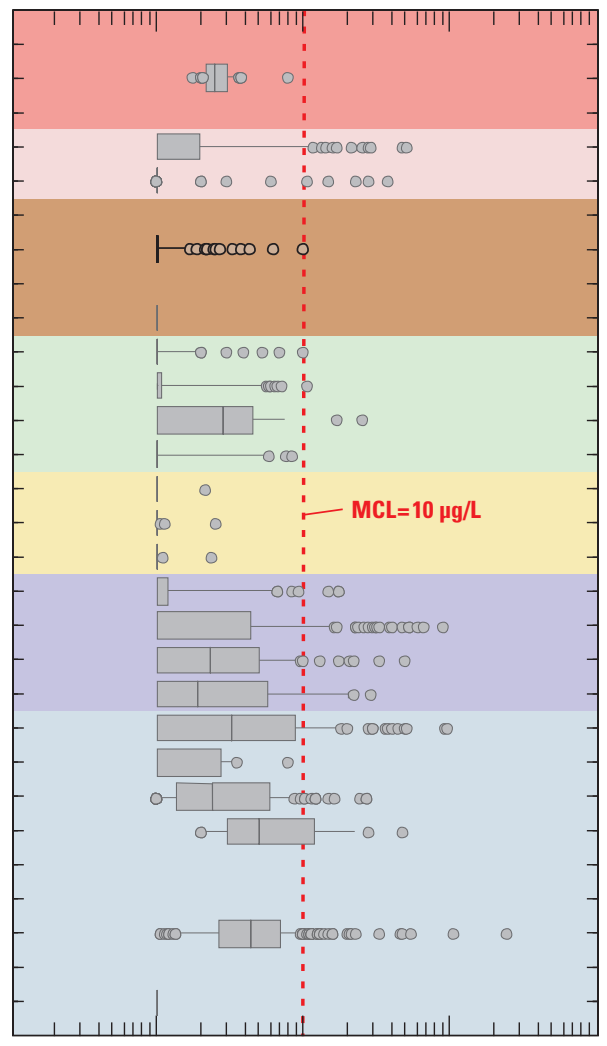

Public-supply wells

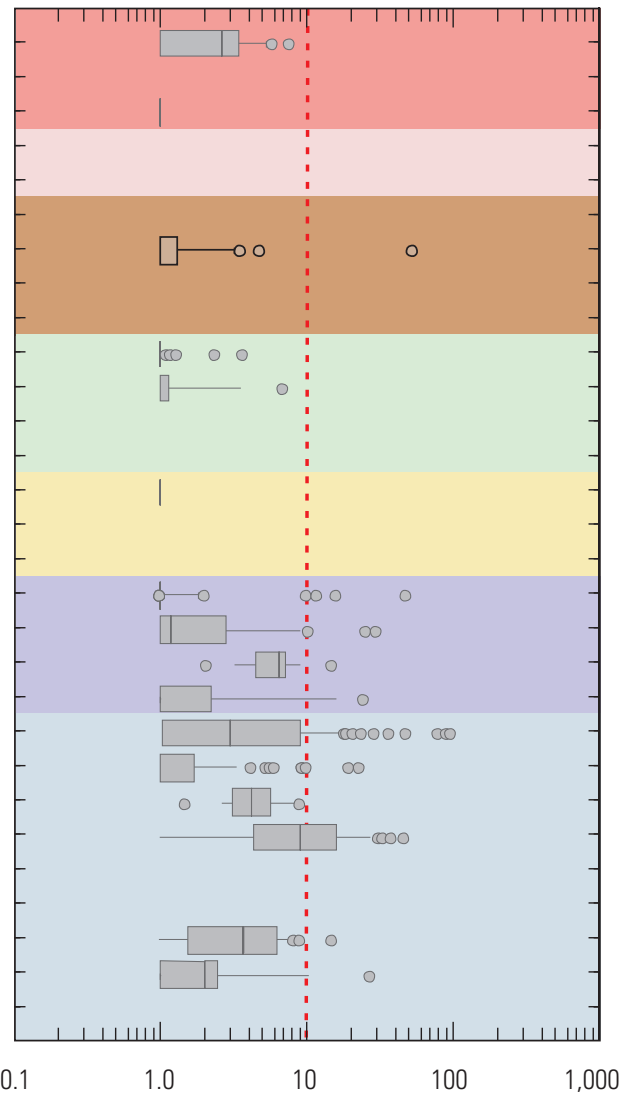

Arsenic concentration, in micrograms per liter 


\section{Atrazine}

Principal Aquifer

Columbia Plateau basin fill-basalt rock (63) Snake River Plain basin fill-basalt rock (149)

Hawaiian volcanic (NA)

New England crystalline (111)

Piedmont and Blue Ridge crystalline (151)

Castle Hayne (6)

Upper Floridan (124)

Piedmont and Blue Ridge carbonate (29)

Valley and Ridge carbonate (117)

Cambrian-Ordovician (72)

Denver Basin (55)

Early Mesozoic (68)

Valley and Ridge siliciclastic (81)

Mississippi embayment (27)

Northern Atlantic Coastal Plain (65)

Texas coastal uplands (49)

Glacial-East (99)

Glacial-Central (189)

Glacial-West Central (93)

Glacial-West (55)

California Coastal Basin (18)

Central Valley (138)

Rio Grande (24)

Alluvial-Denver Basin (7)

Alluvial-Pleistocene terrace deposits (NA)

High Plains (314)

Mississippi River Valley alluvial (5)

Surficial (30)
Basin and Range basin fill (131)

\section{Domestic wells}

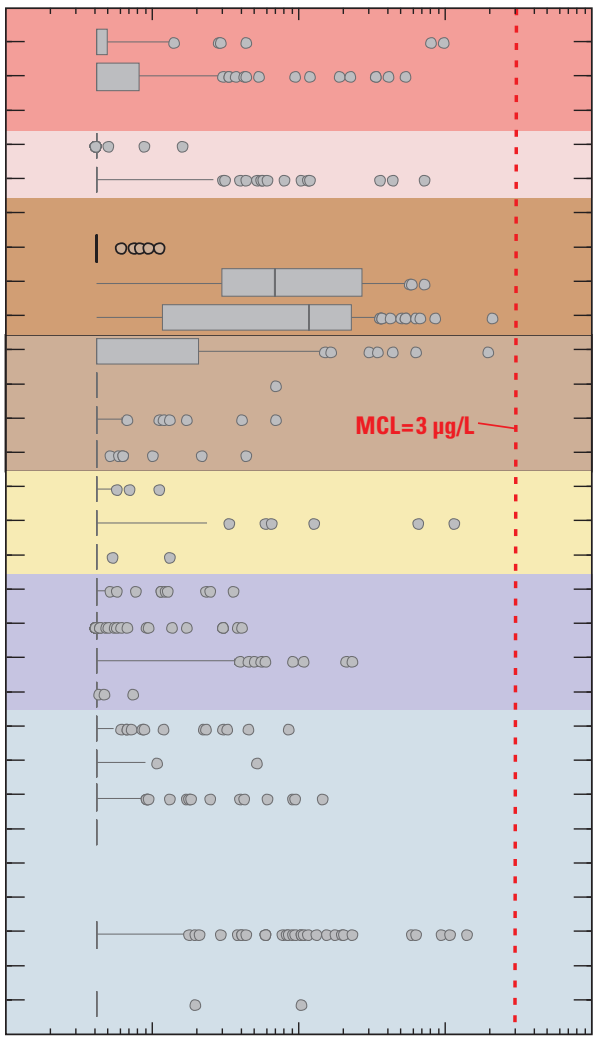

Public-supply wells

Columbia Plateau basin fill-basalt rock (34)

Snake River Plain basin fill-basalt rock (19)

Hawaiian volcanic (24)

New England crystalline (1)

Piedmont and Blue Ridge crystalline (23)

Castle Hayne (5)

Upper Floridan (35)

Piedmont and Blue Ridge carbonate (NA) Valley and Ridge carbonate (4)

Cambrian-Ordovician (81)

Denver Basin (15)

Early Mesozoic (2)

Valley and Ridge siliciclastic (1)

Mississippi embayment (55)

Northern Atlantic Coastal Plain (49)

Texas coastal uplands (8)

Glacial-East (68)

Glacial-Central (33)

Glacial-West Central (28)

Glacial-West (11)

Basin and Range basin fill (100)

California Coastal Basin (94)

Central Valley (15)

Rio Grande (40)

Alluvial-Denver Basin (NA)

Alluvial-Pleistocene terrace deposits (NA)

High Plains (31)

Mississippi River Valley alluvial (12)

Surficial (14)

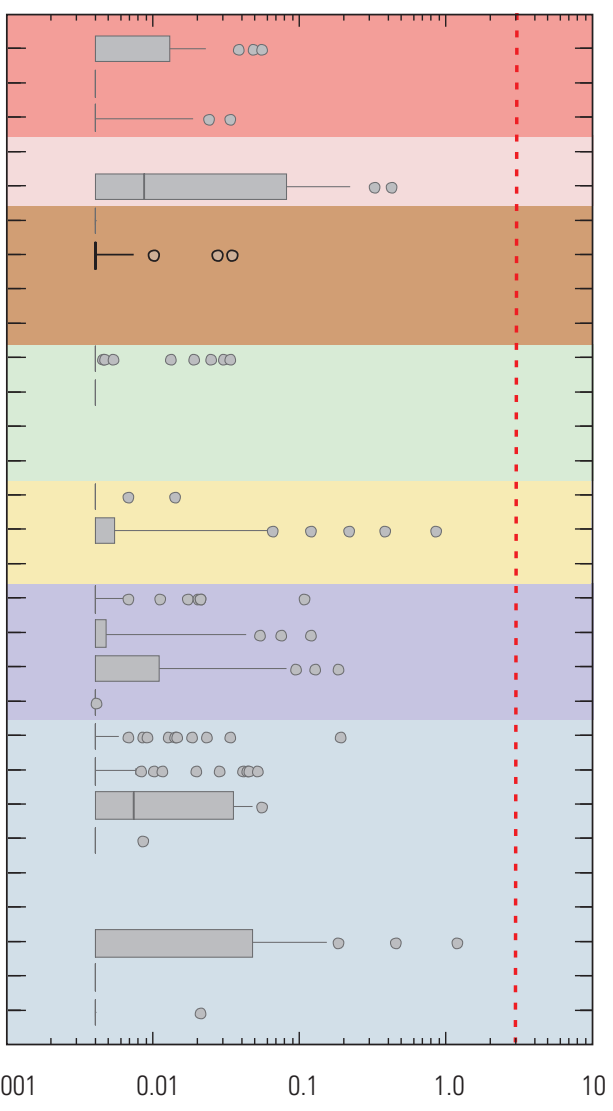

Atrazine concentration, in micrograms per liter 
Nitrate plus nitrite (nitrate)

\section{Principal Aquifer}

Columbia Plateau basin fill-basalt rock (63) Snake River Plain basin fill-basalt rock (151)

Hawaiian volcanic (NA) New England crystalline (113)

Piedmont and Blue Ridge crystalline (151)

Castle Hayne (6)

Upper Floridan (127)

Piedmont and Blue Ridge carbonate (29) Valley and Ridge carbonate (116)

Cambrian-Ordovician (71) Denver Basin (75)

Early Mesozoic (69)

Valley and Ridge siliciclastic (81)

Mississippi embayment (27)

Northern Atlantic Coastal Plain (66)

Texas coastal uplands (50)

Glacial-East (97)

Glacial-Central (210)

Glacial-West Central (96)

Glacial-West (55)

Basin and Range basin fill (123)

California Coastal Basin (18) Central Valley (137)

Rio Grande (25)

Alluvial-Denver Basin (7)

Alluvial-Pleistocene terrace deposits (NA)

High Plains (314)

Mississippi River Valley alluvial (5)

Surficial (30)

Columbia Plateau basin fill-basalt rock (34) Snake River Plain basin fill-basalt rock (19)

Hawaiian volcanic (25)

New England crystalline (1)

Piedmont and Blue Ridge crystalline (8)

Castle Hayne (5)

Upper Floridan (34)

Piedmont and Blue Ridge carbonate (NA)

Valley and Ridge carbonate (4)

Cambrian-Ordovician (80)

Denver Basin (15)

Early Mesozoic (2)

Valley and Ridge siliciclastic (1)

Mississippi embayment (41)

Northern Atlantic Coastal Plain (35)

Texas coastal uplands (8)

Glacial-East (49)

Glacial-Central (37)

Glacial-West Central (28

Glacial-West (11)

Basin and Range basin fill (101)

California Coastal Basin (93)

Central Valley (15)

Rio Grande (42)

Alluvial-Denver Basin (NA)

Alluvial-Pleistocene terrace deposits (NA)

High Plains (31)

Mississippi River Valley alluvial (12) Surficial (NA)
Domestic wells

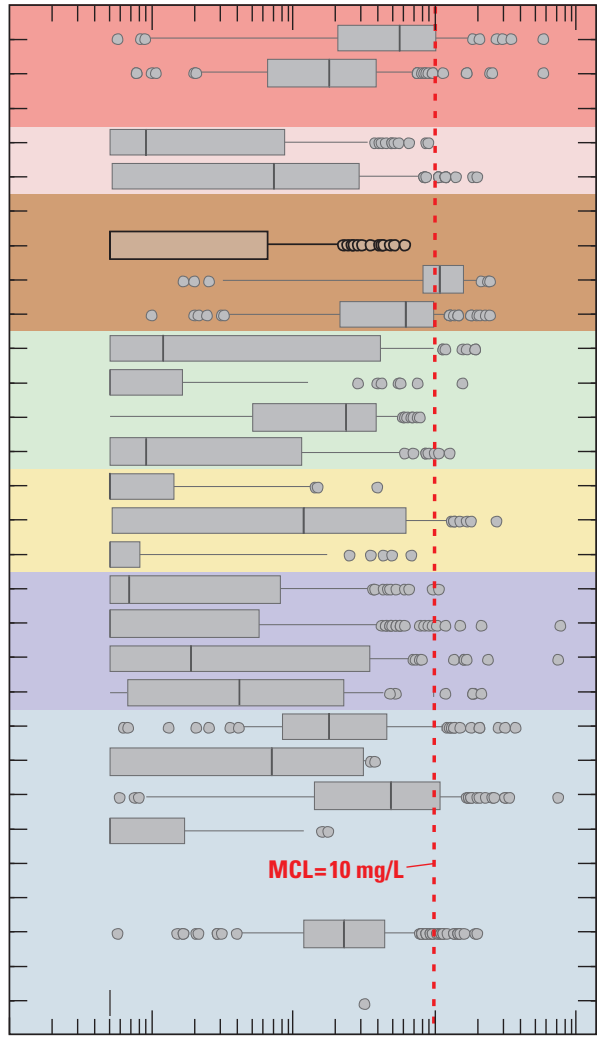

Public-supply wells

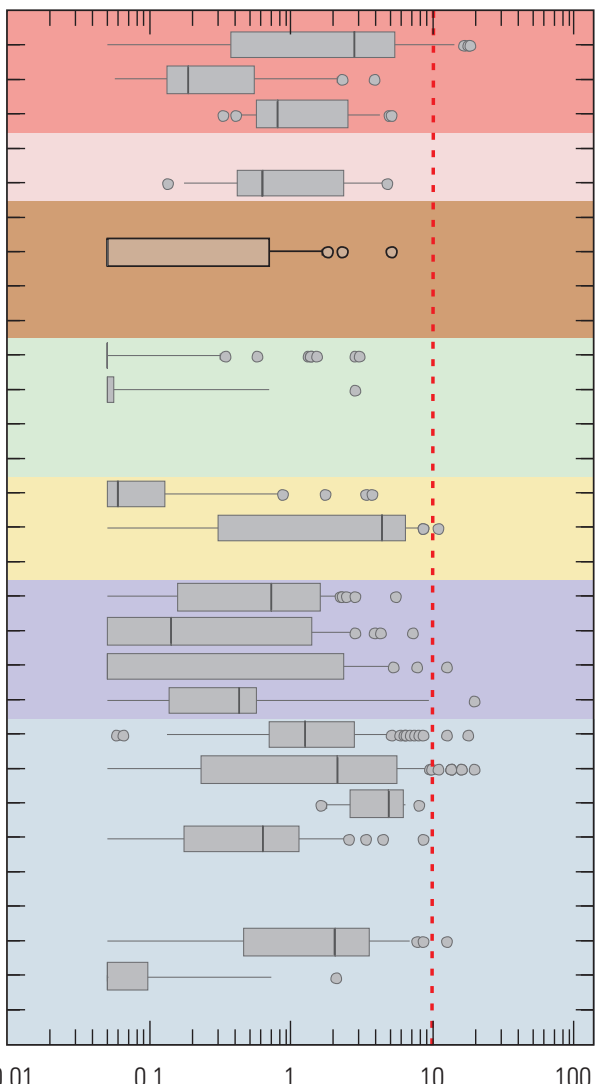

100

Nitrate concentration, in milligrams per liter as nitrogen 


\section{Radon}

\section{Principal Aquifer}

Columbia Plateau basin fill-basalt rock (59) Snake River Plain basin fill-basalt rock (115 Hawaiian volcanic (NA) New England crystalline (109)

Piedmont and Blue Ridge crystalline (150) Castle Hayne (6)

Upper Floridan (88)

Piedmont and Blue Ridge carbonate (29) Valley and Ridge carbonate (112)

Cambrian-Ordovician (47) Denver Basin (55)

Early Mesozoic (48)

Valley and Ridge siliciclastic (79

Mississippi embayment (17)

Northern Atlantic Coastal Plain (55)

Texas coastal uplands $(40)$

Glacial-East (97)

Glacial-Central (153)

Glacial-West Central (58) Glacial-West (48)

Basin and Range basin fill (112

California Coastal Basin (17) Central Valley (111)

Rio Grande (24)

Alluvial-Denver Basin (6)

Alluvial-Pleistocene terrace deposits (NA

High Plains (307)

Mississippi River Valley alluvial (5)

Surficial (30)
Domestic wells

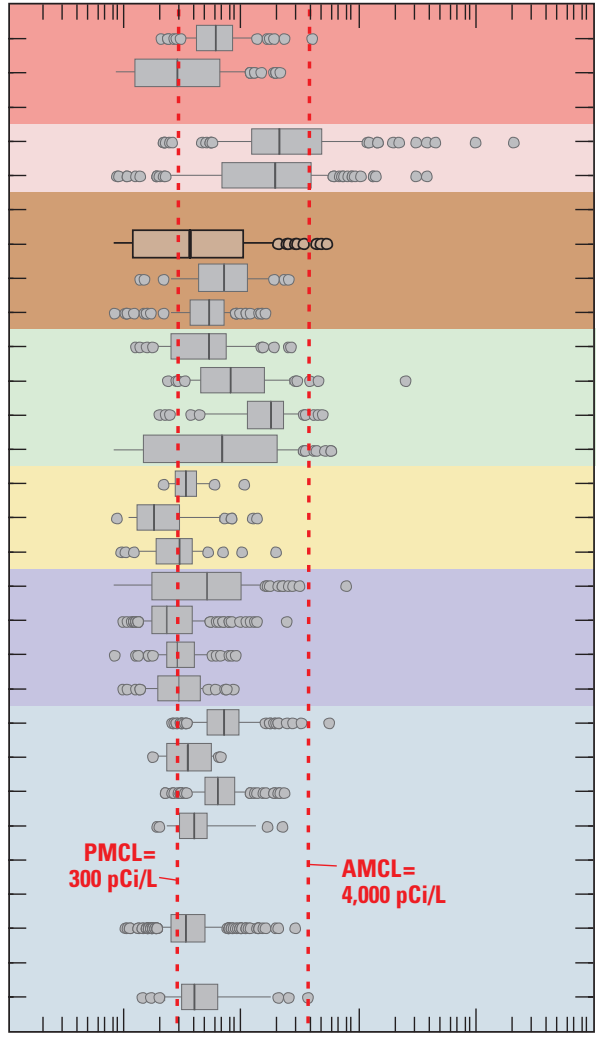

10

1,000

10,000

$100,000 \quad 1,000,000$

Radon concentration, in picocuries per liter 
Prepared by the USGS Science Publishing Network Raleigh Publishing Service Center

Edited by Kay P. Naugle

Illustrations and layout by Caryl J. Wipperfurth

For more information concerning this report, contact: Chief, National Water-Quality Assessment Program U.S. Geological Survey

413 National Center

12201 Sunrise Valley Drive

Reston, VA 20192

http://water.usgs.gov/nawqa/ 


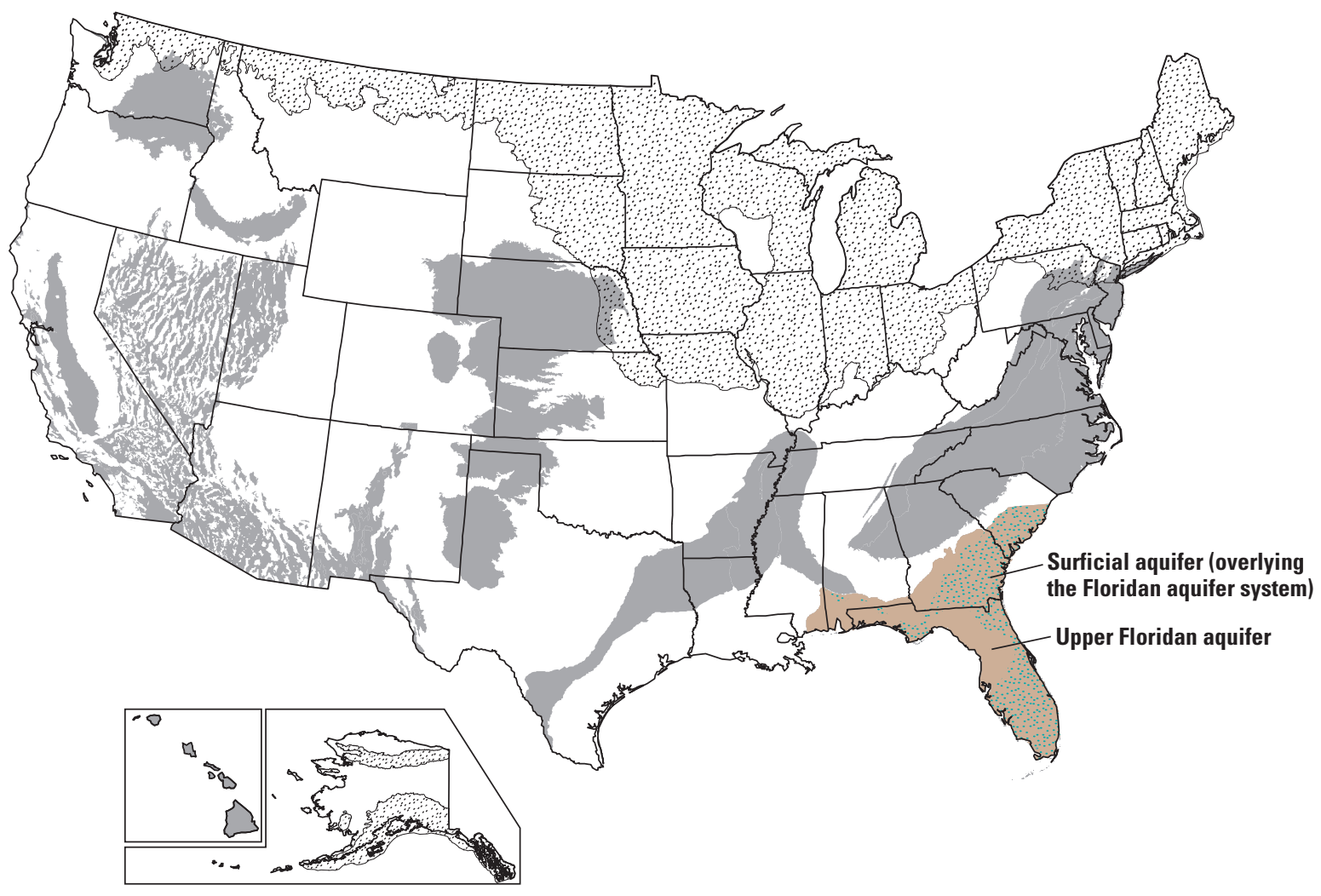

ISSN 1067-084X (print) 